

\section{AVAILABILITY OF BOOKS AND MAPS OF THE U.S. GEOLOGICAL SURVEY}

Instructions on ordering publications of the U.S. Geological Survey, along with the last offerings, are given in the current-year issues of the monthly catalog “New Publications of the U.S. Geological Survey.” Prices of available U.S. Geological Survey publications released prior to the current year are listed in the most recent annual "Price and Availability List." Publications that are listed in various U.S. Geological Survey catalogs (see back inside cover) but not listed in the most recent annual "Price and Availability List" are no longer available.

Prices of reports released to the open files are given in the listing "U.S. Geological Survey Open-File Reports," updated monthly, which is for sale in microfiche from the U.S. Geological Survey Books and Open-File Reports Sales, Box 25425, Denver, CO 80225.

Order U.S. Geological Survey publications by mail or over the counter from the offices given below.

\section{BY MAIL}

\section{Books}

Professional Papers, Bulletins, Water-Supply Papers, Techniques of Water-Resources Investigations, Circulars, publications of general interest (such as leaflets, pamphlets, booklets), single copies of periodicals (Earthquakes \& Volcanoes, Preliminary Determination of Epicenters), and some miscellaneous reports, including some of the foregoing series that have gone out of print at the Superintendent of Documents, are obtainable by mail from

\section{U.S. Geological Survey, Books and Open-File Report Sales Box 25425 \\ Denver, CO 80225}

Subscriptions to periodicals (Earthquakes \& Volcanoes and Preliminary Determination of Epicenters) can be obtained ONLY from

\section{Superintendent of Documents}

U.S. Government Printing Office

Washington, DC 20402

(Check or money order must be payable to Superintendent of Documents.)

\section{Maps}

For maps, address mail order to

U.S. Geological Survey, Map Sales Box 25286

Denver, CO 80225

Residents of Alaska may order maps from

\author{
U.S. Geological Survey, Map Sales \\ 101 Twelfth Ave., Box 12 \\ Fairbanks, AK 99701
}

\section{OVER THE COUNTER}

\section{Books}

Books of the U.S. Geological Survey are available over the counter at the following U.S. Geological Survey offices, all of which are authorized agents of the Superintendent of Documents.

- ANCHORAGE, Alaska-4230 University Dr., Rm. 101

- ANCHORAGE, Alaska-605 West 4th Ave., Rm G-84

- DENVER, Colorado-Federal Bldg., Rm. 169, 1961 Stout St.

- LAKEWOOD, Colorado-Federal Center, Bldg. 810

- MENLO PARK, California-BIdg. 3, Rm. 3128, 345 Middlefield Rd.

- RESTON, Virginia-National Center, Rm. 1C402, 12201 Sunrise Valley Dr.

- SALT LAKE CITY, Utah-Federal Bldg., Rm. 8105, 125 South State St.

- SAN FRANCISCO, California-Customhouse, Rm. 504, 555 Battery St.

- SPOKANE, Washington-U.S. Courthouse, Rm. 678, West 920 Riverside Ave.

- WASHINGTON, D.C.-U.S. Department of the Interior BIdg., Rm. 2650, 1849 C St., NW.

\section{Maps}

Maps may be purchased over the counter at the U.S. Geological Survey offices where books are sold (all addresses in above list) and at the following Geological Survey offices:

- ROLLA, Missouri-1400 Independence Rd.

- FAIRBANKS, Alaska-New Federal Building, 101 Twelfth Ave. 
Chapter J

\title{
Depositional History of Jurassic Rocks in the Area of the Powder River Basin, \\ Northeastern Wyoming and \\ Southeastern Montana
}

\author{
By EDWARD A. JOHNSON
}

A multidisciplinary approach to research studies of sedimentary rocks and their constituents and the evolution of sedimentary basins, both ancient and modern 


\section{U.S. DEPARTMENT OF THE INTERIOR MANUEL LUJAN, JR., Secretary}

\section{U.S. GEOLOGICAL SURVEY}

Dallas L. Peck, Director

For sale by

Book and Open-File Report Sales

U.S. Geological Survey

Federal Center, Box 25425

Denver, CO 80225

\section{Library of Congress Cataloging-in-Publication Data}

Johnson, Edward A. (Edward Allison), 1940-

Depositional history of Jurassic rocks in the area of the Powder River Basin, northeastern Wyoming and southeastern Montana / by Edward A. Johnson. p. cm.-(Evolution of sedimentary basins-Powder River Basin; ch. J) (U.S. Geological Survey bulletin ; 1917-J) Includes bibliographical references.

1. Geology, Stratigraphic-Jurassic. 2. Sedimentation and depositionPowder River Basin (Wyo. and Mont.) 3. Rocks, Sedimentary-Powder River Basin (Wyo. and Mont.). I. Title. II. Series. III. Series: U.S. Geological Survey bulletin ; 1917-J.

QE75.B9 no. 1917-J

[QE681]

$557.3 \mathrm{~s}-\mathrm{dc} 20$

[551.7'66'09787] 


\section{CONTENTS}

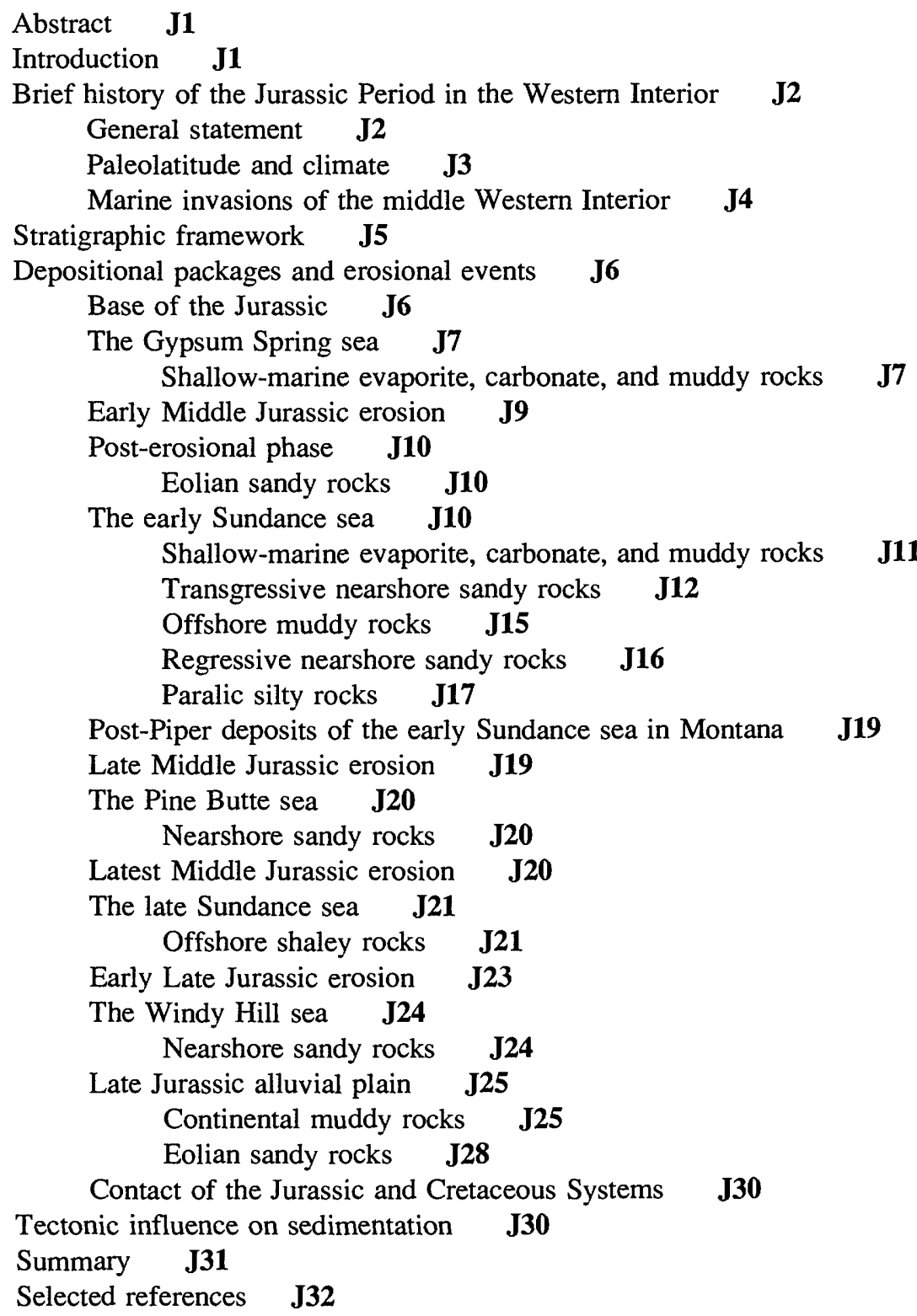

\section{FIGURES}

1-4. Maps showing:

1. Location of Powder River Basin J2

2. Positions of continents during the earliest Jurassic and Middle Jurassic J2

3. Relation between Powder River Basin and Jurassic tectonic elements in western North America J3

4. Jurassic tectonic elements in vicinity of Powder River Basin 
5. Chart showing stratigraphy of Jurassic rocks in vicinity of Powder River Basin J5

6. Generalized north-south cross section of Jurassic rocks in vicinity of Powder River Basin J6

7. Map showing maximum areal extent of Bajocian Gypsum Spring sea in Western Interior $\mathbf{J 7}$

8. Photograph showing limestone unit in Gypsum Spring Formation J8

9-11. Maps showing:

9. Maximum areal extent of Poe Evaporite Member of the Nesson Formation J9

10. Areal extent of Bathonian-Callovian early Sundance sea in Western Interior $\mathbf{J 1 1}$

11. Isopachs of lower part of Sundance Formation in Wyoming part of Powder River Basin J11

12. Photograph showing flatbedded sandstone facies in Canyon Springs Member of the Sundance Formation J13

13. Map showing effects of shoaling in vicinity of Sheridan Arch on distribution of bivalves and ostracodes in early Sundance sea $\mathbf{J 1 6}$

14. Photograph showing Hulett Sandstone Member of the Sundance Formation J16

15. Map showing northern extent of Lak Member of the Sundance Formation $\mathbf{J 1 8}$

16. Photograph showing Pine Butte Member of the Sundance Formation J20

17-20. Maps showing:

17. Maximum areal extent of Oxfordian late Sundance sea in Western Interior $\mathbf{J} 21$

18. Isopachs of upper part of the Sundance Formation in Wyoming part of Powder River Basin J22

19. Isopachs of Morrison Formation in Wyoming part of Powder River Basin J27

20. Maximum areal extent of Morrison foreland basin in Western Interior $\mathbf{J} 28$

21. Photograph showing eolian facies in lower part of the Morrison Formation J29 


\title{
Depositional History of Jurassic Rocks in the Area of the Powder River Basin, Northeastern Wyoming and Southeastern Montana
}

\author{
By Edward A. Johnson
}

\begin{abstract}
During the Jurassic, a complex active margin existed along the western edge of the North American plate. The topographically positive Western Cordillera bounded this margin on the east, forming the western side of the topographically lower Western Interior, and the central part of the North American craton was exposed east of the Western Interior.

Lower Jurassic rocks are not present in the area that is now the Powder River Basin; they were either eroded away or never deposited. During the Middle through early Late Jurassic, the middle Western Interior intermittently contained a large epeiric seaway composed of a deep retro-arc basin on the west and a shallow marine shelf on the east. In the area of the Powder River Basin, five marine events resulted in a complex sequence of craton-wedge deposits separated by surfaces of erosion. Southern and eastern source areas contributed sediments to the seaway during the first through third events, but uplift of the Cordillera during the Late Jurassic provided a western source for the fourth and possibly fifth marine events and for the nonmarine deposition that followed.

The first marine event occurred during the early Middle Jurassic when marine water transgressed into the northern and central parts of the Powder River Basin. After depositing a sequence of red beds, evaporites, and shallow-water carbonate rocks, this sea retreated from the middle Western Interior and a period of erosion followed. The second marine event occurred during the middle and late Middle Jurassic. A shallow-marine sandy facies was deposited over a wide area when the marine transgression redistributed eolian sand that had accumulated on the erosion surface. The transgressionregression reversal is recorded in an overlying deeper water argillaceous facies, which itself is overlain by a regressive shoreface sandy facies. Overlying the shoreface deposits in the
\end{abstract}

Manuscript approved for publication September 9, 1991. southern part of the Powder River Basin is a unit of red beds of shallow-marine or nonmarine(?) origin. The third marine event is recorded in a thin marine sandstone that was deposited following a rapid transgression just prior to a major retreat of marine water from the middle Western Interior and the development of a regional erosion surface. The fourth marine event occurred during the early Late Jurassic when marine water transgressed across the erosion surface depositing a thick sequence of argillaceous sediment. Following regression and a period of erosion a fifth and final transgression resulted in a thin marine sandstone.

Soon after the final retreat of the epeiric seaway, nonmarine sediments prograded eastward from the recently uplifted tectonic lands to the west, and fluvial and lacustrine deposits accumulated over a wide area of the Western Interior. The passage from the Jurassic to Cretaceous is marked by a sequence of nonconnected erosional surfaces and a subtle change in both the composition and depositional style of fluvial units.

\section{INTRODUCTION}

The area of the Powder River Basin covers parts of northeastern Wyoming, western South Dakota, and southeastern Montana (fig. 1). As outlined by the contact of Cretaceous and Tertiary strata, the basin covers approximately $22,000 \mathrm{mi}^{2}$. The basin is bordered by basementcored uplifts on three sides: the Bighorn Mountains on the west, the Laramie Range and the Hartville Uplift on the south, and the Black Hills on the east. To the north, the basin is separated from the eastern Montana part of the Williston Basin by a northwest-trending positive element on the Precambrian basement known as the Miles City Arch. Rocks of Jurassic age are exposed in all of the surrounding uplifts. The Powder River Basin lies on the eastern edge of the Laramide structural province. This basin and other 
similar basins in the Rocky Mountain foreland formed mostly during the early Tertiary.

\section{BRIEF HISTORY OF THE JURASSIC PERIOD IN THE WESTERN INTERIOR}

\section{General Statement}

During the earliest Jurassic, North America was part of a much larger supercontinent named Pangea (fig. 2). In the later part of the Period, Europe and Africa separated from Pangea creating the North American plate. By the Middle Jurassic, an incipient Atlantic Ocean and Gulf of Mexico had developed adjacent to the passive eastern and southeastern margins of the North American plate. At the same time, a complex active margin developed along the western edge of the plate (fig. 3) as the North American plate interacted with the adjacent Farallon plate. The tectonic setting of the western part of North America was determined by the relative motion of these two plates. Today, the thickest section of Jurassic rocks in North America is along the Pacific coast where as much as $25,000 \mathrm{ft}$ of intercalated graywacke, shale, radiolarian chert, and basalt flows accumulated along this active margin.

East of the western plate boundary, a 400-mile-wide area of positive relief-the North American Cordilleraseparated the active margin from the North American

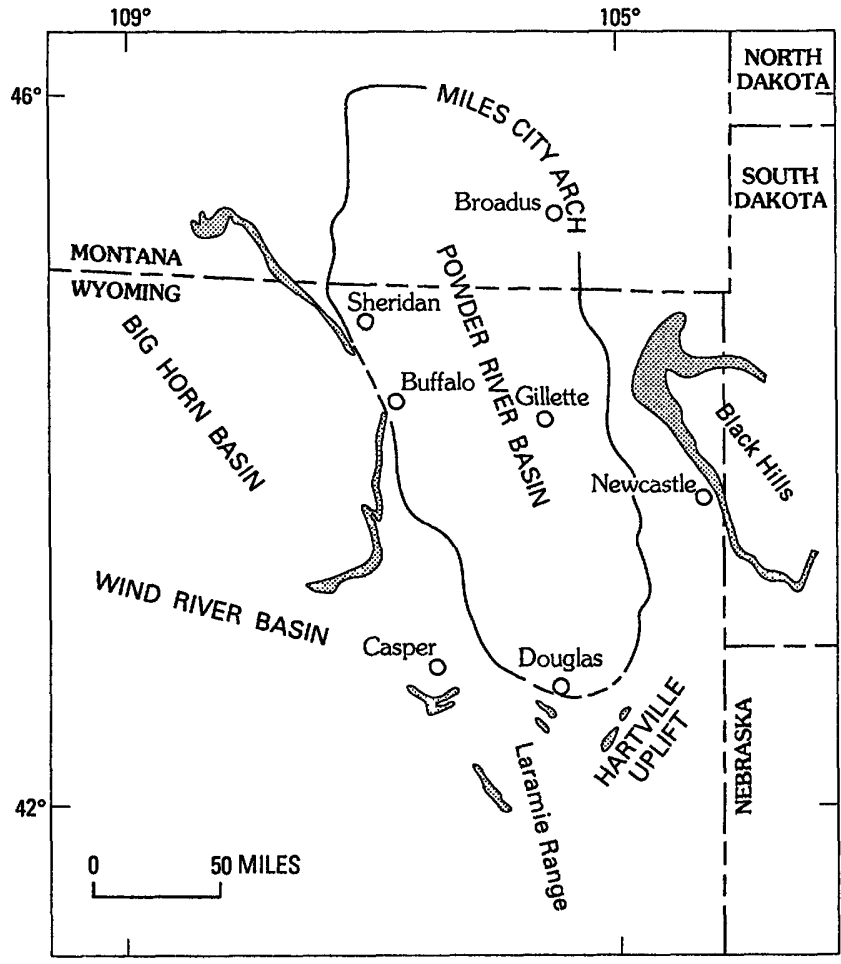

Figure 1. Location of Powder River Basin (shown by outline). Outcrops of Jurassic rocks shown by screened pattern.

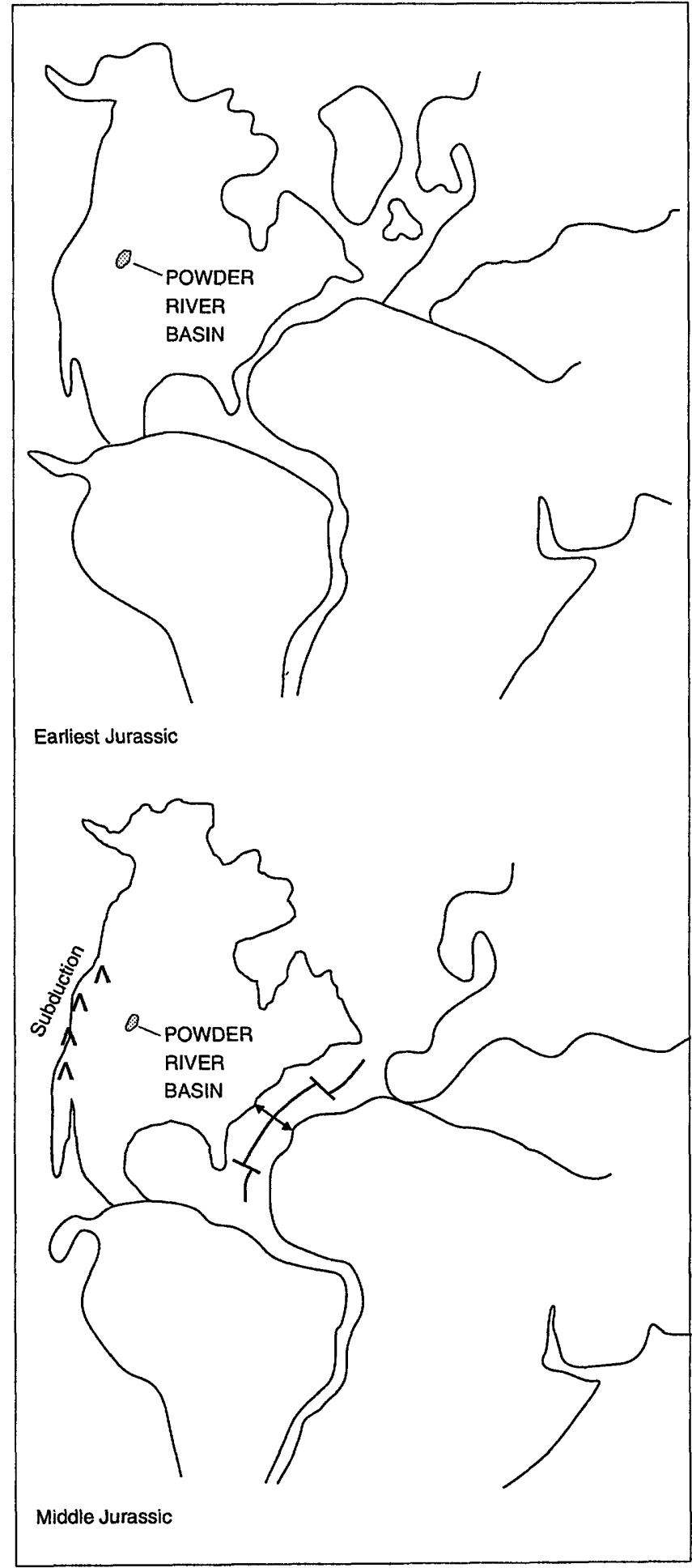

Figure 2. Approximate positions of continents during the earliest Jurassic and Middle Jurassic. Modified from Smith and Briden (1977).

Western Interior. During the Early and Middle Jurassic, the Cordillera was probably a land mass of relatively low relief. The main part of the stable North American craton was exposed east of the Western Interior. 


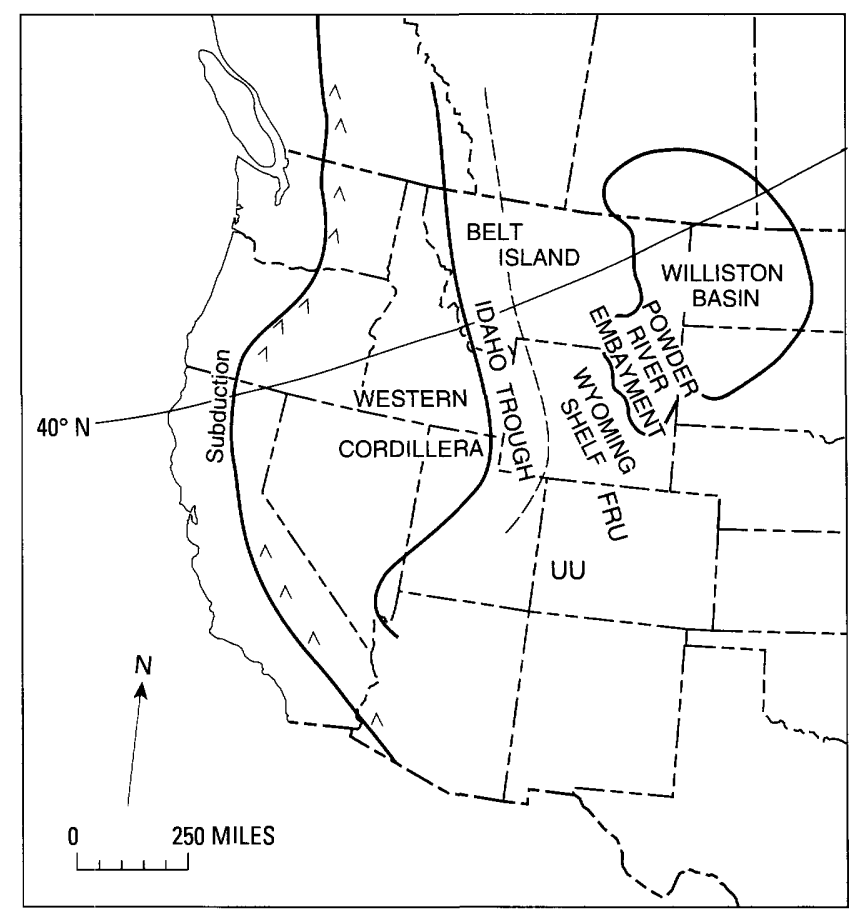

Figure 3. Relation between Powder River Basin and Jurassic tectonic elements in western North America. FRU, Front Range Uplift; UU, Uncompaghre Uplift. Modified from Shurr and others (1989). Location of Jurassic paleolatitude of $40^{\circ} \mathrm{N}$. is also shown.

More than 3,000 ft (Imlay, 1980) of eolian and minor fluvial sediment accumulated in the southern part of the Western Interior during the Early Jurassic (for example, Glen Canyon Group). In the east-middle part of the Western Interior similar sediments might have been deposited, but early Middle Jurassic erosion cut down into Triassic rocks and removed any evidence of possible Early Jurassic deposits. It is more likely that this area was a region of nondeposition and perhaps even a source of sediments (F. Peterson, U.S. Geological Survey, oral commun., 1990).

At the beginning of the Middle Jurassic, marine water from the west and north invaded parts of the middle Western Interior. The event initiated the irregularly shaped Jurassic Western Interior seaway (also known as the Jurassic embayment) that existed intermittently into the latter part of the period. A discontinuous landmass bordered this 800-mile-wide epeiric seaway on the west and limited access to the open-marine environment of the ancestral Pacific Ocean. The asymmetrical seaway had a relatively deep retro-arc basin on its western side named the Idaho or Twin Creek Trough that occupied north-central Utah, western Wyoming, southeastern Idaho, and western Montana. The shallower eastern side of the seaway contained a marine shelf in eastern Wyoming and a wide, symmetrical, intracratonic basin in eastern Montana and western North Dakota (Williston Basin). The tectonic stability of the eastern middle Western Interior is indicated by (1) lack of coarse clastic rocks, (2) great lateral persistence of stratigraphic units, (3) lack of volcanogenic sedimentary rocks, and (4) absence of significantly angular relations at unconformities. No modern analog for the Jurassic Western Interior seaway exists. Middle to Upper Jurassic marine rocks deposited in the Idaho Trough consist mostly of carbonates and are as thick as $8,000 \mathrm{ft}$ (J.A. Peterson, 1988). Marine rocks representing the same time span deposited to the east on the shelf are mostly siliciclastic craton-wedge deposits and are typically about $800 \mathrm{ft}$ thick (Imlay, 1957). Marine carbonate rocks had accumulated intermittently on the western passive margin of Pangea since the beginning of the Phanerozoic. The carbonate rocks that accumulated on the western side of the Jurassic Western Interior seaway represent the final phase of carbonate deposition in the Rocky Mountain region. Siliciclastic deposition occurred mostly on the shelf on the eastern side of the seaway. As demonstrated by an increase in sand content to the south and east, the eastern side of the seaway received sediment from the Ancestral Rockies and from the craton.

During the Late Jurassic Nevada orogeny, extensive mountain building occurred along the Cordillera. Thus, for the first time in Phanerozoic history, a sizeable area on the western side of North America became a significant source of sediment for epeiric seas farther to the east in the Western Interior. The carbonate deposition that dominated the western side of the Jurassic Western Interior seaway gave way to siliciclastic deposition. Sand in these deposits increases to the west and probably was derived from the Cordillera.

During the Late Jurassic, marine water withdrew from the Western Interior, probably due to a combination of (1) increased progradation of siliciclastic sediments from the western source area, (2) reduced subsidence in the seaway, and (3) eustatic lowering of sea level. Following the withdrawal, nonmarine sediments prograded from west to east across the exposed sea floor depositing several hundred feet of continental rocks now represented in the uppermost part of the Jurassic section.

\section{Paleolatitude and Climate}

Climatic conditions during the Mesozoic were warm and dry; the global mean temperature was perhaps as much as $18^{\circ} \mathrm{F}$ higher than today (Kocurek and Dott, 1983). All through the Jurassic, the North American plate drifted northward with some clockwise rotation (Kocurek and Dott, 1983). The middle Western Interior migrated approximately through lat $22^{\circ}$ to $42^{\circ} \mathrm{N}$. (lat. $25^{\circ}-36^{\circ} \mathrm{N}$. for the area of the Powder River Basin) (Parrish and Peterson, 1988). The northward drift probably moved the middle part of the Western Interior into progressively more humid climates as the period drew to a close. 


\section{Marine Invasions of the} Middle Western Interior

During at least part of the Early Jurassic, marine water was present along the western margin of the United States and in the northern Western Interior of Canada. Evidently this water did not reach the Western Interior of the United States because no Lower Jurassic marine rocks are in this area. Instead, the Early Jurassic is represented by either nonmarine deposits or nondeposition (J-1 unconformity).

At the beginning of the early Middle Jurassic, marine water from the west and north spread over much of the middle Western Interior. This event was the first of five marine inundations of the relatively shallow eastern side of the seaway. Each event consists of one transgressiveregressive cycle. In the area of the Powder River Basin, the last four events are commonly referred to collectively as the Sundance sea. Three of these events, probably representing eustasy, are easily recognized on the proposed Jurassic sea-level curve of Hallam (1988) and formed distinct phases of the Jurassic seaway in the area of the Powder River Basin; two of these events included shorter, possibly tectonically controlled regressive-transgressive episodes. The Jurassic Western Interior seaway was referred to by Peterson (1958) as the "great transgressor" because of complicated history of transgressions and regressions. Overall, the Jurassic Western Interior seaway was mainly transgressive, and its deposits form the lower part of the three-fold Zuni sequence (Sloss, 1963; Shurr and others, 1989).

During the early Middle through early Late Jurassic, the eastern side of the middle Western Interior seaway contained a broad, shallow-marine shelf referred to as the Wyoming shelf. There were, however, areas of positive and negative relief on this side of the seaway. The major positive features were the emergent, generally east-trending Belt Island Uplift in central Montana and the mostly(?) submergent northeast-trending Sheridan Arch (Peterson, 1957a) in northern Wyoming (fig. 4). These positive features influenced marine circulation and deposition in the seaway. Based on evidence obtained from isopach maps of various Jurassic units, Peterson (1957b) stated that less significant positive features, presumably submergent, existed during the Jurassic near the positions of the Black Hills and Bighorn Uplifts (Mirsky, 1962a) and other positive Laramide structures in central Wyoming. The major negative feature on the eastern side of the middle Western Interior seaway was the Williston Basin in eastern Montana, western North Dakota, and southern Saskatchewan, Canada, which received as much as $1,300 \mathrm{ft}$ of sediments during the Jurassic (J.A. Peterson, U.S. Geological Survey, written commun., 1990). During this time, the area of the Powder River Basin was part of a relatively minor depression on the Wyoming shelf that formed a U-shaped embayment on the

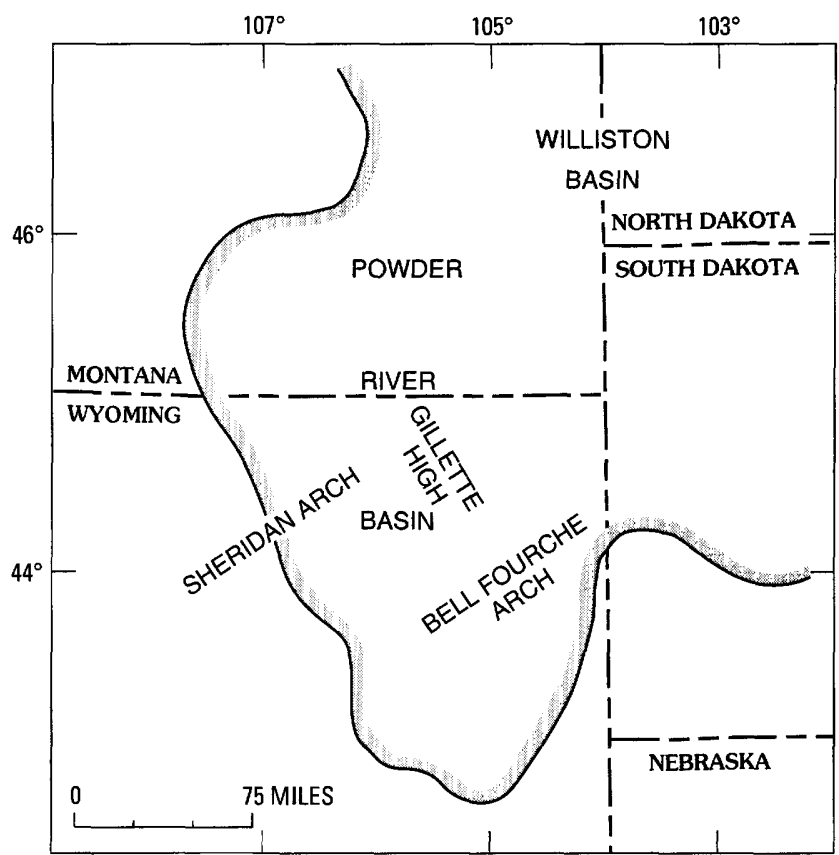

Figure 4. Jurassic tectonic elements in vicinity of Powder River Basin.

southern edge of the Williston Basin. The embayment, referred to in this report as the Powder River embayment, was perhaps partly separated from the Williston Basin by submerged positive features that include the Sheridan Arch, a small positive feature known as the Gillette High (Peterson, 1958), and possibly an incipient Black Hills Uplift (Peterson, 1958). Together, these features formed an effective shallow-marine barrier to water circulating south out of the Williston Basin. This barrier was particularly influential on deposition in the area of the Powder River Basin during the first and second major marine invasions of the area. During the forth major marine invasion, the sea was much deeper in this area, and the barrier effect was less. Isopach data presented by Peterson (1957b) support the existence, during the Jurassic, of an incipient Powder River Basin, as well as subtle Wind River and Bighorn Basins (Mirsky, 1962a).

The first marine invasion of the middle Western Interior occurred in the early Middle Jurassic when marine water from the north and west advanced south as far as northwestern Arizona and east across Wyoming into North Dakota (Imlay, 1980), almost to Minnesota (Imlay, 1952a). Very shallow water depths and hypersaline conditions existed on the eastern side of the middle Western Interior during the early history of the sea, but water depths increased and salinity decreased toward the end of the marine event. Later in the early Middle Jurassic, this sea, referred to in this report as the Gypsum Spring sea, withdrew from the middle Western Interior, and a regional unconformity (J-2) developed. The second marine invasion began during the latest early Middle Jurassic when marine 
water from the west again invaded the middle Western Interior. This marine body is referred to in this report as the early Sundance sea. Retreat of this sea from the eastern side of the middle Western Interior during late Middle Jurassic time resulted in a local, somewhat discontinuous unconformity (J-3). A subsequent rapid transgression representing the third marine invasion occurred later in the late Middle Jurassic creating the Pine Butte sea. The regression of this sea occurred at the close of the Middle Jurassic, and a regional unconformity ( $\mathrm{J}-4)$ developed throughout much of the area. The fourth marine invasion of the middle Western Interior began at the close of the Middle Jurassic when marine water from the west spread over a wide area. This sea is referred to in this report as the late Sundance sea. Later in the early Late Jurassic, the sea regressed from the eastern side of the middle Western Interior. This regression is now marked by a local and somewhat discontinuous unconformity (J-5). A final subsequent rapid transgression followed that represents the fifth and final marine invasion creating the Windy Hill sea. This sea began its retreat during the middle part of the early Late Jurassic, and, by the close of the early Late Jurassic, marine water had completely withdrawn from the middle Western Interior, ending the history of the Jurassic Western Interior seaway.

\section{STRATIGRAPHIC FRAMEWORK}

The lithostratigraphic nomenclature for the Jurassic System in the area of the Powder River Basin is outlined in figures 5 and 6. Darton (1899) originally described the Sundance Formation in the Black Hills and defined it as containing all of the marine strata between the red beds of the Upper Permian and Triassic Spearfish Formation and continental rocks of the Upper Jurassic. Darton did not assign a type section, but Imlay (1947) specified a reference section 1 mile north of Spearfish, South Dakota. The Sundance Formation is present throughout the Black Hills and eastern Wyoming. Equivalent strata in Montana are represented in the upper two formations (in ascending order Rierdon and Swift Formations) of the Ellis Group (Cobban, 1945). In westernmost Wyoming, rocks the same age as the Sundance are represented by the upper part of the Twin Creek Limestone, the Preuss Sandstone, and the Stump Formation. Imlay (1947) defined five members (Canyon Springs Sandstone, Stockade Beaver Shale, Hulett Sandstone, Lak, and Redwater Shale Members) for the Sundance in the Black Hills. Darton $(1899,1909)$ and Darton and Paige (1925) had previously recognized these natural subdivisions but did not define them as formal members. The members were later identified in the northern Laramie Range by Schmitt (1953), and Pipiringos (1968) later described them in this area and added two additional members (Pine Butte and Windy Hill Sandstone Members). Pipiringos and O'Sullivan (1976) traced several members south into northern Colorado, almost to Denver. West of the

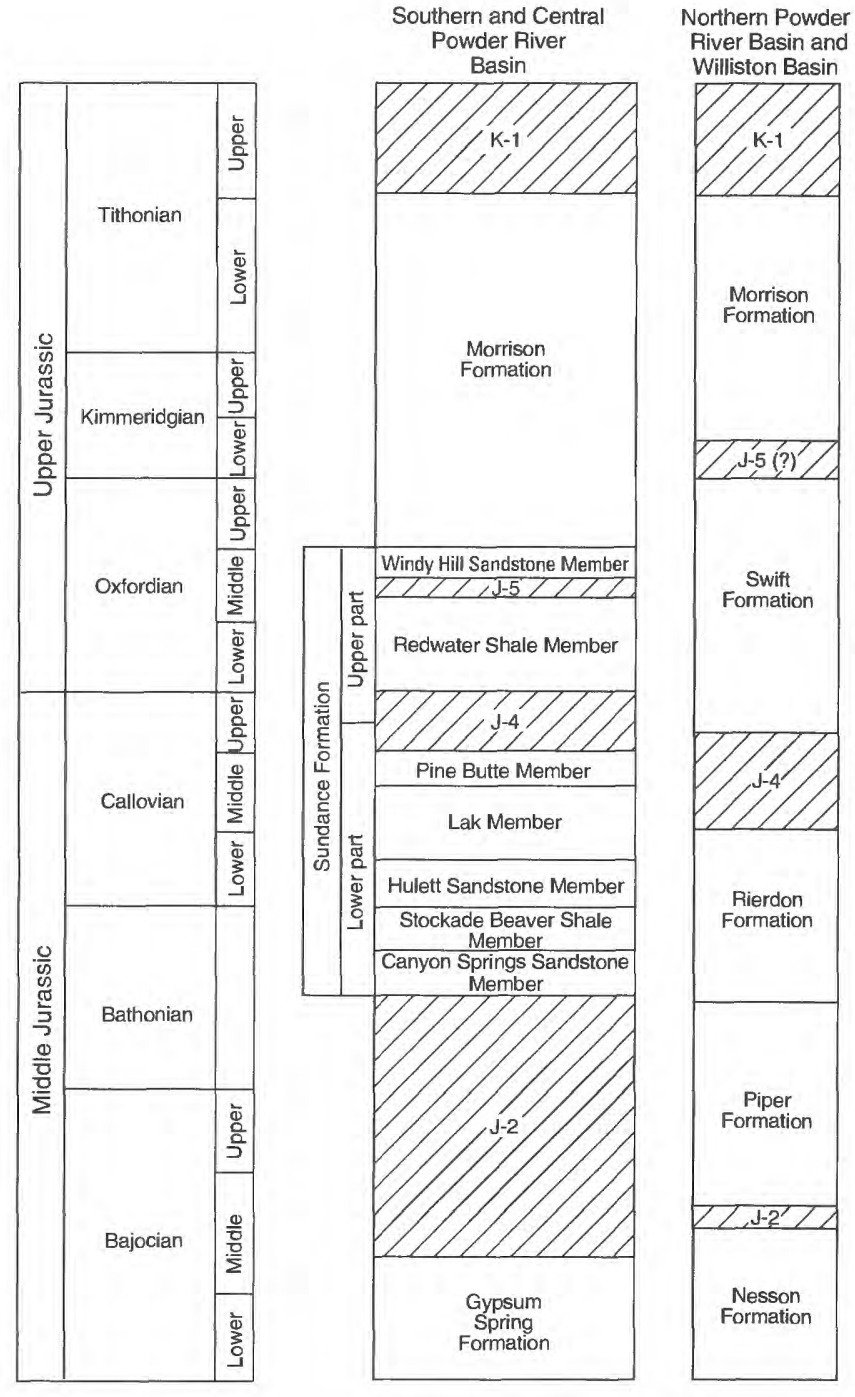

Figure 5. Generalized stratigraphy of Jurassic rocks in vicinity of Powder River Basin. J-2, J-4, and J-5 represent unconformities discussed in text. J-3 (not shown) is a local, somewhat discontinuous unconformity, and $\mathrm{K}-1$ is the unconformity betweeı Jurassic and Cretaceous rocks.

Black Hills, the members are difficult to identify in the subsurface of the Powder River Basin, and, where the Sundance reappears at the surface along the eastern flank of the Bighorn Mountains, some of the members are missing or unrecognizable. Because of this, many geologists working in the subsurface or with surface exposures beyond the Black Hills and the Laramie Range follow the informal terminology of Neeley (1937) and subdivide the Sundance into the "lower Sundance" and "upper Sundance." Peterson (1954a) proposed raising the Sundance Formation in Wyoming to group status, using the upper two formations (Rierdon and Swift) of the Ellis Group to represent the lower and upper Sundance, respectively, and retaining as members the subdivisions of Imlay (1947). This change in the Wyoming terminology was never accepted; however, Imlay (1980) stated that the east-trending line separating 


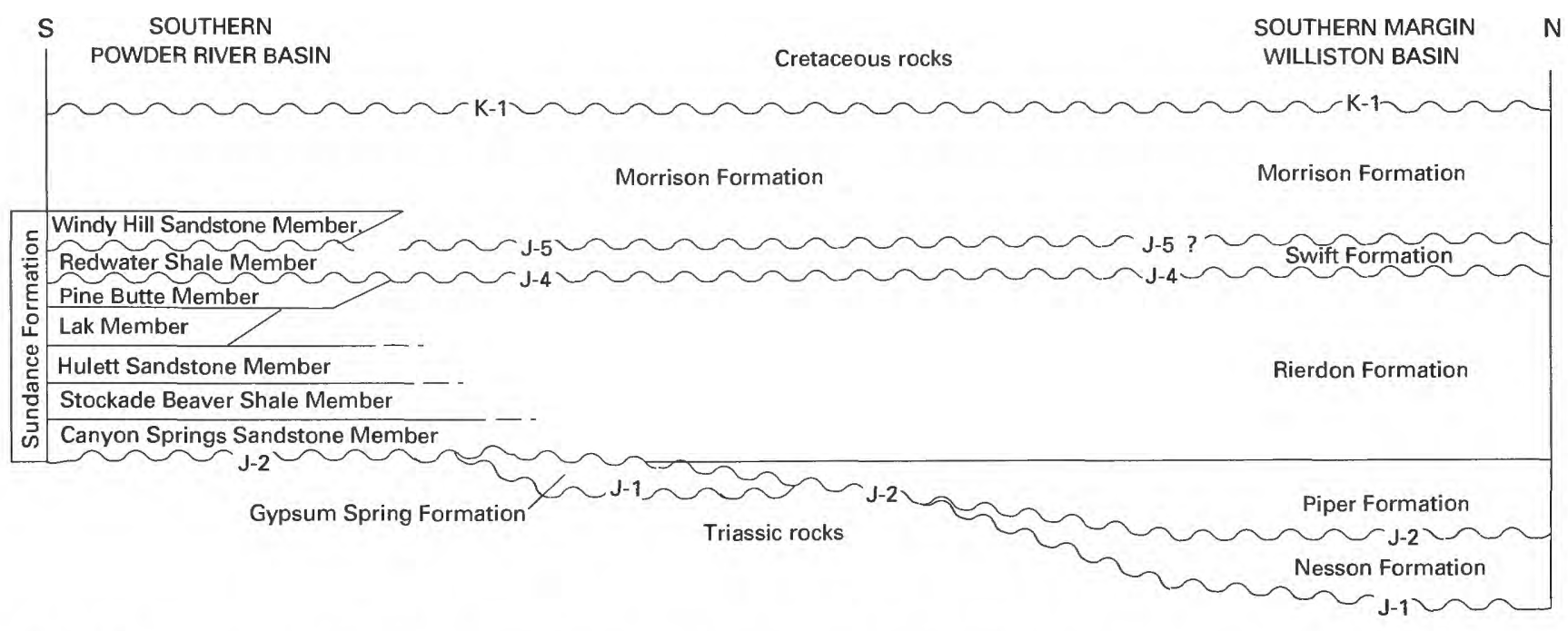

Figure 6. Generalized north-south cross section of Jurassic rocks in vicinity of Powder River Basin. No scale implied.

Sundance-like rocks from Ellis-like rocks is 30 miles south of the Montana-Wyoming State line in the vicinity of Banner, Wyoming. For detailed discussions of the early history of Sundance nomenclature, consult Neeley (1937) and Pipiringos (1957).

The next Jurassic unit to be identified in the area of the Powder River Basin was the Morrison Formation. Upper Jurassic continental rocks in this area were originally referred to as the "Atlantosaurus beds" or the Beulah Clay (Jenney, 1899). At the turn of the century, Darton (1901a), recognizing the similarities between these rocks and rocks described by Eldridge (1896) along the Colorado Front Range, introduced the term Morrison Formation to the Black Hills. The Morrison is one of the most widespread units in the Western Interior and extends from central New Mexico to southern Canada. Darton (1899) gave the name Unkpapa Sandstone to a unit of rock in the Black Hills that locally lies between the Sundance and the Morrison. Since that time, a number of workers have demonstrated that the Unkpapa is, in fact, a facies of the Morrison. Following the suggestion of Szigeti and Fox (1981), I consider the Unkpapa a member of the Morrison.

The last major Jurassic unit to be named in the area of the Powder River Basin was the Gypsum Spring Formation. This unit was originally defined as a member of the Triassic Chugwater Formation in central Wyoming (Love, 1939), but when it was found to contain a Middle Jurassic fauna it was raised to formation status (Love and others, 1945). Darton (1904) had described similar rocks in the Black Hills but included them in the top of the Spearfish Formation. Imlay (1947) later identified these rocks as Gypsum Spring and extended the name into the Black Hills.

The Jurassic stratigraphic framework contains a number of important unconformities (figs. 5, 6), many of which are of regional significance. Each of these erosional events represents either a major or a minor marine regression; the major events can be recognized on the proposed Jurassic sea-level curve of Hallam (1988). The nomenclature used to identify these surfaces $(\mathrm{J}-1, \mathrm{~J}-2, \mathrm{~J}-3$, $\mathrm{J}-4, \mathrm{~J}-5$, and $\mathrm{K}-1$ ) is that proposed by Pipiringos and O’Sullivan (1978).

\section{DEPOSITIONAL PACKAGES AND EROSIONAL EVENTS}

\section{Base of the Jurassic}

No Lower Jurassic rocks are in the area of the Powder River Basin; the closest such rocks, those of the Nugget Sandstone, are southwest of the basin in central Wyoming (Pipiringos and O'Sullivan, 1978). Although Lower Jurassic sediments may have been deposited and later removed by erosion, it is more likely that this area was a region of nondeposition and possibly a source of detritus for adjacent areas (F. Peterson, oral commun., 1990).

The oldest Jurassic rocks in the Powder River Basin are the earliest Middle Jurassic Gypsum Spring Formation, which lies on the Triassic Chugwater Group or, in the Black Hills, on the Upper Permian and Triassic Spearfish Formation. Where the Gypsum Spring is present, the contact separating the Jurassic and Triassic Systems is the J-1 unconformity, which represents about two to three million years of erosion (Pipiringos and O'Sullivan, 1978). Some tectonism must have preceded this erosional event because progressing northward along the eastern flank of the Bighorn Mountains the Gypsum Spring overlies progressively older strata in the Chugwater. Because the J-1 unconformity underlies the Gypsum Spring, the unconformity only occurs where this formation is present. 
In areas of the Powder River Basin where the Gypsum Spring was not deposited or was removed by the subsequent J-2 erosional event, the oldest Jurassic rocks are in the lower part of the Middle and Upper Jurassic Sundance Formation. In these areas the Jurassic and Triassic Systems are separated by the regionally extensive J-2 unconformity. The areal extent of the $\mathbf{J}-1$ unconformity is thus limited by that of the J-2 unconformity.

\section{The Gypsum Spring Sea}

The Gypsum Spring sea represents the first of five marine invasions that occurred in the area of the Powder River Basin during the early Middle through early Late Jurassic. In the early Bajocian (Imlay, 1980), marine water advanced east across part of the middle Western Interior. The Williston Basin was inundated, and in Wyoming all but the southeastern and northwestern parts of the State were flooded (fig. 7). Thus, marine water did not reach the southern part of the Powder River Basin. During this marine episode, the Nesson Formation was deposited in the Williston Basin and the Gypsum Spring Formation in the northern and central parts of the Powder River Basin. This relatively short-lived sea withdrew from the area by the early middle or middle middle Bajocian (Imlay, 1980).

\section{Shallow-Marine Evaporite, Carbonate, and Muddy Rocks}

Rocks in Wyoming and western South Dakota deposited in the Bajocian sea are included in the Gypsum Spring Formation. Love (1939) described the Gypsum Spring as a 250 -ft-thick sequence of gypsum, red shale, and carbonate rocks exposed near a gypsum spring in the northwestern part of the Wind River Basin. He designated these rocks as a member of the Triassic Chugwater Formation. After Middle Jurassic fossils were identified from the unit, Love and others (1945) modified the original description and raised the Gypsum Spring to formation status. Darton $(1899,1901 b)$ recognized a similar sequence in the Black Hills that he included in the Upper Permian and Triassic Spearfish Formation. Imlay (1947) compared these rocks with the Gypsum Spring of central Wyoming and extended the name into the Black Hills despite the lack of physical correlation.

The lithology of the Gypsum Spring marginal to the Powder River Basin varies considerably, and intertonguing of adjacent lithofacies is common. Where exposed along the eastern flank of the Bighorn Mountains south of the Wyoming-Montana State line, the formation can be divided into a lower gypsiferous facies and an upper carbonatebearing facies. The gypsiferous facies includes dark-red to reddish-brown, calcareous siltstone, shale, and claystone.

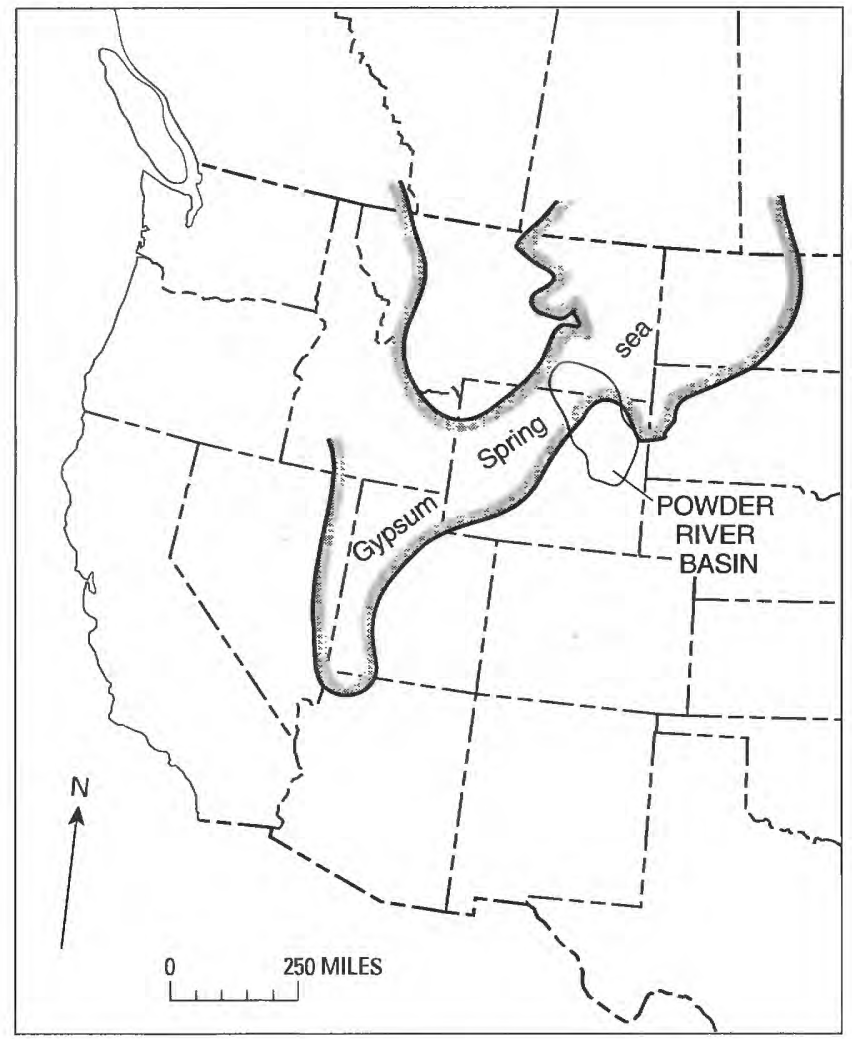

Figure 7. Approximate maximum areal extent of Bajocian Gypsum Spring sea in Western Interior. Modified from Imlay (1980).

White gypsum commonly is present as isolated pods and beds within the sequence (in the subsurface the mineral is anhydrite). More typically, the gypsum has been leached out, leaving in its place a vuggy argillaceous rock or limestone breccia. The overlying carbonate-bearing facies is similar except that it lacks gypsum and contains a varying number of light- to dark-gray, argillaceous, fossiliferous, thin-bedded limestone beds that form ledges $1-4 \mathrm{ft}$ thick (fig. 8). Mapel (1959) reported that locally in the Little Goose Creek area in Sheridan County, the upper carbonatebearing facies is overlain by $60 \mathrm{ft}$ of dark-red to pale-green, calcareous shale or claystone. A similar unit, but commonly including minor amounts of gypsum, is reported to exist at the top of the Gypsum Spring in nearby areas of central Wyoming. Imlay (1980) reported that this unit in the Bighorn Mountains might be a southward extension of the upper part of the Piper Formation of the Williston Basin and not part of the Gypsum Spring. South of Little Goose Creek in the Crazy Woman Creek area of Johnson County, the Gypsum Spring is reported to contain a middle unit consisting of $20-40 \mathrm{ft}$ of reddish-brown calcareous claystone that separates the lower gypsiferous and upper carbonate-bearing facies (Hose, 1955). 


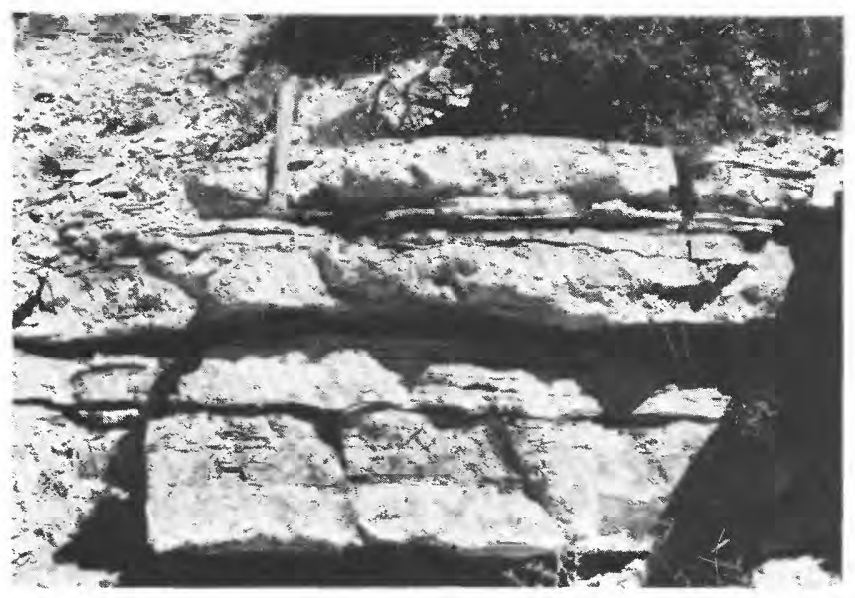

Figure 8. Limestone unit in Gypsum Spring Formation southwest of Buffalo, Wyoming, east flank of Bighorn Mountains. Hammer shown for scale.

The Gypsum Spring crops out along the western and northern flanks of the Black Hills and contains three major facies. The lower facies consists of varying amounts of white, massive gypsum and thin, red siltstone, shale, and claystone interbeds. The middle facies consists of red, green, or gray, calcareous claystone and some isolated gypsum lenses. This facies may correspond to the claystone unit described by Hose (1955) in the middle of the Gypsum Spring on the eastern flank of the Bighorn Mountains. The upper facies is similar to the middle facies except that it lacks gypsum and contains light-gray limestone beds $1-4 \mathrm{ft}$ thick. The limestone is locally gypsiferous, and beds near the base of the sequence contain pods and lenses of chert (Robinson and others, 1964). If a claystone unit was deposited above the upper facies corresponding to the unit described by Mapel (1959) at the top of the Gypsum Spring on the east flank of the Bighorn Mountains, it was removed by pre-Sundance erosion. Because of pre-Sundance tectonism and erosion, the most complete exposures of Gypsum Spring are in the northern part of the Black Hills, and the formation thins toward the south at the expense of younger parts of the unit until only the lower facies is left (Robinson and others, 1964). Hose (1955) reported a similar southward thinning of the Gypsum Spring in the Bighorn Mountains. Clastic rocks in the Gypsum Spring are generally nonresistant and form slopes that separate ledges of the more resistant gypsum and limestone. Detailed descriptions of Gypsum Spring rocks in central and eastern Wyoming are presented by Mapel and Bergendahl (1956), Peterson (1957b), and Wright (1973).

The Gypsum Spring lies unconformably (J-1) above the Chugwater Group on the eastern and southern margins of the Powder River Basin and above the Spearfish Formation in the Black Hills. In all areas marginal to the Powder River Basin, the Gypsum Spring lies unconformably (J-2) below the Sundance Formation; an exception to this might be in the northern Bighorn Mountains if the red claystone unit generally included at the top of the Gypsum Spring is actually the upper part of the Piper Formation, as postulated by Imlay (1980).

Reported thicknesses of the Gypsum Spring are 95-180 ft on the eastern flank of the Bighorn Mountains and 4.5-125 $\mathrm{ft}$ in the Black Hills. In general, the formation thins to the south on the eastern and western sides of the Powder River Basin. Variations in thickness are attributed to (1) local differences in original thickness, (2) regional depositional thinning to the southeast, (3) solution of gypsum, and (4) beveling of the top of the unit during the J-2 erosion interval. The thickness lost by solution of gypsum can reduce the original value by as much as one-third. The most accurate thickness values are obtained from subsurface measurements in areas where solution has not occurred. The formation does not exist south of an east-trending line connecting Mayoworth, Wyoming, in the Bighorn Mountains (Hose, 1955) and Clifton, Wyoming, in the Black Hills (Cuppels, 1963). The zero edge is the result of pre-Sundance erosion; the depositional zero edge presumably was somewhere southeast of this line.

The Gypsum Spring is present in the subsurface east of the Black Hills, but its extent in this direction is poorly known. The formation does not extend into the southern part of the Powder River Basin. To the west, the formation thickens with the addition of limestone, and the formation is included in the lower part of the Twin Creek Limestone in western Wyoming (Love, 1939). For many years the Gypsum Spring was thought to be at least partly equivalent to the Piper Formation of Montana (see Imlay, 1947, and Peterson, 1957b). The two formations are lithologically similar and both contain a Middle Jurassic fauna, but the physical correlation of these two units has never been demonstrated. In 1978, Pipiringos and O'Sullivan reported that the two formations lie on different sides of the $\mathrm{J}-2$ unconformity, proving that the Gypsum Spring is older than the Piper and that the two are separated by a major surface of erosion. The Gypsum Spring is probably the rockstratigraphic equivalent of at least part of the Nesson Formation (Nordquist, 1955) of the Williston Basin. The Nesson exists only in the subsurface and is known to lie above the $\mathrm{J}-1$ unconformity and below the $\mathrm{J}-2$ unconformity (Pipiringos and O'Sullivan, 1978; Imlay, 1980). The most likely direct equivalent (though possibly older) is the Poe Evaporite Member in the lower part of the Nesson (fig. 9). The southern extension of the Piper into the northern part of the Powder River Basin and the northern extension of the Gypsum Spring into the Williston Basin are poorly documented. It is interesting to note that J.D. Love (as reported in Robinson and others, 1964) has stated that the sequence of strata in the Black Hills correlated with the Gypsum Spring of central Wyoming might, in fact, not be Gypsum Spring at all but instead a southern extension of part of the Piper. 


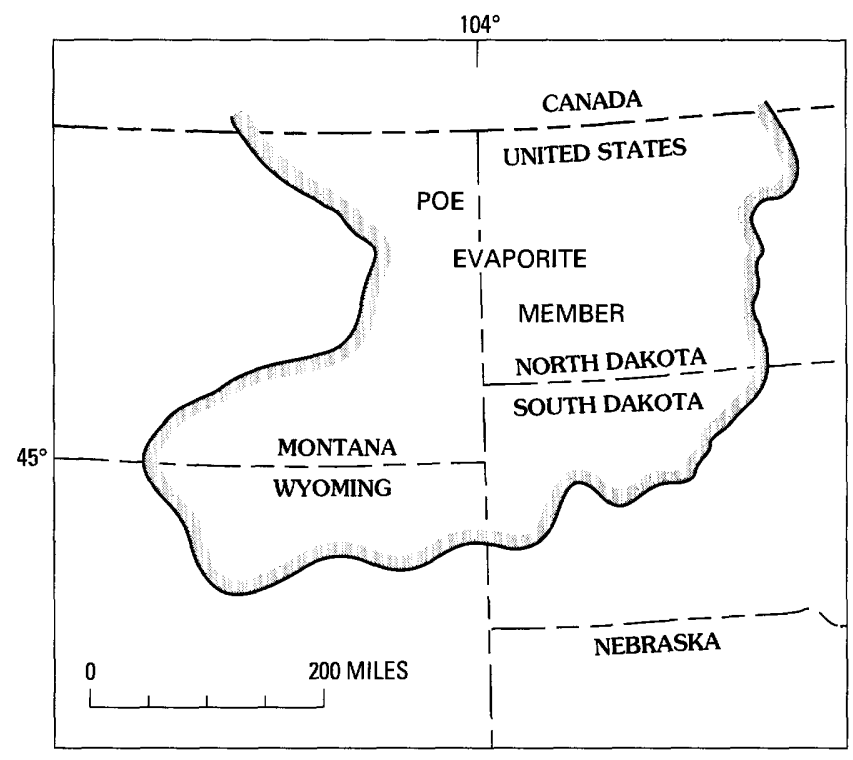

Figure 9. Approximate maximum areal extent of Poe Evaporite Member of the Nesson Formation in vicinity of Powder River Basin. Modified from Anna (1986).

Only ostracodes and poorly preserved casts and molds of unidentifiable pelecypods are reported from the Gypsum Spring marginal to the Powder River Basin. Imlay (1980) assigned an early to middle Bajocian age to the Gypsum Spring based on stratigraphic relations and a better preserved and more diagnostic fauna from adjoining regions. Wright (1973) presented a complete description of the fauna from this formation.

The Gypsum Spring in eastern Wyoming was deposited in a semirestricted marine environment on a shallow shelf that extended westward into central Wyoming and northward toward the Williston Basin. Irregularities on the pre-Gypsum Spring surface formed semi-isolated basins in the shelf area following the initial early Bajocian marine transgression (Peterson, 1957b; Greene, 1970). Gypsum in the lower part of the formation was deposited under arid conditions in restricted, hypersaline lagoons on the margins of some of these basins. This interpretation is supported by variations in gypsum thickness. The red argillaceous rocks in the lower part of the formation accumulated on the shelf near the semi-isolated basins in association with the gypsum. The source area for most of these clastic deposits, as for all clastic sediments in the formation, was the topographically low land areas to the east and south of the Bajocian sea. The overlying carbonate-bearing part of the Gypsum Spring was deposited following infilling of the semirestricted basins. An environment favoring deposition of carbonate was created by the periodic flushing of the shallow shelf by marine water of normal salinity, perhaps during minor rises in sea level such as during storm activity (Green, 1970; Wright, 1973), or by slight eustatic changes. Variations in thickness (or absence) of the carbonatebearing part of the formation represent limited or no flushing activity (Wright, 1973). Peterson (1957b) and Kocurek and Dott (1983) stated that maximum marine transgression during the Bajocian is probably represented by these carbonate deposits. The red argillaceous rocks containing minor amounts of gypsum that are reported in the uppermost part of the Gypsum Spring represent a return to semirestricted marine conditions but without the isolated basins of earlier times. These deposits may correspond to a general regression of the Bajocian sea. In the area of the Powder River Basin, the semirestricted marine conditions and the southern depositional limit of the formation might have resulted in part from the barrier effect of the northeasttrending submergent(?) Sheridan Arch (Peterson, 1958).

\section{Early Middle Jurassic Erosion}

After the Gypsum Spring sea retreated westward in the early middle Bajocian, a period of erosion began throughout the Western Interior that is now represented by the $\mathrm{J}-2$ unconformity. This unconformity is recognized throughout the Rocky Mountain region from the Black Hills in western South Dakota to as far south as northeastern Arizona where it separates the Lower Jurassic Navajo Sandstone from the overlying Middle Jurassic Carmel or Page Formations. The marine regression that produced the $\mathrm{J}-2$ can possibly be identified on the proposed Jurassic sealevel curve of Hallam (1988).

In the central and southern parts of the Powder River Basin, the $\mathrm{J}-2$ unconformity separates the Sundance from the underlying Gypsum Spring or, where the Gypsum Spring is missing, from the underlying Chugwater Group or the Spearfish Formation. In the northern Bighorn Mountains in south-central Montana, the unconformity separates the Piper Formation from the underlying Chugwater Group. In the subsurface of the Williston Basin, the unconformity separates the Piper Formation from the underlying Nesson Formation. The J-2 unconformity is recognized throughout the southern and middle Western Interior by the presence of scattered chert pebbles at, or locally as much as $6 \mathrm{ft}$ above, the erosion surface (Pipiringos and O'Sullivan, 1978). In the area of the Powder River Basin, these pebbles have been reported as far north in the Bighorn Mountains as the Sheridan, Wyoming, area (Mapel, 1959), and throughout the Black Hills (Imlay, 1947; Robinson and others, 1964), although locally the pebbles are missing (Mapel and Pillmore, 1963a). In the central and southern parts of the Powder River Basin, the pebbles are at the base of the Canyon Springs Sandstone Member of the Sundance or, where the Canyon Springs is missing, at the base of the Stockade Beaver Shale Member of the Sundance. The pebbles are generally banded, light to dark gray, angular to subrounded, and 1-2 inches in diameter, although larger diameters are common. Robinson and others (1964) described some clasts having diameters as large as $1.5 \mathrm{ft}$. Pipiringos and O'Sullivan (1978) reported that in north- 
eastern Wyoming most of the pebbles were locally derived from erosion of the underlying Gypsum Spring and accumulated on the erosion surface as a lag deposit. Most of the pebbles are fluted or etched, most appear polished as if by the wind, and some are coated with what might be desert varnish. These characteristics have led many observers to interpret these pebbles as ventifacts; however, in the Douglas, Wyoming, area, Pipiringos and O'Sullivan (1978) reported that some of the pebbles might be water rounded.

Erosional relief on the surface of the J-2 unconformity is generally minor throughout the southern and middle Western Interior; however, in central and eastern Wyoming, local relief is generally about $50 \mathrm{ft}$. In the southern part of the Power River Basin, even greater relief has created "buried hills," a subsurface term used by petroleum geologists in reference to the Triassic surface upon which the Canyon Springs was deposited. Dresser (1959), in the Douglas, Wyoming, area, described outliers of the Canyon Springs surrounded by rocks of the Chugwater Group that he interpreted as paleovalley-fill deposits. At one location, an outlier of Canyon Springs rests on the Lower Permian and Triassic Goose Egg Formation; this juxtaposition requires $700 \mathrm{ft}$ of erosional relief. In eastern Wyoming, the $J-2$ is an angular unconformity resulting from mild regional upwarping after deposition of the Gypsum Spring and before deposition of the Sundance. As a result of this upwarping, pre-Sundance strata are inclined slightly toward the southwest (Dresser, 1959). On the eastern flank of the Bighorn Mountains and in the Black Hills, the Gypsum Spring is known to thin southward as upper parts of the formation are beveled by $\mathrm{J}-2$ erosion. Love and others (1945) recognized a similar phenomena from west to east in the Wind River Basin. Love and others (1949), in the Glendo, Wyoming, area, reported that the J-2 unconformity overlies successively younger strata of the Chugwater Group toward the west. Imlay (1980) reported the J-2 to be a disconformity in the subsurface of the Williston Basin. According to Pipiringos and O'Sullivan (1978) the age of the J-2 erosional event is middle Bajocian.

\section{Post-Erosional Phase}

Pipiringos and O'Sullivan (1978) stated that about one million years elapsed before sediments were deposited anywhere on the J-2 erosional surface and that about five million years were required to completely cover the unconformity throughout the Western Interior. Thus, the surface was exposed for about one to six million years. During this time, differential erosion created topographic relief on the surface and, most likely, superficial deposits accumulated.

\section{Eolian Sandy Rocks}

The first unit deposited on the J-2 erosional surface in the central and southern parts of the Powder River Basin was the Canyon Springs Sandstone Member of the Sundance Formation that is described later in this report. The sandstone is generally considered to be a shallow-marine deposit, but, based on observations of outcrops in the southern part of the basin and throughout much of southeastern Wyoming, many geologists have long considered at least some of the lower part of the Canyon Springs to be eolian in origin. This interpretation is supported by the occurrence of large-scale cross-stratification of probable eolian type. Moreover, chert pebbles in the base of the Canyon Springs are thought to represent ventifacts, and the sandstone contains abundant frosted quartz grains. Frosted grains are common in all sandstones in the lower part of the Sundance in this area of Wyoming, however, and their presence in the Canyon Springs might just as well be indicative of the depositional environment of the source rock. Despite the general acceptance of an eolian origin for at least part of the Canyon Springs, documentation in the literature for this interpretation is lacking. It is not unreasonable to expect eolian sediments to have accumulated on the $\mathrm{J}-2$ surface considering the long exposure time. Moreover, the climate during this part of the Jurassic was hot and arid (Kocurek and Dott, 1983). Over much of southern Wyoming, the Nugget Sandstone, Jelm Formation, or Crow Mountain Formation directly underlies the $\mathrm{J}-2$ surface, and erosion of these units would have supplied ample amounts of sand for dune construction. Marine processes would have extensively reworked any such terrestrial deposit during the subsequent transgression and thus partly modified primary eolian features.

\section{The Early Sundance Sea}

The early Sundance sea (fig. 10) began advancing in the late middle Bajocian (Imlay, 1980). In central Wyoming, the $\mathbf{J}-2$ surface was onlapped as marine water advanced from the west and north. Pipiringos and O'Sullivan (1978) calculated an onlap rate of 330-525 miles per million years for this marine incursion in the Western Interior based on the known ages of units below and above the $\mathrm{J}-2$ unconformity. In Montana, marine water first transgressed from the west and deposited the Piper Formation in the Williston Basin. According to Imlay (1980), marine deposition did not begin in northeastern Wyoming until the late Bathonian. At this time marine water advanced from the Williston Basin into the Powder River embayment and as far south as northern Colorado. During this part of the marine event, rocks between the $\mathrm{J}-2$ and $\mathrm{J}-4$ unconformities were deposited. In eastern Wyoming and western South Dakota the Canyon Springs Sandstone, Stockade Beaver Shale, Hulett Sandstone, and Lake Members of the Sundance Formation were deposited. Equivalent rocks deposited in the Williston Basin are in the Rierdon Formation. The sea withdrew in the early late Callovian (Imlay, 1980), perhaps accompanied by regional 


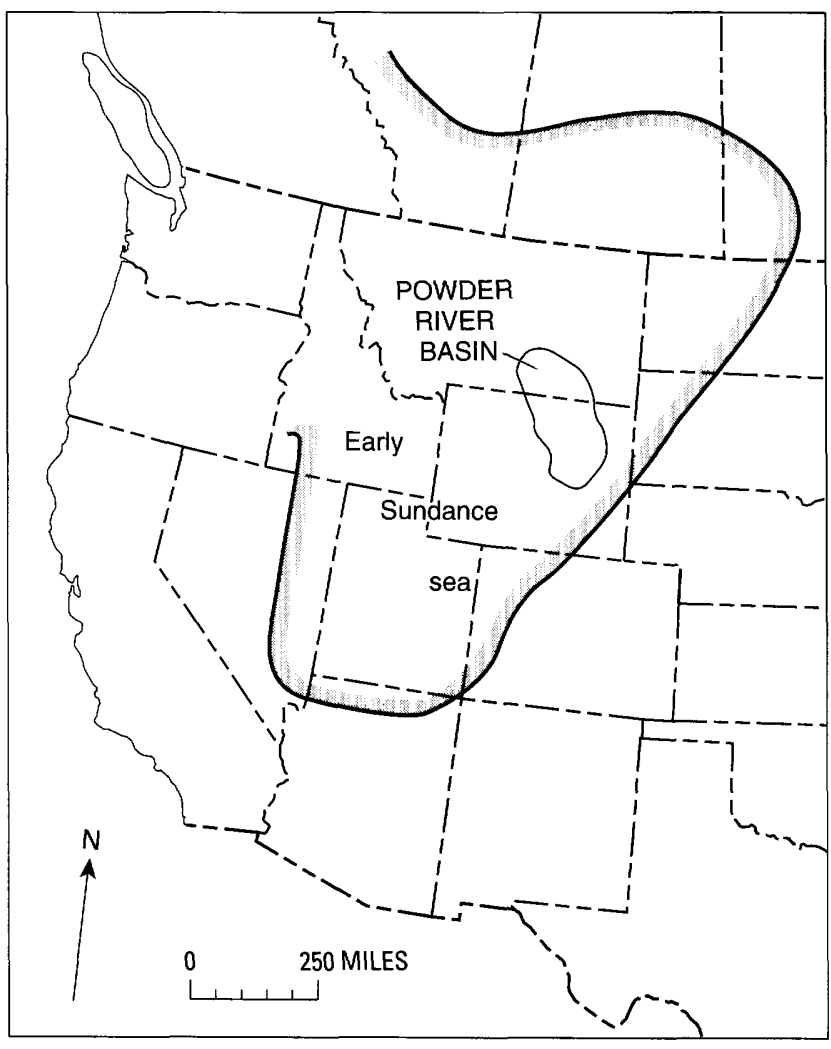

Figure 10. Approximate areal extent of Bathonian-Callovian early Sundance sea in Western Interior. Modified from Brenner (1983).

uplift to the west (Peterson, 1957a). The areal extent at maximum inundation during this event exceeded that of the earlier Gypsum Spring sea, and deposits of the lower part of the Sundance extend beyond the zero edge of the underlying Gypsum Spring Formation. Based on oxygen isotopes, Bowen (1961) determined that the temperature of this sea during the Callovian was a warm $75^{\circ} \mathrm{F}$.

An isopach map of strata deposited in the early Sundance and Pine Butte seas in the Wyoming part of the Powder River Basin constructed from subsurface data is shown in figure 11 (J.E. Fox, South Dakota School of Mines and Technology, unpub. data base, 1990). Thicknesses are 80-200 ft. A northeast-trending zone of thin deposits in the northern part of the map area probably represents the Sheridan Arch. A smaller symmetrical area of thin rocks in the vicinity of Gillette, Wyoming, probably represents the Gillette High. The largest area of thin deposits is a northeast-trending zone in the southern part of the basin here named the Pine Tree Arch.

\section{Shallow-Marine Evaporite, Carbonate, and Muddy Rocks}

As the early Sundance sea advanced eastward across the $\mathrm{J}-2$ erosional surface into the Williston Basin, the Piper Formation was deposited over the Nesson Formation.

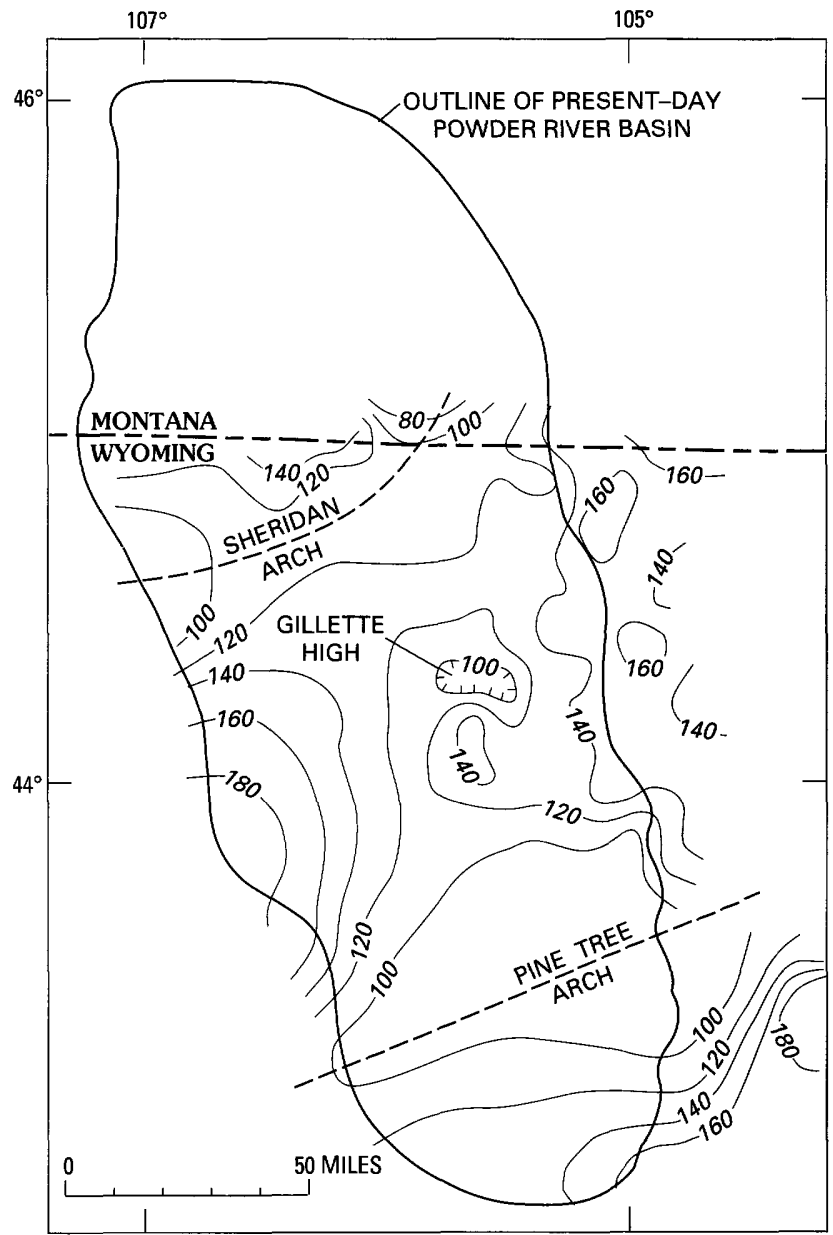

Figure 11. Isopach map of lower part of Sundance Formation (Canyon Springs Sandstone through Pine Butte Members) in Wyoming part of the Powder River Basin. Contour interval $20 \mathrm{ft}$. Dashed lines represents thinning trends. Modified from J.E. Fox (unpub. data base, 1990).

Evidently, at the same time that the Piper was being deposited on the $\mathbf{J}-2$ surface in the Williston Basin, eolian sand was accumulating on the $\mathbf{J}-2$ surface in southern Wyoming. Imlay and others (1948) proposed the name Piper Formation for a 100-ft-thick sequence that crops out near the town of Piper in central Montana and consists of red shale and gypsum and an intervening limy middle part. Three members were later designated by Nordquist (1955); in ascending order they are the Tampico Shale, Firemoon Limestone, and Bowes Members. These names correspond to the informal "Piper A," "Piper B," and "Piper C" of Peterson (1957a). Although limited to the Williston Basin, the maximum areal extent of the Piper exceeds that of the subsurface Nesson, and the Piper is exposed west of the basin. It is possible that the Sheridan Arch created a temporary barrier to the southern extension of the marine water into the Powder River embayment (Peterson, 1957a, 1958). The southern zero edge of the Piper has not been documented, but the formation name is generally restricted to Montana. 
The Piper is well exposed along the northeastern flank of the Bighorn Mountains north of the MontanaWyoming State line. Because the formation was deposited on the irregular J-2 surface, thicknesses vary considerably. In the northern Bighorn Mountains the unit is generally about $150 \mathrm{ft}$ thick, but Richards (1955) reported thicknesses of 90-200 ft. The Tampico ("Piper A") is about $60 \mathrm{ft}$ thick and consists of a massive white gypsum unit, locally interbedded with red shale, that generally makes up most of the lower half of the member. Overlying the gypsum is a sequence of reddish-brown shale that contains scattered pods of white gypsum. The Firemoon ("Piper B"), sometimes referred to in the subsurface as "Piper lime," is about $50 \mathrm{ft}$ thick and consists of several limestone units 1-12 ft thick separated by intervals of calcareous, red to brown shale. The limestone is gray and thin to thick bedded and contains green to brown shale partings. The Bowes ("Piper C"), sometimes referred to in the subsurface as "upper Piper red," consists of a sequence of calcareous, reddish-orange, sandy siltstone and local pods of gypsum and is about $40 \mathrm{ft}$ thick. Limestone units in the Piper generally form small hogbacks, and argillaceous units generally form slopes, especially the Bowes.

In the northern Bighorn Mountains the Piper Formation is generally described as resting unconformably ( $\mathrm{J}-2)$ on the Chugwater Group; however, Imlay (1980) reported that north of Banner, Wyoming, red claystone generally included at the top of the Gypsum Spring Formation was, in fact, the upper part of the Piper. If this is correct, then at least part of the Piper rests unconformably(?) on the Gypsum Spring. As mentioned before, these two formations are lithologically similar, and, should they be laterally or vertically adjacent, separating one from the other could be difficult. The Piper lies conformably below the Rierdon Formation.

Fossils are uncommon in the Piper in the northern Bighorn Mountains. Imlay (1980) assigned an age of late middle Bajocian to Bathonian to the formation.

Although the Piper and the Gypsum Spring are on opposite sides of the J-2 unconformity and therefore cannot be equivalent, the two formations contain similar lithofacies arrangements and therefore probably had a similar depositional history. The lower member of the Piper was evidently deposited in a shallow restricted-marine environment under conditions conducive to evaporite deposition. The middle carbonate-bearing member was deposited under more normal-marine conditions, and the upper member probably represents a return to at least a semirestricted marine environment. The lower member probably was deposited under transgressive conditions, and transgressive maximum is represented by the carbonate rocks in the middle member. Regression might have reduced water depth at the close of Piper time and is represented by the upper member, but marine water probably never completely receded from the Williston Basin.

\section{Transgressive Nearshore Sandy Rocks}

During the Bathonian, a major transgressive event occurred in the middle Western Interior when the early Sundance sea spread south and east across the J-2 erosion surface into central and eastern Wyoming. The transgression must have been relatively rapid because wave erosion failed to reduce the topographic relief on the $\mathrm{J}-2$ surface (Dresser, 1959). When marine water reached the area of dune accumulation in southern Wyoming, the eolian sediments were partly reworked by marine processes and the resulting deposit of marginal-marine and eolian beds is included in the Canyon Springs Sandstone Member of the Sundance Formation. The Canyon Springs was named and described by Imlay (1947) for an exposure 4 miles northwest of Horton, Wyoming, in the southern part of the Black Hills. Pipiringos (1968) described the member in the Laramie Range.

In simplest form, the Canyon Springs consists of two parts: a massive to large-scale cross-stratified sandstone lithofacies in the lower part and a flatbedded sandstone lithofacies in the upper part. The lower of the two facies is generally thicker. The thicknesses of the two facies vary considerably, and the facies can lack some or all of their characteristic features.

Sandstone in the lower massive to large-scale crossstratified sandstone facies is light yellowish gray, (locally weathering to light pink or red), quartzose, calcareous, subangular to subrounded, well sorted, and very fine to fine grained. Scattered well-rounded, medium to coarse, frosted grains are common. Dresser (1959) reported the crossstratification, where present, to be large-scale planar or small- to large-scale trough type. Soft-sediment deformation is common (Rautman, 1976a). Poorly preserved external molds of oysters and other bivalves are rare. Bioturbation, tracks and trails, and burrows (including Ophiomorpha and possibly Terebellina) are locally present. The sandstone is friable in hand sample, and large outcrops of this part of the Canyon Springs commonly weather into rounded cliffs. Dark-colored chert pebbles associated with the $\mathrm{J}-2$ unconformity are at and near the base of the sandstone as isolated clasts or concentrated in a discontinuous basal unit of calcareous, conglomeratic, very fine grained sandstone as thick as $1 \mathrm{ft}$. At some locations, a unit of light-gray, calcareous, parallel-bedded siltstone is at the base of the member. In the subsurface of the southern part of the Powder River Basin, the lower part of the Canyon Springs Sandstone has an argillaceous limestone cap (Curry and Hegna, 1970) that T.S. Ahlbrandt (U.S. Geological Survey, written commun., 1989) suggested is separated from the underlying sandstone by a minor unconformity. The thickness of the lower part of the Canyon Springs in the area of the Powder River Basin is variable because of the relief on the underlying Triassic surface and is $0-160 \mathrm{ft}$ but generally less than $50 \mathrm{ft}$. 


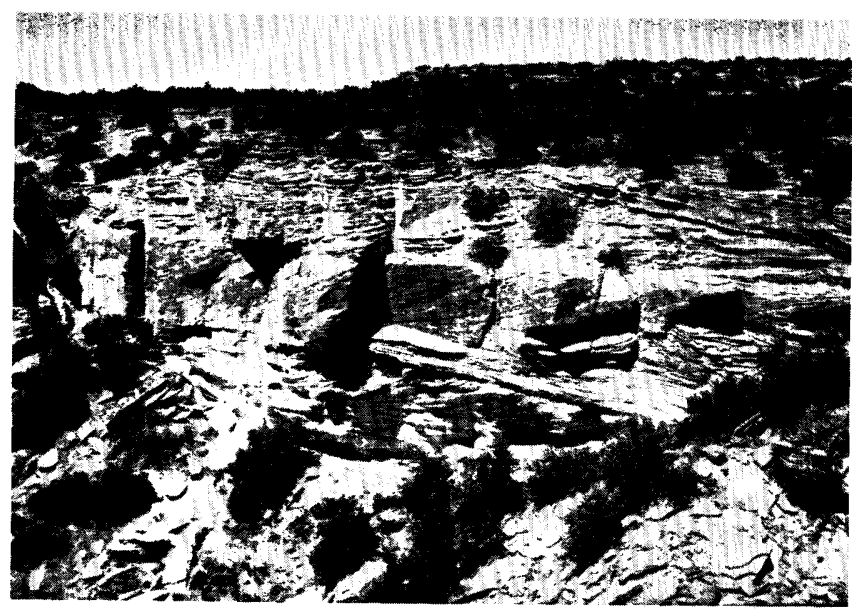

Figure 12. Flatbedded sandstone facies of Canyon Springs Sandstone Member of the Sundance Formation, southeastern Bighorn Mountains.

Sandstone in the flatbedded sandstone facies of the Canyon Springs is light to brownish gray, quartzose, calcareous, well sorted, very fine to fine grained, and locally fossiliferous. Although the range of grain size is the same for the two major sandstone facies in the Canyon Springs, Pipiringos (1968) reported that the flatbedded sandstone facies is generally coarser grained. The thin- to mediumscale beds are parallel with flat to wavy bedding planes. Planar laminations and ripple cross laminations are common, and small-scale cross-stratification is present locally. In some areas the total thickness of the upper part of the Canyon Springs consists of large-scale crossbedded cosets (fig. 12). This facies of the Canyon Springs is generally better cemented than the lower facies, and large outcrops commonly form steep cliffs. In some areas, ooids are scattered throughout this part of the Canyon Springs, commonly concentrated near the top in such numbers that the rock is a greenish-gray, thin- to medium-bedded, locally fossiliferous limestone unit as thick as $7 \mathrm{ft}$. Locally, algal structures are on the top surface of the limestone. In the area of the Powder River Basin, the upper part of the Canyon Springs is $0-80 \mathrm{ft}$ thick but generally less than $40 \mathrm{ft}$ thick. Pipiringos (1968) reported this facies to thicken southward in the Laramie Range and to be as thick as $165 \mathrm{ft}$ in north-central Colorado. Curry and Hegna (1970), in the southern part of the basin, considered this part of the Canyon Springs to be a facies of the overlying Stockade Beaver Shale Member of the Sundance.

The contact between the two major sandstone facies of the Canyon Springs is generally sharp, but erosion has occurred locally (Love and others, 1949; Post, 1967). T.S. Ahlbrandt (written commun., 1989) stated that in the subsurface of the southern part of the Powder River Basin a brown shale unit as thick as $40 \mathrm{ft}$ separates the two facies. This shale is at the same stratigraphic level as the "cephalopod sandstone" of Love and others (1949) in the Glendo, Wyoming, area and a shale locally present in the southeastern Bighorn Mountains. T.S. Ahlbrandt also stated that in the subsurface of the southern part of the Powder River Basin the upper facies of the Canyon Springs is overlain by a sequence of siltstone averaging $20 \mathrm{ft}$ thick that is referred to as the "siltstone marker." This siltstone is in the southern Black Hills and south of Douglas, Wyoming, in the northern Laramie Range. Rautman (1976a) recognized this unit and described it as a gray, friable, locally fossiliferous (oysters), poorly bedded to flatbedded siltstone that is 3-13 ft thick.

The Canyon Springs rests unconformably on the Gypsum Spring Formation in the central part of the Powder River Basin. In the southern part of the basin, where the Gypsum Spring was not deposited or has been removed by $\mathrm{J}-2$ erosion, the Canyon Springs rests unconformably on the Chugwater or the Spearfish. This contact is erosional and generally sharp. The Canyon Springs is overlain conformably by the Stockade Beaver Shale Member of the Sundance in all areas marginal to the Powder River Basin. This contact is generally very sharp, but lateral gradation into the lower part of the Stockade Beaver was reported by Wolcott (1967).

In eastern Wyoming, the Canyon Springs thins to the north and is not represented in the northern part of the Powder River Basin because of a facies change to argillaceous rocks. The east-trending depositional zero line extends from the Buffalo, Wyoming, area in the Bighorn Mountains to the Devils Tower area in the Black Hills. The member is well represented along southern margin of the Black Hills in the vicinity of Hot Springs, South Dakota, where the member is reported to be as thick as $89 \mathrm{ft}$ (Post, 1967). Northwest of this area along the western flank of the uplift, the member disappears through a distance of about 25 miles from Dewey, Wyoming, to Newcastle, Wyoming (Brobst, 1961; Brobst and Epstein, 1963; Cuppels, 1963). North of Newcastle, the member reappears (Mapel and Pillmore, 1963a), but it is thinner than to the south, lacks its distinctive character, and is poorly exposed. Rocks thought to be equivalent to the Canyon Springs can be traced as far north as the Devils Tower area, but north of this location the unit thins irregularly and is generally mapped as a sandy, lower part of the Stockade Beaver. The Canyon Springs is missing along the eastern flank of the Black Hills. The Canyon Springs has been correlated into the Hartville Uplift and the Laramie Range. In the vicinity of Glendo, Wyoming, in the Hartville Uplift, where the unit was originally termed the "basal sandstone of the Jurassic," the member is $21-110 \mathrm{ft}$ thick (Dresser, 1959). In the northern Laramie Range, south of Douglas, Wyoming, it is $46-102 \mathrm{ft}$ thick (Dresser, 1959; Pipiringos and O'Sullivan, 1976), and, in the Casper Mountain area, south of Casper, Wyoming, the member is 26-54 ft thick (Bergstrom, 1950; Dresser, 1959). On the eastern flank of the Bighorn Mountains, a sandstone unit having characteristics similar to the Canyon Springs is reported at the base of the Sundance as far north 
as 11 miles northwest of Buffalo, Wyoming, where Mapel (1959) measured a thickness of $37 \mathrm{ft}$. Geologists have generally accepted these rocks as being equivalent to the Canyon Springs of the Black Hills and the Laramie Range, but other than one mention of the member by Woodward (1957) in the Deadman Butte area at the southern end of the Bighorn Mountains, the member has not been formally recognized in the literature as present on the western side of the Powder River Basin. The variations in thickness of this member over relatively short distances throughout the Powder River Basin result from deposition on a surface having considerable erosional relief, the so-called "buried hills." In the subsurface of the southem part of the Powder River Basin, Curry and Hegna (1970) reported that the lower sandstone facies of the Canyon Springs was deposited only in the paleovalleys, but the stratigraphically higher parts of the member extend over the paleohills. T.S. Ahlbrandt (written commun., 1989) stated that only the siltstone unit at the top of the Canyon Springs extends across the highest paleohills.

The Canyon Springs is the most widespread member of the Sundance. The member can be identified in the subsurface east of the Black Hills (J.A. Peterson, written commun., 1990). To the south and southwest of the Powder River Basin, the member crosses time lines and becomes younger toward the Ancestral Rocky Mountains. The member extends southward into Colorado to the Boulder area where it grades into the lower part of the Ralston Creek Formation (Pipiringos and O'Sullivan, 1976). The younger part of the Canyon Springs that crops out in southern Wyoming southwest of the Laramie Range is equivalent to the Entrada Sandstone, and the older part of the Canyon Springs that crops out farther to the north in central Wyoming is equivalent to the upper part of the Carmel Formation of the Colorado Plateau region (Blakey and others, 1988; F. Peterson, 1988). In southeastern Idaho, rocks equivalent to the Canyon Springs are contained in the Watton Creek Member of the Twin Creek Limestone (Imlay, 1980). In the northern part of the Powder River Basin, the Canyon Springs is probably the stratigraphic equivalent of the limy, commonly oolitic unit that is common at the base of the Rierdon Formation in Montana (Imlay, 1956, 1980; Peterson, 1957a). As pointed out by Peterson (1958), the Canyon Springs, or its stratigraphic equivalent to the north, tends to be well developed in areas adjacent to Jurassic positive features such as the Ancestral Rocky Mountains in southern Wyoming or the Sheridan Arch in northern Wyoming.

The Canyon Springs, especially its lower part, was at one time thought to be the Nugget Sandstone or at least a stratigraphic equivalent of it. Pipiringos and O'Sullivan (1978) demonstrated, however, that the Canyon Springs and the Nugget lie on opposite sides of the J-2 unconformity. Moreover, Love and others (1949), in the Hartville Uplift, reported that the Canyon Springs thins to the west, whereas the Nugget in south-central Wyoming is known to thicken to the west. If the Nugget was a sediment source for the Canyon Springs, it is easy to understand why the two units were confused with each other.

In general, fossils are scarce in the Canyon Springs. Rautman (1976a) reported rare, poorly preserved external molds of oysters and other bivalves in the massive to large-scale cross-stratified sandstone facies and oyster shells in the siltstone unit at the top of the member. Rautman also reported on a fossil fish locality. A great variety of marine fossils are in the "cephalopod sandstone" in the middle of the member in the Hartville Uplift (Love and others, 1949). Imlay (1980) reported the Canyon Springs to be late Bathonian in age based on faunal data.

As mentioned in a previous section of this report, the lower part of the Canyon Springs has characteristics of eolian deposits. The upper part of the member, however, probably represents reworked eolian sediments deposited in a shallow-marine setting (Dressser, 1959; Rautman, 1976a). This interpretation is supported by the presence of marine trace and body fossils.

Northwest of the northern Laramie Range in the Rattlesnake Hills, the Canyon Springs is laterally equivalent to the generally lower part of the overlying Stockade Beaver (Pipiringos, 1968), and Wolcott (1967) recognized a similar relation in the southern Black Hills. This relation indicates that the Canyon Springs is, in reality, a shoreward facies of the Stockade Beaver (Wright, 1973).

The most complete set of paleocurrent data for the Canyon Springs is that published by F. Peterson (1988). These data indicate a southeast direction and agree with measurements I made in the southern Bighorn Mountains and in the northern Laramie Range.

Rautman (1976a) reported that sand in the Canyon Springs in south-central Wyoming is less well sorted and coarser grained than sand in the member in the Black Hills. This characteristic would seem to eliminate an eastern source for this member in south-central Wyoming because sediment bypass would be required for coarser detritus to reach the area. Paleocurrent data presented by F. Peterson (1988) for the Canyon Springs in southeastern Wyoming and north-central Colorado are variable but show a southeastern trend that supports a western source. To the north and west of south-central Wyoming the member is shaley. The Nugget Sandstone and Crow Mountain and Jelm Formations that underlie the Canyon Springs in southcentral Wyoming are possible sources for some of the clastic material in the member. Rautman (1976a) pointed out that the sharp sand-mud contact between the Canyon Springs and the Stockade Beaver might indicate that the sand was derived locally and that no additional sand was immediately available to enter the system following the 
marine transgression. In the Black Hills, the Canyon Springs overlies the Spearfish Formation, which consists mostly of siltstone; here the source for the member was probably to the east.

Oil was discovered in Jurassic rocks in the southernmost part of the Powder River Basin in 1930 (Love, 1958). Most of the oil is in the Canyon Springs, which was referred to as the basal sandstone of the Sundance at the time of discovery. The area of production is a 100mile-wide belt that trends northeast (Neely, 1937), and the majority of the oil accumulated in stratigraphic pinchouts against the so-called "buried hills" (Curry and Hegna, 1970). Lance Creek and Lightning Creek are the major producing fields in the area.

\section{Offshore Muddy Rocks}

Argillaceous sediments were deposited in offshore marine areas of the early Sundance sea. As marine water continued to transgress, argillaceous sediments onlapped deposits of the Canyon Springs, and the resulting deeper water deposit is included in the Stockade Beaver Shale Member of the Sundance Formation. The Stockade Beaver was named by Imlay (1947) for exposures on the western side of Stockade Beaver Creek, 5 miles northeast of Newcastle, Wyoming, in the southwestern Black Hills.

The Stockade Beaver is a sequence of muddy rocks that are silty and sandy in the upper part. The member can be divided into two lithofacies. The lower part of the Stockade Beaver contains the marine shale facies and consists of greenish-gray, calcareous, soft and waxy, fissile, clay shale that is organic rich and locally fossiliferous. Cuppels (1963) and Imlay (1980) reported some limestone beds and nodules near the base of this facies in the Black Hills. The marine-shale facies represents the maximum marine transgression of the early Sundance sea. Rautman (1976a) reported that along the western flank of the Black Hills this facies thins toward the south.

Regression of the sea is suggested by the coarseningupward facies in the upper part of the Stockade Beaver. This less fossiliferous facies consists of calcareous, silty to sandy shale and interbedded sandstone. The sandstone is light gray, calcareous, very fine to fine grained, and planar to ripple laminated. At the base of the facies the sandstone is present as sandy laminations in the shale or in very thin, lenticular to flaser beds. Toward the top of the facies the bed thickness increases to thin bedded and the number of beds increases. Bedding planes are commonly rippled, and straight-crested symmetrical ripples trending northeast are the most common. Rautman (1976a) reported interference and flat-topped ripples in the southern part of the Black Hills, and Specht and Brenner (1979) reported starved ripples. Bioturbation, burrows, tracks and trails, and wrinkle marks are also described in this facies. (Dresser, 1959; Rautman, 1976a). According to Rautman, this part of the member is best developed in the Black Hills, and along the western flank of the uplift the facies thickens toward the south. The Stockade Beaver is generally a nonresistant, poorly exposed slope former.

The lower contact of the Stockade Beaver with the Canyon Springs is conformable and can be sharp or gradational through a $1-\mathrm{ft}$ interval (Robinson and others, 1964); in areas where the Canyon Springs was not deposited, the Stockade Beaver rests unconformably (J-2) on older rocks. The upper contact of the Stockade Beaver with the Hulett Sandstone Member of the Sundance Formation is conformable and gradational through as much as $15 \mathrm{ft}$ of beds.

The Stockade Beaver has an inverse thickness relation with the Canyon Springs so that the Stockade Beaver is thick where the Canyon Springs is thin or missing (such as north of the Canyon Springs zero edge) and vice versa (Robinson and others, 1964; Pipiringos, 1968). In the Black Hills the Stockade Beaver is 6-90 ft thick (Imlay, 1947; Pillmore and Mapel, 1963) and in the northern Laramie Range 12-110 ft thick (Faulkner, 1950; Imlay, 1980). The member was recognized on the eastern flank of the Bighorn Mountains by Imlay (1952a). On this side of the Powder River Basin the member is about $55 \mathrm{ft}$ thick.

South of the Powder River Basin in the Laramie Range, the Stockade Beaver thins and becomes increasingly silty and sandy and grades laterally into the Canyon Springs (Imlay, 1947; Dresser, 1959; Pipiringos and O'Sullivan, 1976). To the west and northwest of the Powder River Basin, the Stockade Beaver thickens and limestone is a significant component of the member (Imlay, 1952a); farther west in southeastern Idaho, the Stockade Beaver correlates with the Leeds Creek Member of the Twin Creek Limestone (Imlay, 1980). The Stockade Beaver thickens north of the basin and is more limy and less silty. In Montana, the member is equivalent to the middle shaley part of the Rierdon Formation (Imlay, 1956; Peterson, 1957a). The northward increase in calcium carbonate might be the result of the Sheridan Arch influencing marine circulation and thus creating two separate temperature regimes in different parts of the sea (Peterson, 1954a).

The marine shale facies of the Stockade Beaver contains locally abundant marine fauna. Bivalves, ammonites (rare), crinoids, echinoderms, and ostracodes have been described from this facies (Imlay, 1947; Dresser, 1959; Wright, 1973; Wright, 1974a; Imlay, 1980). Within the Stockade Beaver, Meleagrinella curta, a small bivalve, is the most common fossil in the Black Hills and northern Laramie Range, and Gryphaea nebrascensis, an oyster, is the most common fossil in the northern Bighorn Mountains (Wright, 1973). Imlay (1980) reported that the Stockade Beaver is late Bathonian in age.

The marine shale facies of the Stockade Beaver was deposited in offshore areas of the early Sundance sea. The coarsening-upward facies of the member was deposited in 

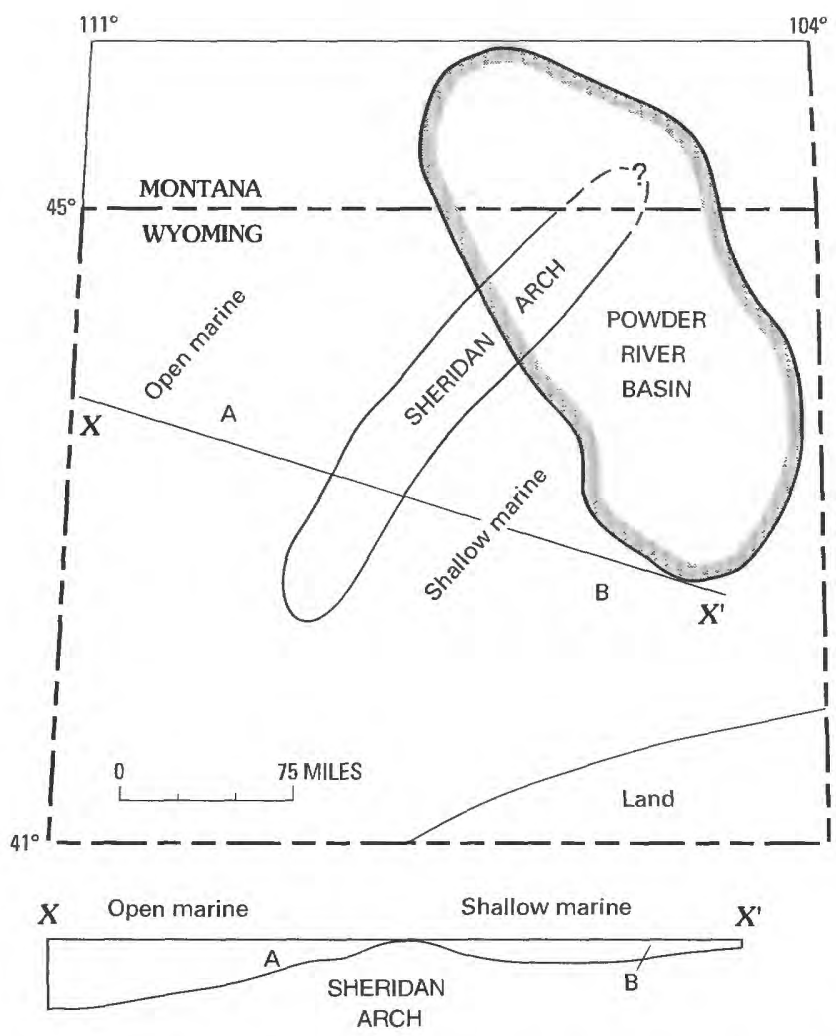

Figure 13. Effects of shoaling in vicinity of Sheridan Arch on distribution of certain bivalves and ostracodes in early Sundance sea in relation to present-day Powder River Basin. Assemblage A: Gryphaea nebrascensis (bivalve) and Procytheridea exempla (ostracode); assemblage B: Meleagrinella curta (bivalve) and Aparchitocythere compressa (ostracode). Modified from Peterson (1954b) and Wright (1973).

shallower water and, in most areas, represents the transitional zone into the overlying shallow-water deposits of the Hulett Sandstone Member of the Sundance Formation. The contact between the two members is drawn where sandstone exceeds shale. Thin sandstone beds in the coarseningupward facies of the Stockade Beaver probably represent sand transported offshore during storm activity. In the southern part of the Black Hills, Rautman (1976a) reported northeast-trending ripple crests that are probably subparallel with the shoreline of the early Sundance sea. Imlay (1947) reported that the source area for detritus was to the east and southeast.

Peterson (1958) stated that the barrier effect of the subaqueous Sheridan Arch is documented by thinning of the Stockade Beaver over this structure; the member is only 15 $\mathrm{ft}$ thick in the vicinity of the structure but thickens north and south away from the crest (Peterson, 1954b). Moreover, Peterson (1958) mentioned that the structure probably separates ostracode biofacies. The Sheridan Arch may also have influenced the distribution of certain bivalves in Wyoming; for example, Meleagrinella curta is dominant south of this structure, and Gryphaea nebrascensis is dominant north of the structure (fig. 13).

\section{Regressive Nearshore Sandy Rocks}

As the early Sundance sea continued to withdraw, shallow marine conditions prevailed in the area of the Powder River Basin, and the Hulett Sandstone Member of the Sundance Formation was deposited. The member was named by Imlay (1947) for exposures on the northern side of Bush Canyon about 3 miles north of Hulett, Wyoming. The Hulett consists of a sequence of thin- to thick-bedded sandstone (or sandy siltstone) and variable amounts of interbedded shale (fig. 14). The sandstone is light yellowish gray to light greenish gray, calcareous, well sorted, and very fine to fine grained and contains sparse oolites and glauconite. Grains are subangular to rounded and commonly frosted. Ripple laminations and cross-stratification are common. Symmetrical ripples are abundant, especially in the lower part of the member, and their crest lines trend northeast (Dresser, 1959; Rautman, 1976a). Bioturbation, burrows, and tracks and trails have been observed. According to G.N. Pipiringos (U.S. Geological Survey retired, oral commun., 1989), the trail Gyrochorte is particularly well represented. The interbedded shale is greenish gray, calcareous, silty or sandy, and fissile. In the northern Laramie Range, Dresser (1959) reported two occurrences of external molds of salt crystals in the Hulett, and Jenkins (1950) and Dresser (1959) noted that locally gypsum is present near the top of the member. Pipiringos and O'Sullivan (1976) also reported gypsum in this member in the same region. Fossils are rare and generally limited to internal molds of pelecypods. The sandstone is resistant, and the unit forms a series of small ledges in most places.

In the area of the Powder River Basin, the lower contact of the Hulett with the Stockade Beaver is conformable and gradational. The upper contact of the Hulett with the Lak Member of the Sundance Formation is conformable and gradational through several inches to a few feet. Toward the north on the east flank of the Bighorn

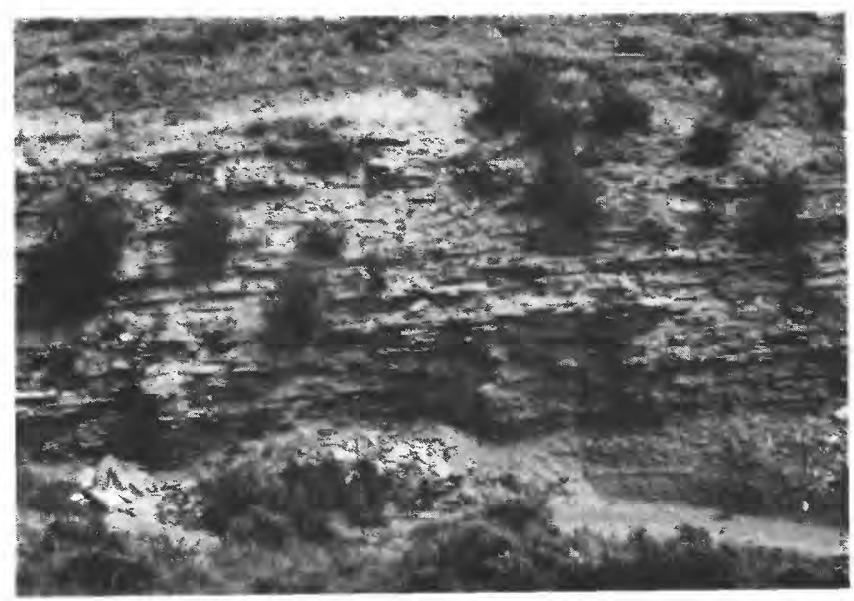

Figure 14. Hulett Sandstone Member of the Sundance Formation, southwest of Douglas, Wyoming, northern Laramie Range. 
Mountains, the Lak pinches out and the Hulett lies unconformably(?) below the Pine Butte Member of the Sundance Formation. Distinguishing these two members can be difficult where this juxtaposition occurs.

In the Black Hills, the Hulett thins southeastward and is 16-121 ft thick (Imlay, 1947; Rautman, 1978). The member thins toward the southeast in the Laramie Range (Pipiringos, 1968) and, in the northern end of the range, is 6-25 ft thick (Dresser, 1959). Peterson (1954a) reported that the Hulett on the eastern flank of the Bighorn Mountains thickens southward from 10-15 ft near Buffalo, Wyoming, to 50-75 ft near Mayoworth, Wyoming. From Buffalo northward, the member presumably thickens. South of Mayoworth, the Hulett thins, and, near Alcova, Wyoming, the member is only $5-10 \mathrm{ft}$ thick. The member thins to a wedge edge in the eastern Freezeout Hills west of Alcova and is absent farther south.

In the Laramie Range, Dresser (1959) and Pipiringos and O'Sullivan (1976) reported that the Hulett thins southward. The member thins and becomes more limey northwest of the Powder River Basin. On the western flank of the Bighorn Mountains, Stone and Vondra (1972) described the Hulett as a sequence of lenticular beds of trough cross-stratified, oolitic calcarenite (oolitic limestone of Peterson, 1954). Farther west, the Hulett correlates with the Giraffe Creek Member of the Twin Creek Limestone in southeastern Idaho (Wright, 1973). Imlay (1952a) identified the Hulett near the Montana-Wyoming State line on the eastern flank of the Bighorn Mountains and correlated the member with the upper part of the Rierdon Formation in Montana (Imlay in Richards, 1955; Imlay, 1956, 1980). Peterson (1954a) described a pebbly, coquinoid limestone bed less than $5 \mathrm{ft}$ thick at the top of the Hulett on the eastern flank of the Bighorn Mountains that is a distinctive ledgeforming bed at the top of the Rierdon in Montana. Farther north, the unit grades laterally into chalky limestone (Imlay, 1980). Imlay (1980) assigned an age of earliest Callovian to the Hulett.

The most complete environmental interpretation of the Hulett is by Rautman (1976b, 1978). According to Rautman, the Hulett in the northern Black Hills displays a complete coarsening-upward shoreface sequence as thick as $98 \mathrm{ft}$ consisting of a lower shoreface, upper shoreface, and foreshore. Locally, tidal channels are cut into the shoreface sequence. Lagoonal rocks and isolated washover-fan deposits lie above the foreshore unit. Rautman believed that the Hulett in this part of the Black Hills represents a northeast-trending barrier island complex. Only the lagoonal deposits extend into the southern part of the Black Hills, and Rautman interpreted the 16-20 ft of Hulett in this area to represent a tidal flat that existed south of the barrier island complex. In the Laramie Range, Rautman reported that the Hulett consists of two parts: a lower coarseningupward sequence that he believed represents an offshore bar deposit parallel with the northeast-trending shoreline and an upper sequence of siltstone, silty shale, and silty sandstone that he believed represents a deeper water environment seaward of the offshore bar deposits. This upper part of the Hulett is the only facies represented north and west of the Laramie Range.

The northeast-trending ripple crests reported by Dresser (1959) and Rautman (1978) are consistent with measurements I made and probably record the orientation of the shoreline. Most workers report symmetrical ripples in the Hulett and attribute them to oscillation, but Dresser (1959) noted the existence of some asymmetrical ripples that he attributed to currents approaching from the north or northwest. Rautman (1976a) stated that low-angle crossstratification in the foreshore deposits of the Hulett in the northern Black Hills indicates northward paleocurrent movement. Imlay (1947) postulated an easterly source area for detritus in the Hulett; Rautman (1975) specified a northeasterly source for this material.

According to Peterson (1954a), the Hulett is particularly well developed in areas adjacent to Jurassic positive structural elements because of shoaling conditions. For example, over the Sheridan Arch the member thins to $10 \mathrm{ft}$ but thickens north and south of the structure. In areas remote from these positive elements, the member is less well developed.

\section{Paralic Silty Rocks}

The Lak Member of the Sundance Formation was the last unit associated with the early Sundance sea to be deposited in the southern part of the Powder River Basin. Despite a wide areal distribution over much of Wyoming (more than $7,000 \mathrm{mi}^{2}$ ), the origin of the member remains problematic. Imlay (1947) named the Lak for exposures on the western side of Stockade Beaver Creek 5 miles northeast of Newcastle, Wyoming. The name comes from the Lak reservoir located on the L.A.K. ranch. "Sundance red" is a term commonly applied to this member, especially in the subsurface.

The lithology of the Lak varies considerably; in general, it consists of reddish massive siltstone. It also contains varying amounts of poorly sorted sandy siltstone and silty, very fine grained sandstone. Sand grains are subangular to rounded and commonly frosted. Fine-grained sandstone is present locally, and Imlay (1947) reported some medium-grained sandstone in the southern Black Hills. Also in the Black Hills, Robinson and others (1964) described the Lak as containing green shale interbeds in the upper 5-10 ft of the unit. Reported colors include shades of pink, maroon, red, orange, brown, and gray. Green or white diagenetic blotches are present locally. In the Laramie Range, Pipiringos (1968) noted that the Lak loses its reddish tone toward the south and is almost white. Although primary sedimentary structures are not common in the Lak, faint, irregular to wavy, discontinuous bedding and 
laminations are rarely present. No body or trace fossils have ever been described from the Lak. The Lak is weakly cemented and therefore poorly exposed; the member forms reddish slopes above the Hulett. In the northeastern part of the Laramie Range, bedded gypsum has been reported at the base of the Lak (Jenkins, 1950). Rautman (1976a) also reported gypsum in this member. In addition, external molds of salt crystals have been described at some locations (Dresser, 1959). G.N. Pipiringos (written commun., 1990), however, believed that any gypsum or salt molds described in the Lak are probably actually in the topmost part of the Hulett.

In areas marginal to the Powder River Basin, the lower contact of the Lak with the Hulett is always conformable and gradational over as much as several feet. Locally, the two members intertongue (Dresser, 1959, Rautman, 1976a). The upper contact with the Pine Butte can be gradational, with local interfingering, or sharp; where gradational the contact is probably conformable, but where sharp an unconformity might exist.

The Lak changes thickness over relatively short distances in the Black Hills and has an inverse thickness relation with the underlying Hulett (Robinson and others, 1964). Reported thicknesses of the member are 26-100 ft (Burma, 1941; Imlay, 1947). In the Laramie Range, the Lak thins southward. Reported thicknesses in the northern end of the range are 23-97 ft (Burma, 1941; Schwarberger, 1959). The Lak evidently thins northwest of the Laramie Range, and the only reference to this member in the Bighorn Mountains is that by Woodward (1957), who described $6 \mathrm{ft}$ of the unit near Arminto, Wyoming, at the extreme south end of the mountains.

In distribution, the areal extent of the Lak in central and eastern Wyoming forms a northeast-trending belt 100-150 miles wide. According to J.A. Peterson (written commun., 1990), the member can be traced in the subsurface east and northeast of the Black Hills. In the Laramie Range, the Lak thins southward. The Lak was probably deposited on the northeastern margin of the Entrada erg, and Peterson (1955, 1957a) and Imlay (1980) believed that the Lak is equivalent to the Entrada Sandstone of northwestern Colorado and Utah. The Lak is also equivalent to the Preuss Formation in southeastern Idaho (Peterson, 1957a). If gypsum is at the base of the Lak in eastern Wyoming, it possibly grades into the middle salt facies of the Preuss (Peterson, 1958). North 'of Kaycee, Wyoming, on the eastern flank of the Bighorn Mountains, the Lak disappears (fig. 15), possibly by lateral gradation into the oolitic sandstone and limestone in the upper part of the lower part of the Sundance (Peterson, 1954).

Imlay (1980) assigned an age of early to possibly middle Callovian to the Lak.

The depositional environment of the Lak is still open to debate; geologists cannot even decide whether the member is marine or nonmarine. If the Hulett is a nearshore

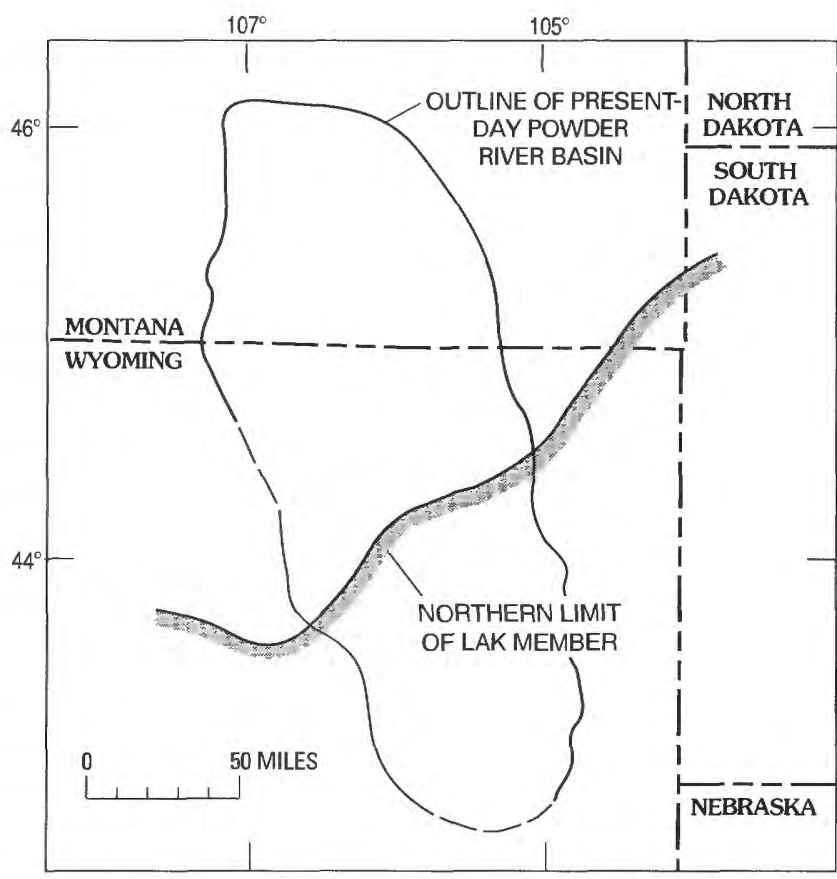

Figure 15. Approximate northern extent of Lak Member of the Sundance Formation in vicinity of Powder River Basin. Modified from Peterson (1958).

deposit, as most speculate, then a nonmarine setting for the Lak might be expected, and the red color of the deposits helps support this conclusion. The fine grain size and lack of any observable channel or interchannel deposits eliminates a fluvial environment. Some geologists think that the Lak is, at least partly, eolian, possibly a loess-type deposit. This interpretation is based on the Lak's silty content, scarcity of primary sedimentary structures, and absence of fossils. However, the silt in the Lak was deposited upwind from the sand in the Entrada erg, which seems to eliminate an eolian setting. Other geologists have suggested the Lak is a sequence of paleosols. Although soil profiles have not been described in the Lak, Wright (1973) noted the existence of iron nodules at the top of the member in the Freezeout Hills. A marine environment for the Lak is unlikely. Glauconite observed in the member by Wolcott (1967) in the southern Black Hills probably reflects the mineralogy of source rocks. Moreover, the lack of fossils and scarcity of primary sedimentary structures is incompatible with such a setting. A restricted-marine environment for the Lak has also been postulated. If the bedded gypsum and external molds of salt crystals that have been reported are actually in the Lak, then a hypersaline setting might be indicated. A restrictedmarine environment might explain the absence of body and trace fossils, but the scarcity of primary sedimentary structures remains unexplained. A sabkha environment for the Lak has also been suggested. The grain size, absence of body and trace fossils, weakly developed sedimentary structures, and possible occurrence of gypsum and salt 
molds are consistent with this setting. The Lak was deposited north of the Entrada erg and east of the evaporite deposits of the Preuss Formation. The existence of an erg to the south substantiates the needed aridity for a sabkha, and, if the evaporites in the Preuss represent a restricted-marine environment directly adjacent to the shoreline of the Jurassic seaway, then the regional setting of the Lak is consistent with a sabkha. Moreover, the vertical sequence of open marine (Stockade Beaver), nearshore (Hulett), and sabkha (Lak) is in order. Most likely the Lak was deposited under a variety of conditions.

Peterson (1958), in an attempt to explain the red color in a marine deposit, stated that perhaps all of the detritus in the lower part of the Sundance was originally red, but that decaying organic material in the sediment created reducing conditions that changed the color. If organic material was missing from the Lak deposits, as witnessed by the absence of fossils, the reducing conditions never developed and the sediments remained red. Imlay (1980), who also considered the Lak a very shallow, hypersaline, marine deposit, believed that the sediments in the member represent transported red lateritic soils from the Belt Island Uplift. Such an interpretation would require, however, that a lot of material be transported a long way from a relatively small area.

The Lak is present only south of the Sheridan Arch, and, during the final retreat of the early Sundance sea, this structure probably served as a submergent restricting barrier separating the depositional environment of the Lak to the south from open-marine conditions to the north (Peterson, 1958).

\section{Post-Piper Deposits of the Early Sundance Sea in Montana}

North of the Montana-Wyoming State line, deposits of the early Sundance sea that are equivalent to the lower part of the Sundance of Wyoming are referred to as the Rierdon Formation. The Rierdon is bounded conformably by the Piper Formation below and unconformably by the Swift Formation above. Cobban (1945) named the Rierdon for exposures in the vicinity of the Sweetgrass arch in western north-central Montana, and he included the unit as the middle formation of the Ellis Group. In the northern Bighorn Mountains, the Rierdon thickens toward the north and generally has a lower, middle, and upper part.

The lower part of the Rierdon commonly contains 0-15 ft of yellowish-gray, fine-grained, oolitic sandstone interbedded with gray to yellowish-gray, nodular to oolitic limestone. Some of these rocks are cross-stratified, and minor amounts of interbedded calcareous shale are locally present; regionally, sandstone in this part of the Rierdon increases toward the southeast (Imlay, 1956). These rocks probably represent the northern extension of the Canyon
Springs Sandstone Member of the Sundance Formation (Imlay, 1980). This part of the Rierdon is probably equivalent to Peterson's (1957) "Rierdon A" in the Williston Basin.

The middle part of the Rierdon, which represents the major part of the formation, consists of $110-160 \mathrm{ft}$ of yellowish-gray, calcareous clay shale. This interval contains abundant Gryphaea nebrascensis and is sandy in its top few feet. Based on the stratigraphic position of this shale and the presence of Gryphaea nebrascensis, this part of the Rierdon is probably equivalent to the Stockade Beaver Shale Member of the Sundance Formation. This part of the Rierdon is most likely equivalent to Peterson's "Rierdon B" in the Williston Basin.

The upper part of the Rierdon is a ledge-forming unit consisting of orangish-yellow, calcareous, very fine grained sandstone interbedded with gray, fossiliferous, oolitic limestone. The sandstone is commonly cross-stratified and ripple laminated and locally contains glauconite and oolites. The limestone, which generally is at the top of the sequence, is cross-stratified and locally contains glauconite. Sandstone dominates this part of the Rierdon in the northern Bighorn Mountains, but limestone increases to the west and is the dominant lithology in the Pryor Mountains in south-central Montana. In the northern Bighorn Mountains, this part of the Rierdon is $20-48 \mathrm{ft}$ thick, and thicknesses change over relatively short distances; regionally, this part thickens toward the southeast (Imlay, 1956). According to Imlay (1980), this part of the Rierdon represents the northward extension of the Hulett Sandstone Member of the Sundance Formation. These rocks are probably equivalent to Peterson's "Rierdon C" in the Williston Basin.

\section{Late Middle Jurassic Erosion}

The nature of the contact between the Lak and the Pine Butte is problematic. At some locations the contact is gradational and locally intertonguing and probably conformable; at other places it is sharp and possibly unconformable. Where the contact is sharp, the contrast between red siltstone of the Lak and gray sandstone of the Pine Butte is striking. Moreover, if the Lak is a nonmarine deposit, erosion probably occurred prior to deposition of the overlying marine Pine Butte. Conflicting evidence has resulted in some workers postulating an unconformity (Rautman, 1976a) and others doubting the existence of an unconformity (Specht and Brenner, 1979; Imlay, 1980). Pipiringos and O'Sullivan (1978) described an unconformity, which they designated the J-3, separating the Curtis Formation from the underlying Entrada Sandstone in the San Rafael Swell of central Utah and in the Uinta Mountains of northeastern Utah and northwestern Colorado. They reported that the unconformity is middle Callovian in age and that the duration of the erosional event was about one million years. Chert pebbles associated with the $\mathrm{J}-3$ are 


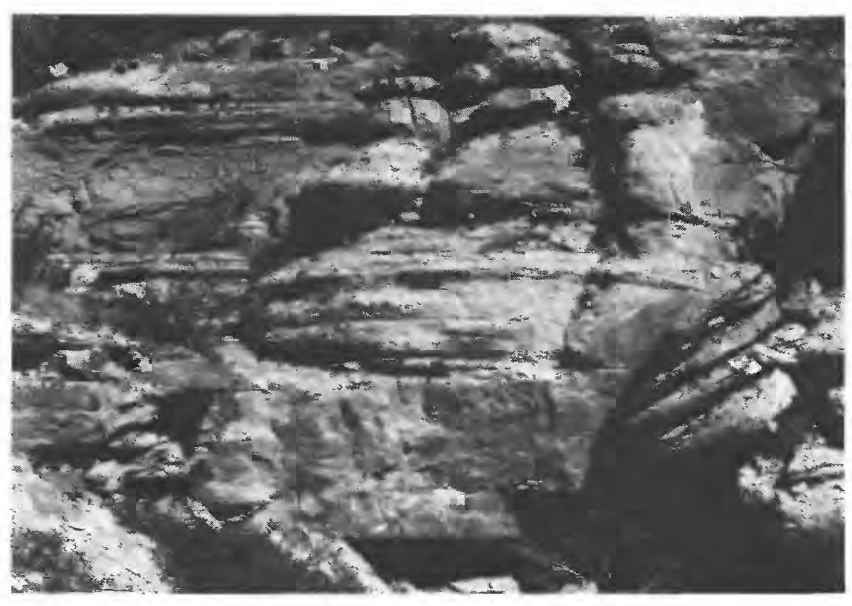

Figure 16. Pine Butte Member of the Sundance Formation southwest of Douglas, Wyoming, northern Laramie Range.

reported to decrease in size toward the northeast. The J-3 unconformity is at the same stratigraphic level as the Lak-Pine Butte contact. G.N. Pipiringos (oral commun., 1989) stated, however, that he does not consider the J-3 to extend into eastern Wyoming.

\section{The Pine Butte Sea}

Whether or not erosion followed deposition of the Lak, a rapid marine transgression occurred during late middle to early late Callovian time (Imlay, 1980) when the Pine Butte Member of the Sundance Formation was deposited in a very shallow sea in parts of eastern Wyoming and western South Dakota.

\section{Nearshore Sandy Rocks}

The Pine Butte Member was named by Pipiringos (1968) for outcrops of the unit near Pine Butte between Medicine Bow, Wyoming and the Freezeout Mountains. In south-central Wyoming, the Pine Butte consists of greenishwhite, thin-bedded, highly calcareous sandstone and interbedded siltstone and green shale. At some locations shale is the dominant lithology. The sandstone is commonly rippled and contains glauconite. Tracks and trails, especially Gyrochorte (Imlay, 1980), are common on bedding planes and the member is resistant and forms conspicuous ledges (fig. 16). In southern Wyoming, the Pine Butte is reported to contain 1-18 ft of red sandstone and siltstone in the middle of the member (Imlay, 1980). Fossils are not common in the Pine Butte, but echinoid spines and pelecypods have been reported.

The contact of the Pine Butte and Lak can be either gradational and locally intertonguing and represent a conformable boundary, or it can be sharp and possibly represent an unconformable boundary. The contact of the
Pine Butte with the overlying Redwater Shale Member of the Sundance Formation is sharp and unconformable.

Measured sections included in U.S. Geological Survey Bulletins of quadrangles on the western flank of the Black Hills do not show a sandy unit at the stratigraphic level of the Pine Butte. However, according to Pipiringos (1968) and Imlay (1980), the Pine Butte is present in the Black Hills, although it was not described in this area until G.N. Pipiringos recognized it in 1964. The member is 5-32 ft thick in the Black Hills and is thickest near Spearfish, South Dakota. The Pine Butte was also recognized and described in the Black Hills by Wright (1971) and Rautman (1976a). Pipiringos and O'Sullivan (1976) showed the Pine Butte in the Laramie Range to be 18-77 ft thick. In the north end of the range, the Pine Butte is about $38 \mathrm{ft}$ thick.

The Pine Butte continues south in the Laramie Range and is truncated by the sub-Morrison unconformity (J-5) just north of Boulder, Colorado (Pipiringos and O'Sullivan, 1976). The Pine Butte is stratigraphically equivalent to the Curtis Member of the Stump Sandstone of northeastern Utah. West of the Powder River Basin, the Pine Butte thins and pinches out near Lander, Wyoming. Along the eastern flank of the Bighorn Mountains, north of the Lak pinch out, the Pine Butte rests on the Hulett and distinguishing these two members can be difficult.

Imlay (1980) considered the Pine Butte to be middle Callovian in age.

Most geologists (for example, Imlay, 1980) consider the Pine Butte to represent the nearshore deposits of a separate and distinct marine invasion. In this sense, the Pine Butte and Redwater would have the same relation as the Canyon Springs and Stockade Beaver. Both J.E. Fox (oral commun., 1989) and T.S. Ahlbrandt (oral commun., 1989) stated that in the Black Hills some outcrops of the Pine Butte show eolian characteristics. The member also shows eolian features in Colorado north of Boulder (F. Peterson, written commun., 1990).

\section{Latest Middle Jurassic Erosion}

As the Pine Butte sea withdrew, a period of regional erosion followed that is now represented by an unconformity, named the J-4 unconformity by Pipiringos and O'Sullivan (1978), separating the Pine Butte from the overlying Redwater or, in areas where the members of the Sundance are not designated, separating the lower part of the Sundance from the upper part of the Sundance. The marine regression that caused the unconformity might be detected on the proposed Jurassic sea-level curve of Hallam (1988). In Montana, the J-4 unconformity separates the Rierdon from the overlying Swift Formation. The boundary is sharp and disconformable and generally shows no erosional relief; however, the lithology and fauna, particularly the sudden appearance of abundant belemnites, 
abruptly change at the contact. Pipiringos and O'Sullivan (1978) considered this erosional event as late Callovian in age and believed it lasted about two million years. Imlay (1980) reported that in some areas the Pine Butte is truncated by $\mathrm{J}-4$ erosion.

\section{The Late Sundance Sea}

The marine invasion that followed the $\mathrm{J}-4$ erosional event was the most extensive such transgression to affect the area of the Powder River Basin during the Jurassic (fig. 17). Deposits of the late Sundance sea are more extensive than any of the older Jurassic marine rocks in the middle Western Interior (Imlay, 1980). Although still relatively shallow, water depth was greater than in previous Jurassic seas, and structures such as the Sheridan Arch that were just barely submergent during earlier marine invasions were well below wave base (Peterson, 1954a). Regionally, the marine event began in the latest Callovian and, in the middle Western Interior, lasted until the early middle Oxfordian. Beginning in the early Oxfordian, the Redwater Shale Member of the Sundance Formation was deposited in eastern Wyoming and western South Dakota. Equivalent rocks in the Williston Basin are included in the Swift Formation.

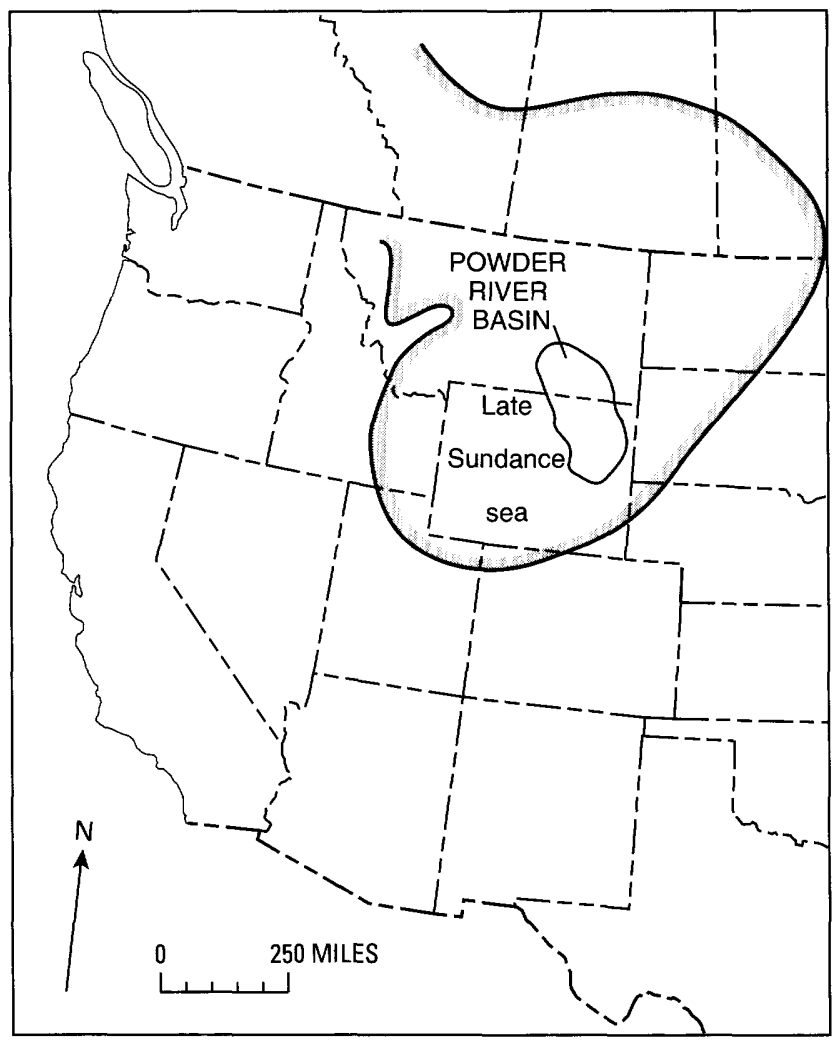

Figure 17. Approximate maximum areal extent of Oxfordian late Sundance sea in Western Interior. Modified from Brenner (1983).
For the first time in the Phanerozoic, the major source area for siliciclastic detritus in a marine deposit of the Western Interior was to the west. This was the beginning of a depositional trend that would last until the end of the Cretaceous.

An isopach map of strata deposited in the late Sundance and Windy Hill seas in the Wyoming part of the Powder River Basin constructed from subsurface data is shown in figure 18 (J.E. Fox, unpub. data base, 1990); thicknesses are $30-210 \mathrm{ft}$. The most prominent feature is the northeast-trending Gillette high in the central part of the basin. In the northwestern corner of the map, an easttrending thin zone might represent the Sheridan Arch. Southward thinning of deposits of the late Sundance sea is apparent in the southeastern corner of the map. Based on the abundance of arenaceous Foraminifera, Wright (1973) suggested that this sea may have been somewhat cooler than the early Sundance sea.

\section{Offshore Shaley Rocks}

The Redwater was named by Imlay (1947) for exposures near Redwater Creek, 9 miles northwest of Spearfish, South Dakota. Cobban (1945) named the Swift for exposures near the Swift Reservoir in northwestern Montana.

The Redwater is a marine deposit consisting of a complex sequence that may include shale or mudstone, siltstone, sandstone, and coquinoid sandstone or coquinoid limestone (biosparites of Zeiner, 1974). In general, the member coarsens toward the west (Imlay, 1947; Downs, 1949; Brenner, 1973). The member is characterized by abundant glauconite that sets it apart from older Jurassic marine units that contain only sparse amounts of this mineral. Fenner (1961) observed that glauconite and other heavy minerals, especially biotite, are most common in the lower part of the member. In addition, the member is locally calcareous and generally contains abundant belemnite tests that are commonly found scattered on the surface of outcrops. Many belemnites are water worn and when observed on bedding planes appear to be aligned as if by water currents. Wright (1973) listed Camptonectes bellistriatus as the most common bivalve in the coquinas.

In the Black Hills, the Redwater consists of greenishgray, fissile shale containing limestone concretions and minor light-gray, calcareous, fine-grained sandstone. The sandstone is present as discontinuous laminae and very thin beds in the lower and upper parts of the member. In addition, thin beds of oolitic, coquinoid limestone are in the upper part of the member, and an interval of glauconitic sandstone is common in the lower part of the member (Imlay, 1947; Robinson and others, 1964). In the Laramie Range, Pipiringos (1968) described the Redwater as having four parts: a lower siltstone, a lower shale, an upper siltstone, and an upper shale. Coquinoid limestone or 


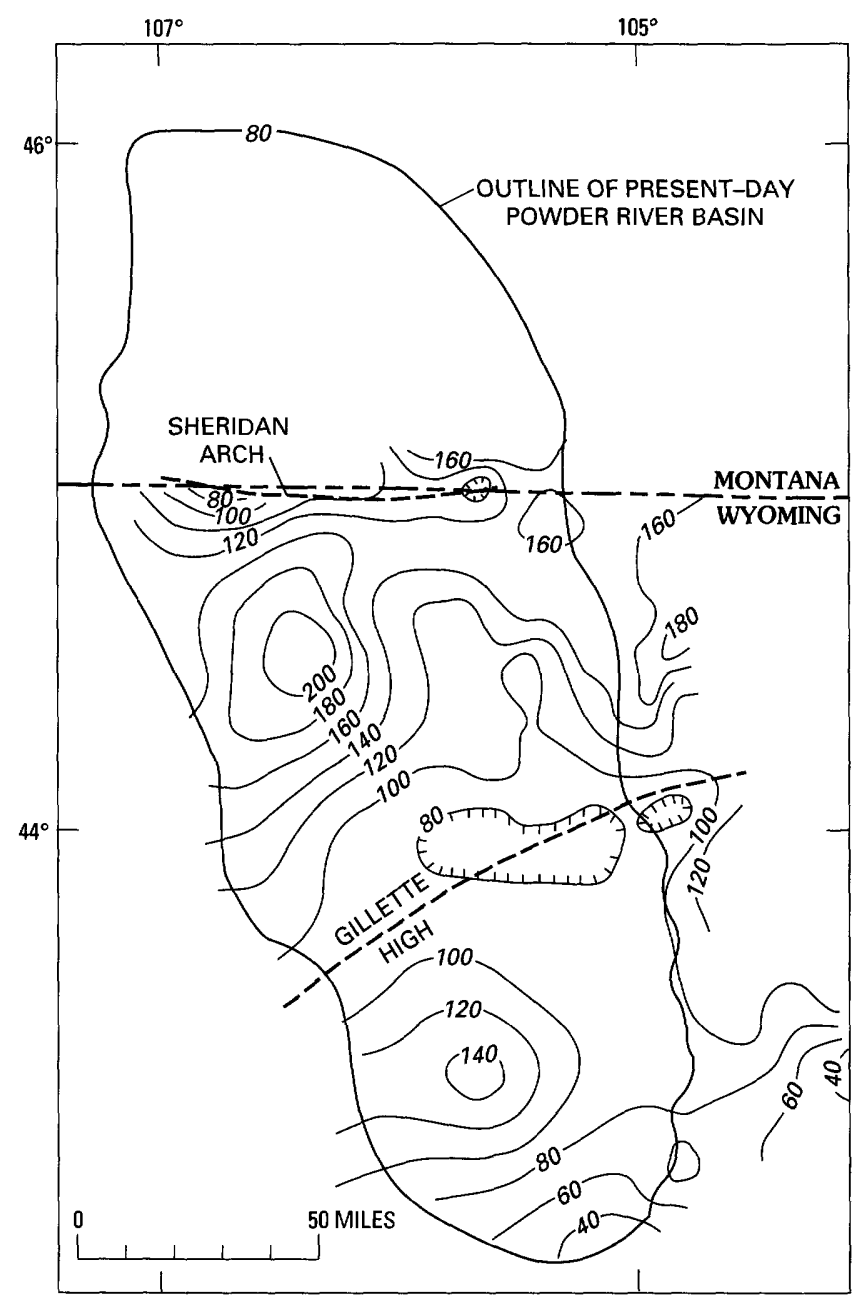

Figure 18. Isopach map of upper part of the Sundance Formation (Redwater and Windy Hill Members) in Wyoming part of Powder River Basin. Contour interval $20 \mathrm{ft}$. Dashed line represents thinning trend. Modified from J.E. Fox (unpub. data base, 1990).

coquinoid sandstone is in both of the siltstone units, and both shale units contain limestone concretions. Anderson (1978) discovered layers of bored limestone and layers of bored limestone cobbles that are locally truncated. He interpreted these features as evidence of subaerial exposure and local erosion resulting in minor disconformities within the member. In the Bighorn Mountains, Imlay (1980) reported that Pipiringos' four-fold division of the Redwater also applies. In the southwestern part of the Bighorn Mountains, Specht and Brenner (1979) described the Redwater as generally consisting of green mudstone and siltstone and thin beds of coquinoid limestone. Woodward (1957) in the same general area described a glauconitic, coquinoid limestone $6 \mathrm{ft}$ thick at the top of the member. In the Montana part of the Powder River Basin, the Swift, which is stratigraphically equivalent in part to the Redwater, was described by Imlay (1956) as consisting of a lower part containing gray, calcareous, glauconitic shale and abundant belemnites and a very glauconitic sandstone at the base (similar to that reported in the Black Hills) and an upper part containing gray, calcareous, glauconitic, fine- to coarsegrained sandstone. The sandstone is thin to thick bedded and is commonly cross-stratified. Locally, coquinoid limestone is present.

The contact of the Redwater (or Swift) with underlying rocks is sharp and unconformable. In some areas of south-central Wyoming where $\mathbf{J}-4$ erosion has removed the Pine Butte, the Redwater lies directly on the Lak (Pipiringos, 1968). Imlay (1947) reported that locally in the Black Hills some Lak material is reworked into the base of the Redwater. Where the Redwater is overlain by the Windy Hill Sandstone Member of the Sundance Formation, the contact is sharp and generally unconformable (Pipiringos, 1968; Imlay, 1980). Where the Morrison Formation overlies the Redwater or its equivalents, the contact is gradational and conformable. Where the Unkpapa Sandstone Member of the Morrison Formation overlies the Redwater, the contact is sharp and irregular.

Throughout the area of the Powder River Basin the Redwater generally thins toward the south. In the Black Hills, the member is $75-165 \mathrm{ft}$ thick (Imlay, 1980). The member is $64-161 \mathrm{ft}$ thick in the northern Laramie Range (Peterson, 1952; Pipiringos and O'Sullivan, 1976). In the Bighorn Mountains, Imlay (1980) reported that the member is $120-175 \mathrm{ft}$ thick, although thicknesses of more than $300 \mathrm{ft}$ have been reported (Peterson, 1952; Roy, 1960). In the southern Bighorn Mountains, the member is $82-118 \mathrm{ft}$ thick (Specht and Brenner (1979)). In southern Montana, Imlay (1956) reported that the Swift thickens toward the east and that in the northern Bighorn Mountains it is 85$190 \mathrm{ft}$ thick. A problem exists with published measurements of the Redwater (or its stratigraphic equivalents) in that one seldom knows whether the writer included unrecognized Pine Butte or Windy Hill in the total.

Toward the south in the Laramie Range, the four parts of the Redwater identified by Pipiringos (1968) are progressively truncated, top to bottom, by the J-5 unconformity at the base of the Windy Hill, and the Redwater is completely cut out at about the latitude of Chugwater, Wyoming. The projected zero edge of the Redwater intersects the northwestern corner of Nebraska (Pipiringos and O'Sullivan, 1976, 1978). Northwest of the Laramie Range, in south-central Wyoming, the lower siltstone and lower shale units in the Redwater grade into a slopeforming, impure sandstone sequence, and the upper siltstone and upper shale units grade into a cliff-forming, coquinoid sandstone or coquinoid limestone sequence (Pipiringos, 1968). West and southwest of south-central Wyoming, the Redwater is equivalent to the upper part of the Stump Sandstone (Imlay, 1980). According to Love and others (1945) and Pipiringos (1968), the upper part of the 
Redwater in eastern Wyoming is the same unit as a glauconitic sandstone in central Wyoming. This relation was also reported by Wright (1973). Imlay (1956, 1980) reported that east from the northern Bighorn Mountains the lower shaley part of the $S$ wift thickens at the expense of the overlying sandy part of the formation and that west from the northern Bighorn Mountains the upper sandy part thickens at the expense of the lower shaley part. Peterson (1957a) reported that sand increases in the Swift toward the west and that the formation grades into the Stump Formation in western Wyoming and southeastern Montana.

The transgression of the late Sundance sea began in the latest Callovian (Imlay, 1980). Imlay (1980) reported the Redwater to be early to early middle Oxfordian in age. Deposition of the Swift in Montana evidently continued after deposition of Redwater to the south had ceased; hence, the top of the Swift is slightly younger than the top of the Redwater. Imlay (1980) suggested that Swift deposition might have lasted into the late late Oxfordian or possibly even into the early Kimmeridgian in some areas.

The Redwater was deposited under open-marine conditions in a relatively shallow, epicontinental sea as indicated by the belemnite Pacytheuthis densus (Imlay, 1957) and various marine bivalves and ammonites (Imlay, 1980). Peterson (1954a) pointed out that the absence of limestone in the Redwater in the vicinity of the Powder River Basin might indicate cooler water than in previous Jurassic seas, especially south of the Sheridan Arch. The shoreline of the sea that deposited the Redwater has never been located because of removal during the J-5 erosion event. In areas north of south-central Wyoming the lower part of the member fines upward and records transgression, and the upper part coarsens upward and records regression (Brenner, 1973, 1983; Brenner and Davies, 1973). Although the stratigraphic level of this reversal is generally not apparent, Brenner and Davies (1974a) suggested that a zone of clayey mudstone commonly found in the middle of the member represents maximum transgression. Brenner (1973) identified three transgressive depositional environments of the late Sundance sea: (1) nearshore sand facies on the western margin of the seaway (adjacent to Belt Island Uplift), (2) muddy-marine platform facies seaward of the nearshore sands, and (3) mixed carbonate-clay platform facies on the eastern side of the seaway most distant from the sources of clastic input. According to Brenner, the lower part of the Redwater in northern Wyoming contains deposits of the muddy-marine platform facies. Many workers (for example, Brenner, 1973; Zeiner, 1974; Downey, 1986) attributed sandstone in the upper part of the Redwater to regressive offshore-bar deposits of a prograding shoreline (it is not known whether these workers included unrecognized Windy Hill in this sandy interval). Brenner (1973) assigned this part of the Redwater in north-central Wyoming to his regressive, marine bar sand facies. Most workers believe that the major source of clastic sediments in the Redwater of central Wyoming was to the west. As reported by Peterson (1957a), not only does the amount of sand in the member increase toward the west, but the grain size also increases in that direction. Moreover, Brenner (1973) mentioned that chert fragments, presumably weathered from Paleozoic rocks, increase toward the west.

The depositional environment of the coquinoid sandstone in the upper part of the Redwater Shale is problematic and in the Bighorn Basin has been hotly debated. The only common agreement is that high-energy conditions were required to accumulate the coarse material in the deposits. One school of thought believes that these bioclastic sandstones were deposited below sea level by tidal and storm-generated currents on and directly behind offshore sand ridges that sat on a shallow, low-energy, open-marine platform (Brenner and Davies, 1973, 1974; Specht and Brenner, 1979; Brenner and others, 1985). The other school believes that the same bioclastic sandstones were deposited near sea level by tidal currents in migrating north-south-trending tidal inlets that cut through an eastwest-trending barrier strandline on the northwardprograding shoreline (Uhlir and Vondra, 1984; Uhlir and others, 1986; Uhlir, 1987a; Uhlir and others, 1988).

\section{Early Late Jurassic Erosion}

In the middle Oxfordian, marine waters began regressing out of eastern Wyoming and adjacent areas in western South Dakota and withdrew to deeper parts of the late Sundance sea. The withdrawal of marine water allowed for a period of erosion lasting less than two million years (Pipiringos and O'Sullivan, 1978) that created an extensive peneplain. The resulting erosion surface, named the $\mathbf{J}-5$ unconformity by Pipiringos and O'Sullivan (1978), is at the base of the Windy Hill. The J-5 is a disconformity, and local relief on the surface is minor; however, Love and others (1949) mentioned a unit near Glendo, Wyoming, that seems to match the description of the Windy Hill, and they reported that it channels slightly into the underlying marine shale of the upper part of the Sundance. On a more regional scale, J-5 erosion in the Laramie Range progressively removed younger parts of the Redwater southward to a line at about the latitude of Chugwater, Wyoming, where the Windy Hill rests unconformably on the Pine Butte (Pipiringos and O'Sullivan, 1976). Farther south, the Pine Butte is cut out by this unconformity near Boulder, Colorado (Pipiringos and O'Sullivan, 1976). The same phenomena evidently occurred southwestward from the Black Hills (Pipiringos, 1968). Pipiringos and O'Sullivan (1978) stated that the J-5 unconformity is through much of the middle and southern Western Interior, and they believed that where the Windy Hill is absent the unconformity separates the Morrison or Ralston Creek Formations from older units.

In areas of the Powder River Basin where the Windy Hill Sandstone is absent, as in the Bighorn Mountains 
(Imlay, 1980), physical evidence to support an unconformity between the Morrison Formation and the Redwater Shale Member or Swift Formation is weak. Pipiringos and O'Sullivan (1978) cited thickness variations (3-234 ft) of the Swift as possible evidence of erosional relief at this stratigraphic level; however, many geologists (for example, Imlay, 1980; Uhlir, 1987a; J.D. Love, U.S. Geological Survey retired, oral commun., 1990) doubt the existence of an unconformity at this level.

\section{The Windy Hill Sea}

After the middle Oxfordian marine regression and subsequent $\mathrm{J}-5$ erosion interval, marine water rapidly transgressed back into parts of eastern Wyoming and western South Dakota. The sediments deposited by this final Jurassic marine invasion are named the Windy Hill Sandstone Member of the Sundance Formation. Pipiringos (1968) included the unit with the Sundance because of its marine origin. Prior to formal recognition, the unit was most commonly included in the Redwater Shale Member or, in areas where the members of the Sundance were not separated, in the top of the upper part of the Sundance. Because of the relative thinness of the member, it is generally mapped with the Redwater, upper part of the Sundance, or Morrison.

\section{Nearshore Sandy Rocks}

Pipiringos (1968) named the Windy Hill for exposures in the vicinity of Windy Hill near the Freezeout Mountains in southern Wyoming. The Windy Hill consists of thin-bedded, oolitic, calcareous sandstone; glauconite is present locally (Specht and Brenner, 1979; Brenner, 1983). In southeastern Wyoming the sandstone is orange to buff and fine to coarse grained and contains green to gray shale partings. In southern and central Wyoming, the sandstone is grayish white to brownish gray and very fine to fine grained. Calcite, oolites, and fossils increase toward the west. Silica in the form of chert, chalcedony, or clear quartz is in this unit throughout southeastern Wyoming (Pipiringos, 1957). Bedding planes are typically rippled, interference ripples being the most common. Outcrops of the Windy Hill generally form resistant ledges. Only a few publications mention the Windy Hill in the Black Hills (for example, Wright, 1971); however, a unit is commonly listed on stratigraphic sections in U.S. Geological Survey Bulletins of quadrangles that fits the description and stratigraphic level of the member. The unit, which is along the whole length of the uplift's western flank, is generally described as a yellow, calcareous, very fine grained sandstone or siltstone. In the northwestern part of the Black Hills, the unit commonly contains bedded gypsum, especially near the top. Bergendahl (1961) described a bed of gypsum $5 \mathrm{ft}$ thick at the top of the unit that can be traced along strike for about mile and a half. In addition, Robinson and others (1964) mentioned red and white and light-bluish-gray oolitic chert in the unit in beds $1-4$ in. thick.

The contact of the Windy Hill with the underlying Redwater is sharp and disconformable, but the contact is an angular unconformity when considered on a regional scale (Pipiringos and O'Sullivan, 1978). The upper contact with the Morrison Formation is conformable and gradational and locally intertonguing (Pipiringos, 1968; Zeiner, 1974; Pipiringos and O'Sullivan, 1978; Specht and Brenner, 1979; Brenner, 1983). The Windy Hill is also known to intertongue laterally with the Morrison in some areas (Pipiringos, 1957, 1968). Hence, the Windy Hill and basal Morrison are time-stratigraphic equivalents. This fact makes the Windy Hill more closely associated with the Morrison than with the Sundance, and some geologists suggest that the Windy Hill should be removed as a member of the Sundance and either defined as a separate formation or made a member of the Morrison.

The unit in the Black Hills that is probably equivalent to the Windy Hill thins toward the north. It is $10-14 \mathrm{ft}$ thick in the southern part of the uplift (Brobst, 1961; Epstein, 1961), and 2-7 ft thick in the northwestern part (Bergendahl and others, 1961; Robinson and others, 1964). Robinson and others (1964) stated that the unit can be as thick as $30 \mathrm{ft}$. In the southern part of Wyoming, the Windy Hill thins toward the northwest from 57 to $5 \mathrm{ft}$ (Pipiringos, 1968). In the northern end of the Laramie Range, it is 4-20 $\mathrm{ft}$ thick (Pipiringos and O'Sullivan, 1976). To the south, the Windy Hill crops out in the Colorado Front Range to about the latitude of Loveland. The member extends west of the Powder River Basin into northern Utah. Imlay (1980) reported that the Windy Hill is not present in the Bighorn Mountains; the member probably grades by facies change into the basal part of the Morrison.

Imlay (1980) cited middle Oxfordian as the age of the Windy Hill.

The Windy Hill is a shallow marine unit representing a separate and distinct marine invasion, and it was probably deposited under mostly regressive conditions (Specht and Brenner, 1979; Imlay, 1980). The gypsum reported near the top of the member in some areas probably represents the final deposits of the sea. The source area for much of the Windy Hill was probably in or near the Ancestral Rocky Mountains. The gypsum and chert beds reported in the member in the northwestern part of the Black Hills and local eolian characteristics observed by J.E. Fox (oral commun., 1989) and T.S. Ahlbrandt (oral commun., 1989) at several outcrops of the unit along the western flank of the uplift indicate that in this area the Windy Hill was probably deposited in an environment different from the shallowmarine setting in southern Wyoming. 


\section{Late Jurassic Alluvial Plain}

The retreat of the Windy Hill sea marked the end of the great Jurassic seaways in the Western Interior. As the Windy Hill sea withdrew, a vast expanse of sea floor was exposed that was then rapidly covered by alluvial sediments, now represented by the Morrison Formation, that spread from west to east (Brenner, 1983; Kocurek and Dott, 1983). For a time, alluvial sediments were being deposited in the west while marine sediments were still being deposited in the east (Downs, 1949; Zeiner, 1974).

\section{Continental Muddy Rocks}

The Morrisun crops out throughout the Western Interior from southern Canada to central New Mexico and from central Utah eastward to the Great Plains (Peterson, 1957a). Winslow and Heller (1987) reported the total area of Morrison deposition to exceed $617,600 \mathrm{mi}^{2}$. The Morrison's content of dinosaur bones (for example, Dinosaur National Monument) and uranium deposits (for example, Colorado Plateau) make it one of the most well known nonmarine formations in the United States. Eldridge (1896) gave the name Morrison Formation to the nonmarine rocks at the top of the Jurassic section near Morrison, Colorado. In the area of the Powder River Basin, the Morrison is defined as all of the Jurassic nonmarine rocks above the Sundance Formation.

In the area of the Powder River Basin, the Morrison generally is a fining-upward sequence composed of dull, variegated, gray, green, and red argillaceous rocks; some sandstone and limestone are in the lower part. Banding in the lower part of the formation is the result of alternating red and gray argillaceous rocks; the upper part of the formation contains mostly gray and green argillaceous rocks. The Morrison can generally be divided, independent of specific lithology, into a lower calcareous part and an upper noncalcareous part. The two parts are of variable thickness but are separated by a relatively sharp contact. The heavy mine al content of sandstone in the Morrison was studied by Mirsky (1961), Chisholm (1963), Mapel and others (1964), and Gott and others (1974). The most abundant heavy minerals are well-rounded zircon and tourmaline; 5-30 percent garnet is present. Chisholm (1963) noted the presence of two suites: a zircon-tourmaline suite in the lower part of the Morrison (95 percent well-rounded zircon and tourmaline and a minor amount of etched garnet that increases upward) and a garnet suite in the upper part of the Morrison (60 percent well-rounded zircon and tourmaline and 30 percent etched garnet).

The Morrison contains a variety of freshwater fauna including gastropods (such as Viviparus reesidei and Amplivalvata $\mathrm{sp}$.) and ostracodes (such as Theriosynoecum wyomingensis and Darwinula sp.). Calcareous fossils are generally only in the calcareous lower part of the formation.
Evidence of green algae in the form of charophytes (such as Latochara latitruncata and Praechara voluta) also is present. Waterworn bone and teeth fragments (mostly reptilian), polished pebbles interpreted by some workers to be gastroliths, and fragments of petrified wood are common (Tank, 1955; Sohn, 1958; Moberly, 1960; Szigeti and Fox, 1981).

In the Black Hills, the Morrison contains a basal eolian facies named the Unkpapa Sandstone Member that is discussed in detail in the following section. The main body of the Morrison in the Black Hills consists of gray, green, red, or purple mudstone, claystone, and siltstone. Where the Morrison is thickest, dark-gray argillaceous rocks are near the top of the formation. Locally, sandstone and limestone are in the lower part of the formation. The sandstone is light gray, calcareous, very fine grained, and commonly ripple laminated or cross-stratified and generally forms in lenticular bodies as thick as $10 \mathrm{ft}$. Sandstone bodies in the Morrison produce oil and gas in the Lance Creek field in the southern part of the Powder River Basin. The limestone is light gray, argillaceous, and microcrystalline and is present as nodules or as discontinuous beds from a few inches to as much as $4 \mathrm{ft}$ thick. Robinson and others (1964) described a particularly persistent bed of ledge-forming, wavylaminated, sandy limestone near the base of the Morrison throughout the northwestern part of the Black Hills. In addition, chert and barite nodules are in the uppermost part of the formation. Tank (1956) studied the clay minerals in the Morrison of the Black Hills and reported that the dominant minerals are illite and kaolinite; montmorillonite is rare.

The Morrison in the northern Laramie Range is similar to that in the Black Hills. In addition to the colors described in the Black Hills, lighter hues such as buff, cream, or yellow have been noted. Argillaceous rocks in the formation, generally referred to as shale, are more sandy than those in the Black Hills. Gray, calcareous, very fine to fine grained, lenticular sandstone bodies and thin, lenticular beds of gray, microcrystalline limestone locally are in the lower part of the formation (Love, 1958). Love described the local occurrence of thin-bedded, cherty limestone near the top of the formation.

In the southern Bighorn Mountains, Mirsky (1962a) stated that green mudstone is the most common rock type in the Morrison. Gray and red argillaceous rocks are also present, and dark-gray shale is near the top of the formation. MacClintook (1957) described this shale unit as 5-30 ft thick and containing local lignitic beds and layers of white analcime oolites. Mirsky also reported that very fine to medium-grained, thin-bedded, tabular sandstone bodies 5-10 ft thick grade laterally into mudstone in the lower part of the formation; very fine to coarse grained, locally conglomeratic, cross-stratified, lenticular bodies that average $15 \mathrm{ft}$ thick and have sharp, erosional bases are near the middle of the formation. The Morrison also contains 
minor limestone beds in the lower half of the formation that grade laterally into calcareous mudstone. This description of the Morrison in the southern Bighorn Mountains is similar to less detailed descriptions of the formation along the entire eastern flank of the mountains north into Montana.

The Morrison conformably overlies the Redwater or Swift or, where present, the Windy Hill. Where the Redwater or Swift underlies the Morrison, the contrast between fissile, glauconitic shale in the Redwater or Swift and blocky nonglauconitic mudstone in the Morrison is conspicuous. The contact between the Morrison and underlying units is relatively easy to pick and is generally described as sharp and conformable. Moberly (1960) reported, however, that in the northern Bighorn Basin the contact is somewhat erosional, and glauconite of the Sundance has worked up several inches into the basal beds of the Morrison. Downs (1949) and Mirsky (1962a) reported similar situations locally on the eastern side of the Bighorn Mountains. Spelman (1959) described a location in the northern Laramie Range where a channel sandstone in the Morrison cuts down into the Sundance. Where the main body of the Morrison overlies the Unkpapa, the contact can be conformable and gradational or unconformable and sharp.

The Morrison is overlain by the Cretaceous Lakota Formation in the Black Hills and by the Cretaceous Cloverly Formation in eastern Wyoming and southern Montana. This contact can be more difficult to pick than the lower contact. In the area of the Powder River Basin, the contact can be subtle and appear conformable where finegrained rocks (commonly carbonaceous) in the Lakota or Cloverly overlie the Morrison. The contact is sharp and erosional, however, where coarse-grained or conglomeratic, noncalcareous channel deposits of the Lakota or Cloverly have cut down through the fine-grained rocks in either formation and into the Morrison. Whether appearing conformable or erosional, the contact probably represents a disconformity.

In the Black Hills, Waage (1959) suggested placing the upper contact of the Morrison at the base of the lowest carbonaceous rock unit (basal deposit of the Chilson Member of the Lakota Formation) or, when this rock type is missing, at the base of the lowest conglomeratic sandstone (a conglomeratic sandstone in the Lakota). If both of these rock types are missing, the contact is placed at the top of the highest calcareous rock unit (uppermost Morrison). In central Wyoming, Love and others (1945) separated the Morrison from the overlying Cloverly based on the characteristics of sandstones. They observed that sandstone in the Morrison is generally dull and earthy and contains no conglomerate, whereas sandstone in the Cloverly is sparkly and clean and contains chert-pebble conglomerate. In the northern Bighorn Basin, Moberly (1960) suggested placing the contact at the base of the lowest bentonitic rock unit
(Little Sheep Mudstone Member of the Cloverly) or, where this rock type is missing, at the base of the lowest conglomerate (Pryor Conglomerate Member of the Cloverly or a conglomeratic sandstone in the Little Sheep). Carbonaceous shale is commonly described at the top of the Morrison and in the base of the Lakota and Cloverly. If it is true that all three formations can contain carbonaceous shale at this stratigraphic level, then a dark shale on dark shale contact is possible. Thus, discrepancies probably exist in the literature concerning the correct placement of this contact because dark shale observed near the contact might be in the top of the Morrison, in the base of the overlying formation, or both. The contact between the Morrison and overlying formations can also be picked based on heavy mineral content; garnet, common in the Morrison, decreases in the overlying formations. In addition, ostracodes and charophytes can be used as a guide where they are present (Sohn, 1958).

In general, the Morrison forms a clastic wedge that thins toward the east from as much as $800 \mathrm{ft}$ in northeastern Utah (Imlay, 1980) to a zero edge in the subsurface of western Kansas (Winslow and Heller, 1987) and western North and South Dakota (Anna, 1986). The formation also thins toward the north in Montana. The Morrison is known to be thicker in Late Jurassic basinal structures (Peterson, 1957a). Original thicknesses of the Morrison are difficult to determine because of uneven erosional beveling by the overlying Lakota or Cloverly. As a result of this beveling, the thickness of the Morrison changes abruptly over relative short distances. In Wyoming and western South Dakota, the Morrison generally is 125-370 $\mathrm{ft}$ thick (Imlay, 1980). Szigeti and Fox (1981) reported that the formation has an average thickness of $100 \mathrm{ft}$ in the Black Hills (less where the Unkpapa is present), and Mapel and Gott (1959) reported thicknesses of 70-120 ft ; Tank (1955), however, reported a maximum thickness of $223 \mathrm{ft}$. On the southeastern side of the Black Hills, the Morrison can be totally represented by the Unkpapa. In the southern Powder River Basin, Love (1958) reported that the Morrison is $150-220 \mathrm{ft}$ thick, but Faulkner (1950) reported that it is $264 \mathrm{ft}$ thick southwest of Casper, Wyoming, in the northern Laramie Range. In the southeastern Bighorn Mountains, MacClintook (1957) reported that the Morrison is about $195 \mathrm{ft}$ thick, and Mirsky (1962b) reported that it is 182-249 ft thick. Richards (1955) reported that it is $283 \mathrm{ft}$ thick in the northern Bighorn Mountains north of the Montana-Wyoming State line; this value is the greatest reported thickness for the formation in the area of the Powder River Basin.

Figure 19 is an isopach map of Morrison deposits in the subsurface of the Wyoming part of the Powder River Basin (J.E. Fox, unpub. data base, 1990); thicknesses are 60-210 ft. A zone of thin Morrison deposits trends northwest through the southern and central parts of the basin and veers to the northeast just north of Gillette, Wyoming. The patterns observed in this map result from the erosional 


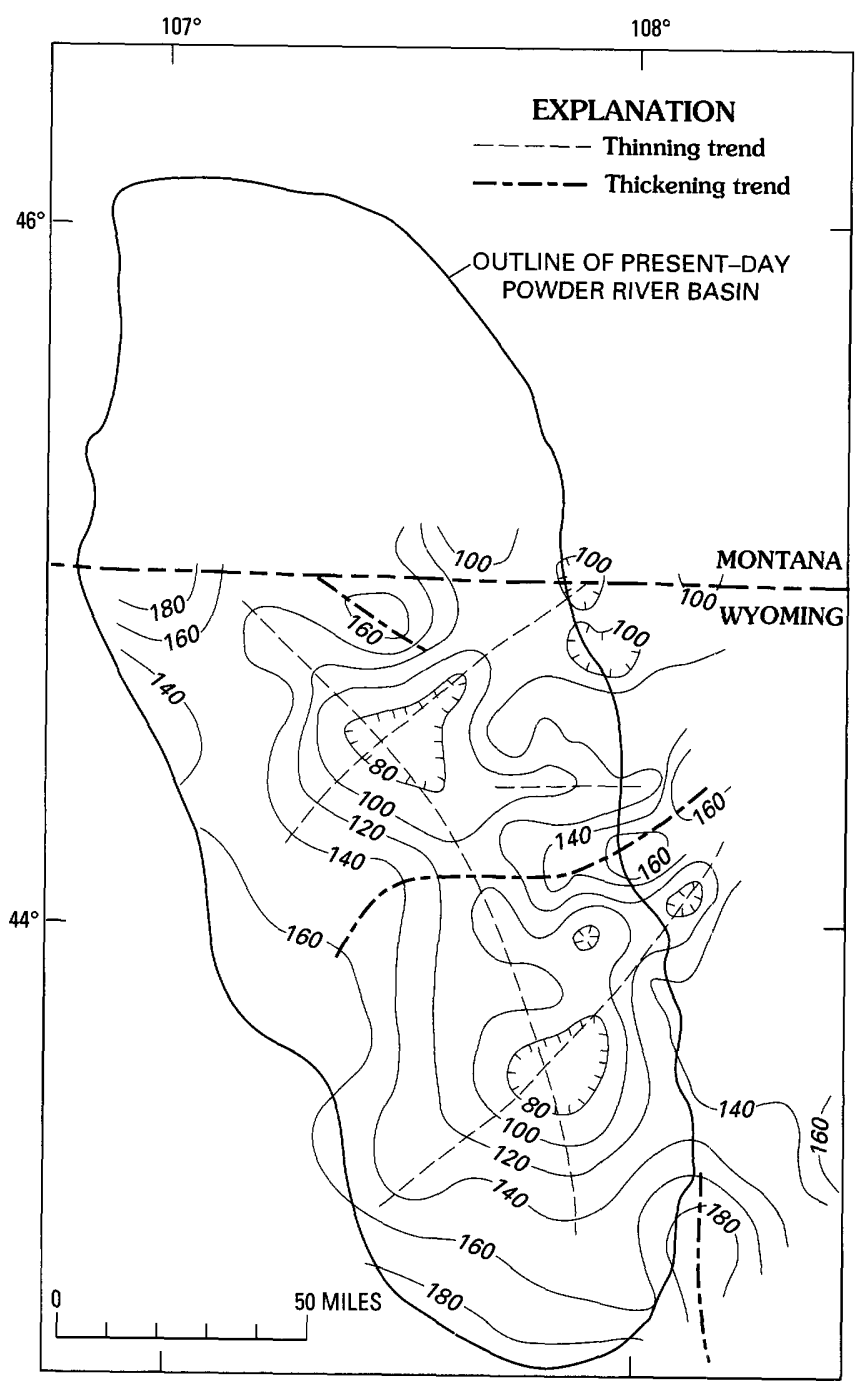

Figure 19. Isopach map of Morrison Formation in Wyoming part of Powder River Basin. Contour interval $20 \mathrm{ft}$. Modified from J.E. Fox (unpub. data base, 1990).

contact between the Morrison and the overlying Cretaceous rocks; the Morrison is thin where overlying Lakota or Cloverly fluvial channels have eroded the deepest. Thus, the observed patterns probably represent fluvial trends during earliest Cretaceous time.

The well-known members of the Morrison in the Colorado Plateau (for example, Salt Wash and Brushy Basin Members) have not been recognized north of western Colorado and Utah. However, based on the presence of the ostracode Theriosynoecum wyomingensis in the lower and middle part of the Morrison in the Black Hills, Sohn and Peck (1963) considered this part of the Morrison in this area to be a time-stratigraphic equivalent of the Salt Wash.

Deposition of the Morrison in the southern part of the Western Interior might have begun as early as the early Oxfordian and in the northern part of the Western Interior as late as the Kimmeridgian (Imlay, 1980). In the area of the Powder River Basin, deposition on the $\mathrm{J}-5$ erosion surface probably began in the late Oxfordian, and this time interval is represented in the Windy Hill or, where the Windy Hill is absent, in the deposits and minor unconformities in the lowest part of the Morrison (Brenner, 1983). Most of the Morrison probably is Kimmeridgian in age, although the upper part of the formation might extend into the Tithonian in some areas (Imlay, 1980).

During the Late Jurassic, increased tectonic activity associated with the Elko orogeny (Thorman and others, 1990) resulted in significant uplifts on the western edge of the Western Interior in Utah, Nevada, and Idaho and the development of a broad foreland basin to the east (fig. 20). The depositional axis of this basin shifted eastward during the Late Jurassic and Early Cretaceous (Kvale and Vondra, 1985). Uplifts on the western side of the basin provided a steady and abundant supply of siliciclastic sediments for distribution down a broad paleoslope that dipped gently to the northeast (Brenner, 1983; Kocurek and Dott, 1983; Winslow and Heller, 1987). The low dip of the Morrison paleoslope is indicated by the predominance of fine-grained rocks and by fluvial environments associated with highsinuosity streams. The direction of the paleoslope is supported by paleocurrent data. Evidence indicates that the Morrison was deposited on a relatively featureless surface. The initial eastward progradation of Morrison sediments occurred rapidly because almost no erosion occurred at the base of the formation; however, following the initial progradation, the remainder of the Morrison was deposited more slowly under stable tectonic conditions despite the active tectonism that was occurring to the west in the source area. One of the remarkable features of Morrison deposition is the vast expanse over which similar depositional conditions persisted.

The depositional environments of the Morrison include fluvial, with all the associated subfacies (channel, levee, crevasse splay, floodplain, and so on), lacustrine, and, in Montana, peat swamps. In the southern Bighorn Mountains, Mirsky (1962a) interpreted the tabular sandstone bodies in the Morrison to represent overbank-sandstone deposits such as crevasse splays and the lenticular sandstone bodies to represent channel deposits. According to Moberly (1960), gray and green argillaceous rocks of the Morrison were deposited in reducing environments such as shallow stagnant lakes and ponds, and reddish-brown argillaceous rocks were deposited in oxidizing environments such as levees and floodplains. Limestone in the lower part of the Morrison represents accumulation in shallow flood-basin lakes, some of which were at least mildly alkaline (Weiss and Wenden, 1965). Where the Windy Hill is present, rocks in the lowermost part of the Morrison were probably deposited in a paralic environment marginal to the retreating Jurassic seaway (see Kvale and Vondra, 1985). In the Colorado Plateau, the Morrison contains rocks that can be linked to volcanism to the west and southwest (Stokes, 1944; Owen and others, 1989). For the most part, such 


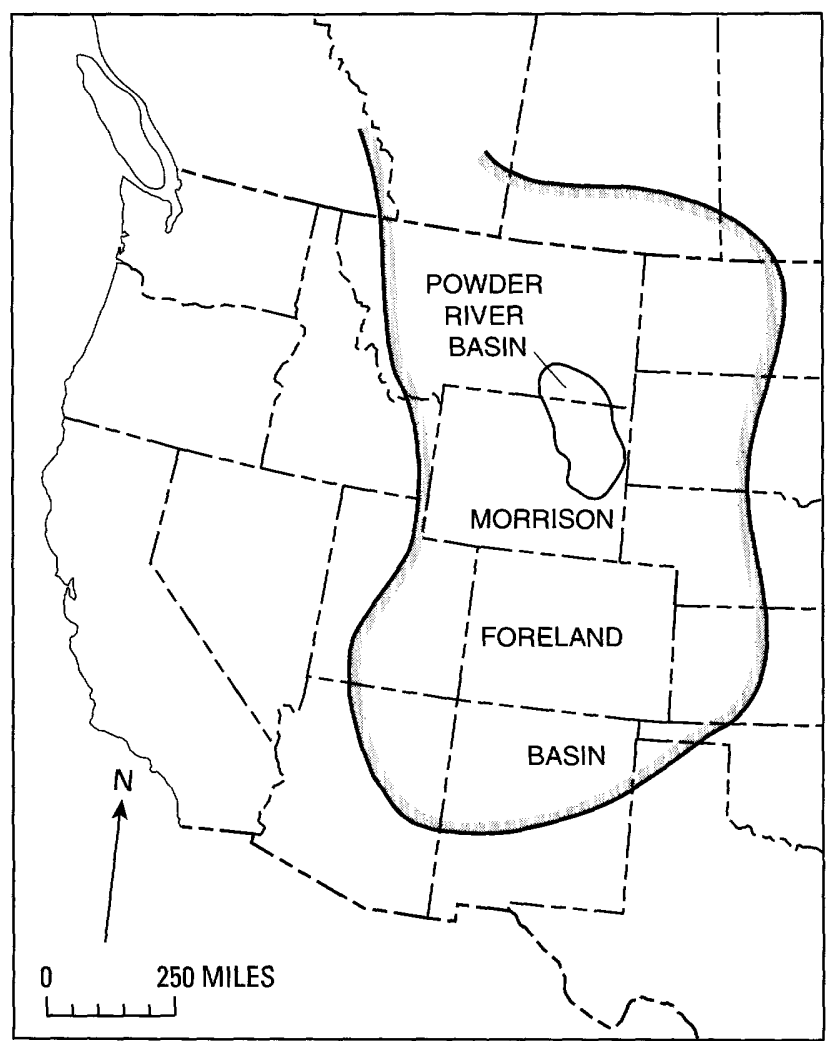

Figure 20. Approximate maximum areal extent of Morrison foreland basin in Western Interior. Modified from Winslow and Heller (1987).

evidence is lacking in Morrison rocks in the area of the Powder River Basin. Mirsky (1962a) and Winslow and Heller (1987) pointed out, however, that smectite is the dominant clay mineral in the upper part of the Morrison in the area of the Bighorn Basin; they attributed the smectite to the diagenetic alteration of volcanic ash. Mirsky (1962a) reported that some of the mudstone in the upper part of the Morrison in the southern Bighorn Mountains is bentonitic and probably also is an alteration product of volcanic material. In addition, MacClintook (1957) and Douglass (1984) in this same area described local beds of chalcedony and layers of analcime oolites in the upper part of the Morrison that might also have resulted from the alteration of volcanic material. In the Black Hills, beds of bluish-black chalcedony are in the Morrison, and a volcanic source for this silica has been postulated (Tank, 1955). The absence of significant quantities of volcanic debris in Morrison deposits and the absence of widespread fluvial sandstone bodies probably account for the lack of uranium mineralization in the formation in this part of the Western Interior.

The lower part of the Morrison was probably deposited under warm, arid to semiarid conditions; evaporites in the upper part of the Windy Hill and an eolian facies represented by the Unkpapa support this conclusion. The upper part of the Morrison, which contains mostly floodplain and lacustrine facies, was possibly deposited under cooler, more humid conditions. This climate change may be reflected in the division of the Morrison into a lower calcareous part and an upper noncalcareous part. A climate change during Morrison time is supported by Kocurek and Dott (1983), who pointed out that increased northward drift of the North American plate in the Late Jurassic gradually moved the Western Interior into higher latitudes.

Winslow and Heller (1987) showed that Morrison streams in the Bighorn Basin flowed toward the eastnortheast. In the same basin, Moberly (1960) reported a similar average direction but stated that values vary from north to south. In the southern Bighorn Mountains, Mirsky (1962a) reported that paleocurrent directions were toward the east, consistent with measurements I obtained along the eastern flank of the mountains.

A western source for most Morrison sediments is indicated by fluvial paleocurrent data and is suggested by both regional thickening of the formation and an increase in the amount of sand in the formation toward the west. The mineralogy and clast composition indicate that the source area consisted mostly of sedimentary rocks. This conclusion is supported by the abundance of illite in the argillaceous rocks of the Morrison that presumably was weathered from marine shale. Further evidence of a sedimentary source is provided by the abundance of well-rounded zircon and tourmaline in the heavy-mineral fraction of sandstones in the Morrison (Moberly, 1960; Chisholm, 1963). The existence of some plutonic rocks in the source area is indicated by the presence of garnet; small amounts of augite, hornblende, hypersthene, biotite, and apatite might indicate minor volcanism in the source area (Chisholm, 1963). As pointed out by Kvale and Vondra (1985), some amount of sediments undoubtedly came from the craton east of the Morrison foreland basin.

\section{Eolian Sandy Rocks}

Following the withdrawal of the Windy Hill sea, large bodies of eolian sand accumulated locally on the freshly exposed marine surface. These bodies are now represented by eolianites in the basal part of the Morrison Formation. This facies is best developed on the eastern and southeastern flanks of the Black Hills, where the eolianites thicken at the expense of the main part of the Morrison and locally constitute the total thickness of the formation. Darton (1899) named these deposits the Unkpapa Sandstone and, because he considered them older than the Morrison, gave the unit formational status. Reeside (in Yen, 1952), Sacrison (1958), and Szigeti and Fox (1981) demonstrated, however, that the Unkpapa Sandstone is a contemporaneous facies of the main body of the Morrison, and Szigeti and Fox (1981) recommended lowering its status to that of a member of the Morrison. Based on the established relation between these two units, I consider the Unkpapa a member of the Morrison. 
The Unkpapa is composed of massive, friable, very fine to fine grained, well to poorly sorted, quartzose sandstone that contains some feldspar. Grains are subangular to subrounded and commonly frosted. Heavy minerals include well-rounded zircon, tourmaline, garnet, and leucoxene (Sacrison, 1958). On fresh surfaces the sandstone is almost white, but on weathered surfaces it is generally light yellow to light brown and in some places mottled or color banded red and purple (Liesegang rings). Small-scale faulting is particularly well displayed by offsets of these color bands. Faint, large-scale, high-angle cross-stratification is present locally, especially near the middle of the unit. At several locations, the Unkpapa contains considerable amounts of silt and clay near the top of the deposit (Sacrison, 1958; Post, 1967; Wolcott, 1967) that might represent a transitional facies into the main body of the Morrison.

The Unkpapa lies conformably above the Sundance. Where the Unkpapa is overlain by the main body of the Morrison, the contact is either conformable and gradational or disconformable and sharp with as much as several inches of erosional relief. Where carbonaceous rocks of the Lakota lie on the Unkpapa, the contact is conformable and gradational; where a fluvial channel in the Lakota has cut down into the Unkpapa, the contact is disconformable and sharp (Szigeti and Fox, 1981).

In general, the Unkpapa thins to the north and west, but the thickness of the unit varies greatly over relatively short distances. Szigeti and Fox (1981) reported that where the Unkpapa is thick the overlying main part of the Morrison tends to be thin. Wolcott (1967) stated that where the Morrison contains unusually thick Unkpapa, the formation can be two to three times as thick as nearby sections that do not contain Unkpapa. The maximum exposed thickness of the Unkpapa is $267 \mathrm{ft}$, but the unit is as thick as $300 \mathrm{ft}$ in the subsurface (Szigeti and Fox, 1981).

Numerous isolated sandstone bodies have been described in the basal part of the Morrison in areas of the Black Hills north of the Unkpapa zero edge (Tank, 1955; Sacrison, 1958). Some of these bodies are as thick as $150 \mathrm{ft}$ (Mapel and Pillmore, 1963a). The descriptions of these rocks commonly match the description of the Unkpapa, and the sandstone bodies are probably lithostratigraphic equivalents. Some isolated sandstone bodies in the basal part of the Morrison in central Wyoming (fig. 21) are also interpreted to be eolianites (Douglass, 1984; Uhlir, 1986; Uhlir, 1987a; Weed and Vondra, 1987) and probably are age equivalent to the Unkpapa of the Black Hills.

The Unkpapa has long been interpreted as an eolian deposit. Szigeti and Fox (1981) based their eolian interpretation partly on the occurrence of eolian-type crossstratification, lack of fossils and bioturbation, and the presence of frosted grains. The existence of discontinuous dune fields in this region of the Western Interior during Unkpapa time is consistent with the arid climate postulated

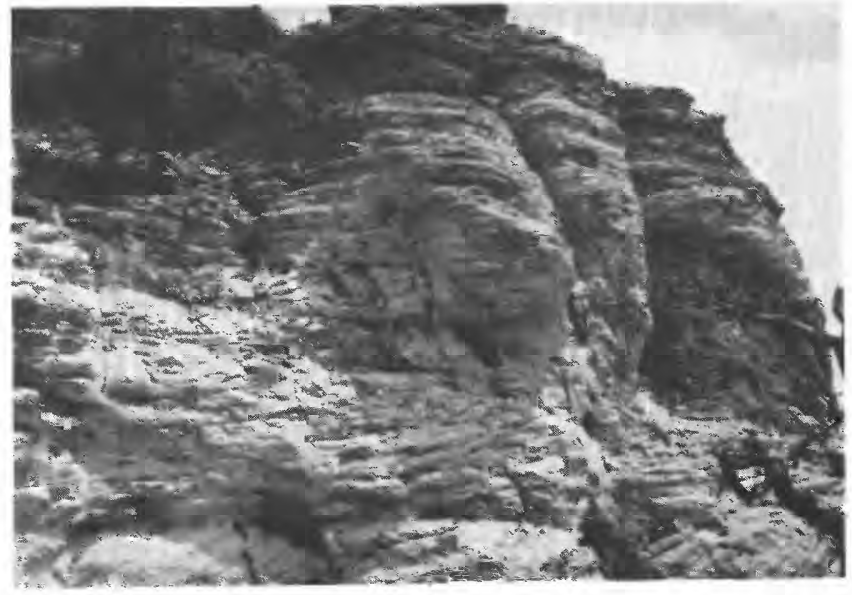

Figure 21. Eolian facies in lower part of the Morrison Formation, southeastern Bighorn Mountains. Hammer for scale.

for this time by Stokes $(1944,1950)$, Peterson (1972), and Kocurek and Dott (1983). Kocurek and Dott (1983) believed that the Unkpapa may represent the final expression of the great period of erg development that dominated the southern Western Interior earlier in the Jurassic. Deposits in central Wyoming equivalent to the Unkpapa Sandstone are interpreted to be eolianites based on eoliantype cross-stratification and the presence of nonmarine ichnofauna (Weed and Vondra, 1987).

In the Black Hills, rocks of the main part of the Morrison that lie stratigraphically adjacent to the Unkpapa consist of both fluvial and lacustrine deposits that accumulated in interdune areas. In the late part of Morrison time, increased vegetation resulting from the change to a more humid climate stabilized the Unkpapa dunes, and fluvial deposits of the main part of the Morrison overlapped the stabilized dunes in all but a few areas (Szigeti and Fox, 1981; Fox and Dandavati, 1982). In contrast to this model, Sacrison (1958) speculated that most of the main part of the Morrison stratigraphically adjacent to the Unkpapa was deposited under lacustrine conditions; most of the Unkpapa thus represents backshore-dune deposits, but some of the sand might have accumulated on lacustrine beaches or in the shallow-water margins of lakes. Blakey and others (1988) also postulated a lacustrine origin for the main part of the Morrison and suggested that regional subsidence caused the lacustrine deposits to transgress over the top of the associated dunes.

Uhlir (1987) and Weed and Vondra (1987) reported northward paleocurrent directions for the eolianites in central Wyoming. In the Bighorn Basin, Winslow and Heller (1987) showed that paleocurrent direction were to the west, but Douglass (1984) showed a northwest direction in the southern part of the basin. In the southern Bighorn Mountains I obtained northeastward measurements. This discrepancy might be explained by F. Peterson (1988), who 
stated that in the Wyoming-South Dakota part of the Western Interior paleocurrent measurements from these deposits are too variable to show a consistent trend.

The source of the sand in the Unkpapa was probably sedimentary rocks exposed in minor positive structural elements to the east and southeast of the Black Hills beyond the Morrison zero edge. The heavy mineral content of the Unkpapa reported by Sacrison (1958) supports a sedimentary rock source. Szigeti and Fox (1981) thought that the source was sandstone in the lower part of the Sundance exposed along the Chadron Arch southeast of the Black Hills in northwestern Nebraska. Presumably sand weathered from these exposures was either blown north and deposited as a linear belt of dunes extending from the source area to the Black Hills (Fox and Dandavati, 1981) or was transported north by streams and subsequently reworked by eolian processes (F. Peterson, 1988). Peterson also suggested a more detailed variation of this history. He postulated that, near the end of Sundance time, sand from Nebraska was fluvially transported northwestward to the edge of the Windy Hill sea and then distributed northward by longshore drift. The sand was then blown eastward by a west wind either directly from the beach of the Windy Hill sea or later, following lithification and the withdrawal of the sea, from eroded sandstone of the Windy Hill. In either case, the concentration of sand in the Unkpapa on the eastern and southeastern sides of the Black Hills might have resulted from a wind-shadow effect created by a west wind and an incipient Black Hills uplift. Uhlir (1986) and Weed and Vondra (1987) suggested that the sand in the eolianites of central Wyoming was derived from sandstone of the Windy Hill exposed in adjacent positive structural elements that were the precursor of later Laramide uplifts. They postulated that the sand accumulated on the downwind northern sides of these uplifts.

\section{Contact of the Jurassic and Cretaceous Systems}

The contact separating the Jurassic and Cretaceous Systems in the Powder River Basin has traditionally been placed between the Morrison and overlying Lakota or Cloverly. Most workers agree that a disconformity exists at this contact, and debate has focused on the duration of this hiatus. Based on the youngest reported age of the Morrison and the oldest reported age for an overlying formation (Ephraim Conglomerate), Pipiringos and O'Sullivan (1978) estimated that the disconformity represents about three million years.

In the Bighorn Basin, Winslow and Heller (1987) pointed out that the Morrison and overlying Cloverly were deposited by the same fluvial system. The observable differences between these two formations represent a relatively rapid change from meandering- to braided-stream deposition probably resulting from increased tectonic activity associated with the Sevier orogeny. This relation was recognized by many earlier workers, and the two formations are commonly mapped as a single unit (for example, Love and Christiansen, 1985). Winslow and Heller (1987) reported that a disconformity does separate the two formations, but that a single, widespread surface either does not exist or cannot be identified. Because similar disconformities exist in both the Morrison and Cloverly at the bases of fluvial channels and as weathered horizons within overbank sequences, the Morrison-Cloverly disconformity might be of minor significance.

\section{TECTONIC INFLUENCE ON SEDIMENTATION}

The area of the Powder River Basin is included in maps of regional lineaments published by Slack (1981), Maughan (1983), Marrs and Raines (1984), and Anna (1986). If one superimposes all of these trends onto one map, it is apparent that there is a line to match any stratigraphic or structural feature, and thus the usefulness of these lineament maps must be questioned. It is apparent, however, that two sets of lineaments are present-northwest trending and northeast trending. As observed on isopach maps of deposits of the lower part of the Sundance, upper part of the Sundance, and Morrison (figs. 11, 18, 19), zones of thick and thin deposits most commonly trend in one of these two directions.

Peterson (1957b), using regional thickness trends of various Jurassic units, established that incipient negative and positive structures existed during the Jurassic in the approximate positions of Laramide basins and uplifts (also see Mirsky, 1962a).

The northeast-trending Sheridan Arch, postulated to have existed in northeastern Wyoming during part of the Jurassic, can be identified on isopach maps of Jurassic rocks in the Wyoming part of the Powder River Basin as a linear trend of thin deposits. The best indication of this structure is in the northwestern part of the map of deposits of the lower part of the Sundance (fig. 11). Less impressive evidence of the structure is in the northwestern corner of the map of deposits of the upper part of the Sundance (fig. 18), and the zone of thick Morrison deposits observed in the northern part of the isopach map of that formation (fig. 19) might indicate that the Sheridan Arch served as a drainage divide during deposition of fluvial deposits in the Cloverly.

The existence of the Sheridan Arch as a submerged barrier during Sundance time (Peterson, 1954a, 1957b, 1958) is supported by the following observations.

1. The position of the Sheridan Arch probably limited the southern extension of the Bajocian Gypsum Springs sea because no deposits of this event have been found south of the structure. 
2. The Piper Formation, representing the first deposits of the Bathonian-Callovian early Sundance sea, has not been found south of the Sheridan Arch.

3. The more oolitic nature of some marine units in the lower part of the Sundance and in the Rierdon Formations in the vicinity of the Sheridan Arch indicates shoaling conditions.

4. The 50-percent sand line for deposits of the early Sundance sea rarely extends north of the Sheridan Arch, indicating that the structure served as an effective barrier to the northward migration of sand.

5. Shale in the Rierdon north of the Sheridan Arch is very calcareous, whereas equivalent shale in the lower part of the Sundance south of the structure is only mildly calcareous. The Sheridan Arch might have separated two separate systems of marine circulation and thus two separate temperature regimes.

6. The Sheridan Arch separates two ostracode biofacies deposits in deposits of the early Sundance sea.

7. Limitation of deposits of the Lak Member of the Sundance to areas south of the Sheridan Arch indicates that a shallow-water or terrestrial environment existed south of the structure.

It is interesting to note that descriptions of Jurassic marine rocks change from typical Sundance to typical Ellis Group at about the position of the Sheridan Arch. The big question is was the Sheridan Arch ever exposed above sea level during the Middle or Late Jurassic?

The Bell Fourche Arch of Slack (1981) and the Gillette High shown in the isopach maps of deposits of the lower and upper parts of the Sundance (figs. 11, 18) might be one and the same. Moreover, the Bell Fourche Arch is in the approximate position of a northeast-trending zone of thick Morrison Formation rocks (fig. 19), and the structure might have served as a drainage divide during deposition of fluvial deposits in the Lakota Formation. On the isopach map of deposits of the lower part of the Sundance (fig. 11) the broad, northeast-trending zone of thin deposits, the Pine Tree Arch, is in the southern part of the Powder River Basin. The significance of this structure and its effect on Jurassic sedimentation remains unstudied.

The existence of positive relief on the Late Jurassic surface of central Wyoming upon which the Morrison was deposited has been reported by Uhlir (1987b). Uhlir observed that black chert clasts contained in some biosparites in the uppermost Sundance decrease in percentage and grain size away from Laramide uplifts. He also observed that paleocurrent directions obtained from eolianites in the base of the Morrison are toward the north and that these eolianites are commonly concentrated on the northern side of Laramide uplifts. Uhlir believed that this evidence indicates that positive relief existed on the pre-Morrison surface and that these elements were precursors of Laramide structures (also see Brobst, 1961).
Patterns of thick and thin Morrison deposits shown on the isopach map of that formation (fig. 19) reflect the position of intense fluvial erosion associated with the overlying Lakota and Cloverly Formations. The main zone of thin Morrison trends northwest, parallel with the axis of the modern Powder River Basin. If this zone was the result of earliest Cretaceous fluvial erosion, an incipient basin might be indicated.

\section{SUMMARY}

1. During the Early Jurassic, the area of the Powder River Basin was most likely above sea level and subjected to extensive erosion. This erosional event is now represented by the $\mathrm{J}-1$ unconformity, which separates Triassic rocks from Jurassic rocks. Mild tectonism is indicated by a regional discordance between these two systems. Southwest of the Powder River Basin, the eolian Nugget Sandstone was being deposited.

2. Starting in the early Bajocian, the Gypsum Spring sea advanced across parts of the J-1 surface, and the northern and central parts of the Powder River Basin were part of an irregularly shaped, shallow marine sea. During the early and middle Bajocian, deposits of the Gypsum Spring Formation accumulated in this area of the basin, and similar deposits of the Nesson Formation accumulated to the north in the Williston Basin.

3. The Gypsum Spring sea regressed out of the area of the Powder River Basin in the early middle or middle middle Bajocian, and a period of erosion followed that is now represented by the J-2 unconformity. A regional discordance at this level indicates that mild tectonism also occurred.

4. A major marine invasion began in the late middle Bajocian but in the area of this report reached only as far south as the northern part of the Powder River Basin. Deposits of this sea, known as the early Sundance sea, are in the Piper Formation in the Montana part of the basin. Eolian sediments accumulated in the southern part of the basin that were later incorporated into the lower part of the Canyon Springs Sandstone Member of the Sundance Formation.

5. In the late Bathonian, renewed transgression moved the early Sundance sea across the J-2 unconformity into the central and southern parts of the Powder River Basin and beyond. Transgressive deposits of this sea are in the upper part of the Canyon Springs Sandstone and lower part of the Stockade Beaver Shale Members of the Sundance. In the Montana part of the basin, equivalent deposits are in the lower part of the Rierdon Formation.

6. In the latest Bathonian, the early Sundance sea began to regress out of the southern and central Powder River Basin, and, by the middle Callovian, the sea had completely withdrawn. Regressive deposits in the upper part of the Stockade Beaver Shale and Hulett Sandstone 
Members of the Sundance accumulated. The final regressive deposits are in the nonmarine(?) Lak Member of the Sundance. Open-marine strata equivalent to the Stockade Beaver and Hulett in the northern part of the basin are in the middle and upper parts of the Rierdon.

7. In the late middle to early late Callovian, marine waters transgressed into the central and southern Powder River Basin across the Lak and created the Pine Butte sea. In this area of the basin, deposits of this sea are in the Pine Butte Sandstone Member of the Sundance.

8. In the late Callovian, a major regression removed the Pine Butte sea from the region, and a subsequent period of erosion created the J-4 unconformity that separates the lower part of the Sundance from the upper part. In the Montana part of the Powder River Basin the unconformity separates the Rierdon from the overlying Swift Formation. Mild tectonism is indicated by angular discordance at this level.

9. In the early Oxfordian, another major marine invasion moved marine water back into the area of the Powder River Basin, forming the late Sundance sea. Transgressive deposits of this sea are in the lower part of the Redwater Shale Member of the Sundance. In the Montana part of the basin, deposits of the late Sundance sea are in the Swift Formation.

10. Beginning in the late early Oxfordian, the late Sundance sea began regressing out of the area of the Powder River Basin. Deposits representing this regression are in the upper part of the Redwater.

11. By the middle Oxfordian, the late Sundance sea had withdrawn from the southern and central parts of the Powder River Basin; the ensuing erosion event resulted in the J-5 unconformity.

12. Later in the middle Oxfordian, a final marine invasion moved marine water back into the area of the southern and central parts of the Powder River Basin in the form of the Windy Hill sea. Deposits of this event are in the Windy Hill Sandstone Member of the Sundance.

13. At the beginning of the late Oxfordian, a rapid regression removed the Windy Hill sea from the area of the Powder River Basin.

14. Beginning in the Kimmeridgian or possibly earlier, nonmarine deposits, now in the Morrison Formation, prograded from the west over exposed marine deposits. This deposition continued through the Kimmeridgian and possible into the Tithonian.

15. At the close of the Jurassic, deposition of nonmarine rocks continued in the area of the Powder River Basin but under different fluvial conditions and supplied by a different source area. Rocks of Cretaceous age, representing the latter part of this nonmarine period, are in the Cloverly Formation on the western side of the basin and in the Lakota Formation on the eastern side of the basin. An erosion event of undetermined duration might have occurred between these two systems.

\section{SELECTED REFERENCES}

Agard, S.S., 1988, Preliminary geologic map of the Yellowtail Dam Quadrangle, Big Horn County, Montana: U.S. Geological Survey Miscellaneous Field Studies Map MF-2039, scale 1:24,000.

Anderson, F.W., 1973, The Jurassic-Cretaceous transition; the non-marine ostracod faunas, in Casey, R., and Rawson, P.F., eds., The boreal Lower Cretaceous: Liverpool, England, Steel House Press, p. 101-110.

Anderson, K.A., 1978, Early lithification of limestones in the Redwater Shale Member of the Sundance (Jurassic) of southeastern Wyoming: Laramie, University of Wyoming, M.S. thesis, $74 \mathrm{p}$.

Anna, L.O., 1986, Geologic framework of the ground-water system in Jurassic and Cretaceous rocks in the northern Great Plains, in parts of Montana, North Dakota, South Dakota, and Wyoming: U.S. Geological Survey Professional Paper 1402-B, $36 \mathrm{p}$.

Barlow, J.A., Jr., 1950, Geology of the Laramie Creek-Boxelder Creek area, Converse County, Wyoming: Laramie, University of Wyoming, M.A. thesis, $49 \mathrm{p}$.

Bartram, J.G., 1930, Triassic-Jurassic red beds of the Rocky Mountain region: Journal of Geology, v. 38, no. 4, p. 335345.

Bergendahl, M.H., Davies, R.E., and Izett, G.A., 1961, Geology and mineral deposits of the Carlile Quadrangle, Crook County, Wyoming: U.S. Geological Survey Bulletin 1082-J, p. 613-702.

Bergstrom, J.R., 1950, Geology of the east portion of Casper Mountain and vicinity: Laramie, University of Wyoming, M.A. thesis, $55 \mathrm{p}$.

Berryman, R.J., 1942, The geology of the Deer Creek-Little Deer Creek area, Converse County, Wyoming: Laramie, University of Wyoming, M.A. thesis, $51 \mathrm{p}$.

Blakey, R.C., Peterson, F., and Kocurek, G., 1988, Synthesis of late Paleozoic and Mesozoic eolian deposits of the Western Interior of the United States, in Kocurek, G., ed., Late Paleozoic and Mesozoic eolian deposits of the Western Interior of the United States: Sedimentary Geology, v. 56, no. 1-4, p. 3-125.

Bowen, R., 1961, Paleotemperature analysis of Belemnoidea and Jurassic paleoclimatology: Journal of Geology, v. 69, p. $309-320$.

Braddock, W.A., 1963, Geology of the Jewel Cave SW Quadrangle, Custer County, South Dakota: U.S. Geological Survey Bulletin 1063-G, p. 217-268.

Brenner, R.L., 1973, Oxfordian sedimentation in the Western Interior of the U.S.A.: Columbia, University of Missouri, Ph.D. thesis, $189 \mathrm{p}$.

1983, Late Jurassic tectonic setting and paleogeography of western interior, North America, in Reynolds, M.W., and Dolly, E.D., eds., Mesozoic paleogeography of the westcentral United States: Society of Economic Paleontologists and Mineralogists, Rocky Mountain Section, p. 119-132.

Brenner, R.L., and Davies, D.K., 1973, Storm-generated coquinoid sandstone; genesis of high-energy marine sedimentation from the Upper Jurassic of Wyoming and Montana: Geological Society of America Bulletin, v. 84, no. 5, p. $1685-1698$. 
1983, Oxfordian sedimentation in western interior United States: American Association of Petroleum Geologists Bulletin, v. 58, no. 3, p. 407-428.

1974b, Storm-generated coquinoid sandstone; genesis of high-energy marine sedimentation from the Upper Jurassic of Wyoming and Montana; reply: Geological Society of America Bulletin, v. 85, no. 5, p. 838 .

Brenner, R.L., Swift, D.J.P., and Gaynor, G.C., 1985, Reevaluation of coquinoid sandstone depositional model, Upper Jurassic of central Wyoming and south-central Montana: Sedimentology, v. 32, no. 3, p. 363-372.

Brobst, D.A., 1961, Geology of the Dewey Quadrangle, WyomingSouth Dakota: U.S. Geological Survey Bulletin 1063-B, p. $13-60$.

Brobst, D.A., and Epstein, J.B., 1963, Geology of the Fanny Peak Quadrangle, Wyoming-South Dakota: U.S. Geological Survey Bulletin 1063-I, p. 323-377.

Burk, C.A., 1956, Subsurface stratigraphy of the pre-Niobrara formations in the Wind River Basin, in Burk, C.A., chairman, Wyoming stratigraphy, Part I, Subsurface stratigraphy of the pre-Niobrara formations of Wyoming: Wyoming Geological Association, p. 23-33.

Burma, B.H., 1941, The pre-Morrison Jurassic of eastern Wyoming and western South Dakota: Madison, University of Wisconsin, M.A. thesis, 74 p.

Carlson, C.E., 1949, Areal geology and stratigraphy of the Red Fork of the Powder River area, Johnson County, Wyoming: Laramie, University of Wyoming, M.A. thesis, 59 p.

Chisholm, W.A., 1963, The petrology of Upper Jurassic and Lower Cretaceous strata of the western interior, in Cooper, G.G., Cardinal, D.F., Lorenz, H.W., and Lynn, J.R., eds., Northern Powder River Basin: Wyoming Geological Association and Billings Geological Society Joint Field Conference, 1st, Guidebook, p. 71-86.

Cobban, W.A., 1945, Marine Jurassic formations of Sweetgrass arch, Montana: American Association of Petroleum Geologists Bulletin, v. 29, no. 9, p. 1262-1303.

Crickmay, C.H., 1936, Study in the Jurassic of Wyoming: Geological Society of America Bulletin, v. 47, p. 541-564.

Cross, C.W., 1894, Description of the Pikes Peak Sheet (Colorado): U.S. Geological Survey Geological Atlas Folio 7, 5 p.

Cuppels, N.P., 1963, Geology of the Clifton Quadrangle, Wyoming and South Dakota: U.S. Geological Survey Bulletin 1063-H, p. 271-321.

Curry, W.H., and Hegna, E.T., 1970, Stratigraphic oil accumulations in the lower Sundance Canyon Springs Sandstones of Wyoming, in Enyert, R.L., ed., Symposium on Wyoming sandstones: Wyoming Geological Association Field Conference, 22nd, Guidebook, p. 51-74.

Darton, N.H., 1899, Jurassic formations of the Black Hills of South Dakota: Geological Society of America Bulletin, v. 10, p. 383-396.

1901a, Comparison of the stratigraphy of the Black Hills with that of the front range of the Rocky Mountains: American Journal of Science, News Service, v. 13, no. 318, p. 188.

$1901 \mathrm{~b}$, Geology and water resources of the southern half of the Black Hills and adjoining regions in South Dakota and Wyoming: U.S. Geological Survey Twenty-first Annual Report, Part 4, p. 489-599.
1904, Comparison of the stratigraphy of the Black Hills, Bighorn Mountains and Rocky Mountain Front Range: Geological Society of America Bulletin, v. 15, p. 379-448. 1909 , Geology and water resources of the northern portion of the Black Hills and adjoining regions in Wyoming and South Dakota: U.S. Geological Survey Professional Paper $65,105 \mathrm{p}$.

Darton, N.H., and Paige, S., 1925, Central Black Hills folio, South Dakota: U.S. Geological Survey Geologic Atlas Folio 219, $34 \mathrm{p}$.

Davis, R.E., and Izett, G.A., 1962, Geology and uranium deposits of the Strawberry Hill Quadrangle, Crook County, Wyoming: U.S. Geological Survey Bulletin 1127, 87 p.

Denson, N.M., and Botinelly, T., 1949, Geology of the Hartville uplift, eastern Wyoming: U.S. Geological Survey Oil and Gas Investigations Preliminary Map 102, scale 1:48,000.

Douglass, D.N., 1984, Stratigraphy and paleomagnetics of the Morrison and Cloverly Formations, Big Horn Basin, Wyoming: Hanover, New Hampshire, Dartmouth College, M.A. thesis, $126 \mathrm{p}$.

Downey, J.S., 1986, Geohydrology of bedrock aquifers in the northern Great Plains in parts of Montana, North Dakota, South Dakota, and Wyoming: U.S. Geological Survey Professional Paper 1402-E, 87 p.

Downs, G.R., 1949, Mesozoic rocks of the northern Powder River Basin, Wyoming: Wyoming Geological Association Annual Field Conference, Powder River Basin, 4th, Guidebook, p. $46-50$.

Dresser, H.W., 1959, A field study of the Jurassic "lower Sundance" beds in southeastern Wyoming: Laramie, University of Wyoming, Ph.D. thesis, 667 p.

Drwenski, V.R., 1952, Geology of the Boxelder-Mormon Canyon area Converse County, Wyoming: Laramie, University of Wyoming, M.A. thesis, $67 \mathrm{p}$.

Eldridge, G.H., 1896, Mesozoic geology, in Geology of the Denver basin in Colorado: U.S. Geological Survey Monograph 27, p. 51-151.

Epstein, J.B., 1958, Geology of part of the Fanny Peak Quadrangle, Wyoming-South Dakota: Laramie, University of Wyoming, M.A. thesis, $90 \mathrm{p}$.

Faulkner, G.L., 1950, Geology of the Bessemer Mountain-Oil Mountain area, Natrona County, Wyoming: Laramie, University of Wyoming, M.A. thesis, $63 \mathrm{p}$.

1956, Subsurface stratigraphy of the pre-Niobrara formations along the western margin of the Powder River Basin, Wyoming, in Burk, C.A., chairman, Wyoming stratigraphy, Part I, Subsurface stratigraphy of the preNiobrara formations of Wyoming: Wyoming Geological Association, p. 35-42.

Fenner, P., 1961, Stratigraphy and petrology of the lower Sundance formation (Upper Jurassic) on the flanks of the Bighorn Mountains, Wyoming: Urbana, University of Illinois, M.S. thesis, $38 \mathrm{p}$.

Fox, J.E., and Dandavati, K., 1982, Unkpapa Sandstone, Inyan Kara Group and Sundance Formation, in Ahlbrandt, T.S., Swinehart, J.B., Fox, J.E., and Dandavati, K., leaders, Past and present eolian sediments: Society of Economic Paleontologists, Rocky Mountain Section, Fall Field Trip, 1982, p. 1-29. 
Gillum, J.P., 1956, Stratigraphy and structure of the Alkali Creek-Willow Creek area, Natrona County, Wyoming: Laramie, University of Wyoming, M.A. thesis, 43 p.

Gott, G.B., Wolcott, D.E., and Bowles, C.G., 1974, Stratigraphy of the Inyan Kara Group and localization of uranium deposits, southern Black Hills, South Dakota and Wyoming: U.S. Geological Survey Professional Paper 763, $57 \mathrm{p}$.

Graham, G.E., 1950, Petrographic study of the heavy minerals of certain sandstones of the Sundance Formation of western South Dakota and Wyoming: Lincoln, University of Nebraska, M.S. thesis, $56 \mathrm{p}$.

Greene, J.F., 1970, Stratigraphy and sedimentary tectonics of the Gypsum Springs Formation, Middle Jurassic, Fremont County, Wyoming: Ann Arbor, University of Michigan, M.S. thesis, $37 \mathrm{p}$.

Griffith, C.E., 1972, Palynostratigraphy of the Sundance Formation (Jurassic) of the Black Hills area, South Dakota and Wyoming: Commerce, East Texas State University, M.S. thesis, $108 \mathrm{p}$.

Habicht, J.K.A., 1979, Paleoclimate, paleomagnetism, and continental drift: American Association of Petroleum Geologists Studies in Geology 9, 31 p.

Hallam, A., 1975, Jurassic environments: Cambridge, England, Cambridge University Press, 269 p.

1988, A reevaluation of Jurassic eustasy in the light of new data and the revised Exxon curve, in Wilgus, C.K., Hastings, B.S., Posamentier, H., Van Wagoner, J., Ross, C.A., and Kendall, C.G., eds, Sea-level changes-An integrated approach: Society of Economic Paleontologists and Mineralogists Special Publication 42, p. 261-273.

Haq, B.U., Hardenbol, J., and Vail, P.R., 1987, Chronology of fluctuating sea levels since the Triassic: Science, v. 235 , p. 1156-1167.

Hinrichs, E.N., 1979, Preliminary geologic map of the Beaver Creek Hills Quadrangle, Sheridan County, Wyoming: U.S. Geological Survey Miscellaneous Field Studies Map MF-1084, scale 1:24,000.

Hose, R.K., 1955, Geology of the Crazy Woman Creek area, Johnson County, Wyoming: U.S. Geological Survey Bulletin 1027-B, 118 p.

Hubbell, R.G., 1954, Stratigraphy of the Jelm, Nugget and Sundance Formations of northern Carbon County, Wyoming: Laramie, University of Wyoming, M.A. thesis, $131 \mathrm{p}$.

Imlay, R.W., 1945, Occurrence of Middle Jurassic rocks in western interior of the United States: American Association of Petroleum Geologist Bulletin, v. 29, no. 7, p. 1019-1027. 1947, Marine Jurassic of the Black Hills, South Dakota: American Association of Petroleum Geologists Bulletin v. 31 , no. 2 , p. $227-273$.

1948, Characteristic marine Jurassic fossils from the western interior of the United States: U.S. Geological Survey Professional Paper 214-B, 33 p.

1950 , Paleoecology of Jurassic seas in the western interior of the United States, in Ladd, H.S., chairman, Report of the committee on a treatise on marine ecology and paleoecology: National Research Council, p. 72-104.

1952a, Correlation of the Jurassic formations of North America, exclusive of Canada: Geological Society of America Bulletin, v. 63, no. 9, p. 953-992.
$1952 \mathrm{~b}$, Summary of Jurassic history in the western interior of the United States, in Sonnenberg, F.P., ed., Black Hills-Williston Basin: Billings Geological Society Annual Field Conference, 3rd, Guidebook, p. 79-85.

1954, Marine Jurassic formations in the Pryor Mountains and northern Bighorn Mountains, Montana, in Richards, P.W., ed., Pryor Mountains-northern Bighorn Basin, Montana: Billings Geological Society Annual Field Conference, 5th, Guidebook, p. 54-64.

1956, Marine Jurassic exposures in Bighorn Basin, Pryor Mountains, and northern Bighorn Mountains, Wyoming and Montana: American Association of Petroleum Geologists Bulletin, v. 40, no. 4, p. 562-599.

1957, Paleoecology of the Jurassic seas in the western interior of the United States, in Ladd, H.S., ed., Treatise on marine ecology and paleoecology, v. 2, Paleoecology: Geological Society of America Memoir 67, p. 469-504.

1965, Jurassic marine faunal differentiation in North America: Journal of Paleontology, v. 39, no. 5, p. 10231038.

1980, Jurassic paleobiogeography of the conterminous United States in its continental setting: U.S. Geological Survey Professional Paper 1062, 134 p.

Jenkins, C.E., 1950, Geology of the Bates Creek-Corral Creek area, Natrona County, Wyoming: Laramie, University of Wyoming, M.A. thesis, $80 \mathrm{p}$.

Jenney, W.P., 1899, Field observations in the Hay Creek coal field, Wyoming: U.S. Geological Survey 19th Annual Report, Part 2, p. 568-593.

Kocurek, G., and Dott, R.H., 1983, Jurassic paleogeography and paleoclimate of the central and southern Rocky Mountains region, in Reynolds, M.W., and Dolly, E.D., eds., Mesozoic paleogeography of the west-central United States: Society of Economic Paleontologists and Mineralogists, Rocky Mountain Section, p. 101-116.

Kowallis, B.J., Heaton, J.S., and Bringhurst, K., 1986, Fissiontrack dating of volcanically derived sedimentary rocks: Geology, v. 14, no. 1, p. 19-22.

Kvale, E.P., and Vondra, C.F., 1985, Upper Jurassic-Lower Cretaceous transitional marine and fluvial sediments in the Bighorn Basin, in Flores, R.M., and Harvey, M.D., eds., Field guidebook to modern and ancient fluvial systems in the United States: Society of Economic Paleontologists and Mineralogists, Third International Fluvial Sedimentology Conference, Fort Collins, Colorado, p. 33-44.

Love, J.D., 1939, Geology along the southern margin of the Absaroka Range, Wyoming: Geological Society of America Special Paper 20, 134 p.

1958, Stratigraphy and fossils of marine Jurassic rocks along the southern margin of the Powder River Basin, Wyoming: Wyoming Geological Association Annual Field Conference, Powder River Basin, 13th, Guidebook, p. 64-70.

Love, J.D., and Christiansen, A.C., 1985, Geologic map of Wyoming: U.S. Geological Survey, scale 1:500,000.

Love, J.D., Denson, N.M., and Botinelly, T., 1949, Geology of the Glendo area, Wyoming: U.S. Geological Survey Oil and Gas Investigations Preliminary Map 92, scale 1:48,000. 
Love, J.D., Tourtelot, R.M., Johnson, C.O., Sharkey, H.H.R., Thompson, R.M., and Zapp, A.D., 1945, Stratigraphic sections and thickness maps of Jurassic rocks in central Wyoming: U.S. Geological Survey Oil and Gas Investigations Preliminary Chart 14.

MacClintock, C., 1957, Upper part of Morrison and Cloverly Formations, southeastern Big Horn Mountains, Wyoming: Laramie, University of Wyoming, M.A. thesis, $142 \mathrm{p}$.

Mapel, W.J., 1959, Geology and coal resources of the BuffaloLake DeSmet area Johnson and Sheridan Counties, Wyoming: U.S. Geological Survey Bulletin 1078, 148 p.

Mapel, W.J., and Bergendahl, M.H., 1956, Gypsum Springs Formation, northwestern Black Hills, Wyoming and South Dakota: American Association of Petroleum Geologists Bulletin, v. 40, no. 1, p. 84-93.

Mapel, W.J., Chisholm, W.A., and Bergenback, R.E., 1964, Nonopaque heavy mineral in sandstones of Jurassic and Cretaceous age in the Black Hills, Wyoming and South Dakota: U.S. Geological Survey Bulletin 1161-C, 59 p.

Mapel, W.J., and Gott, G.B., 1959, Diagrammatic restored section of the Inyan Kara Group, Morrison Formation, and Unkpapa Sandstone on the west side of the Black Hills, Wyoming and South Dakota: U.S. Geological Survey Mineral Investigation Map MF-218.

Mapel, W.J., and Pillmore, C.L., 1963a, Geology of the Newcastle area, Weston County, Wyoming: U.S. Geological Survey Bulletin 1141-N, 85 p.

1963b, Geology of the Inyan Kara Mountain Quadrangle, Crook and Weston Counties, Wyoming: U.S. Geological Survey Bulletin 1121-M, $56 \mathrm{p}$.

1964, Geology of the Upton Quadrangle, Crook and Weston Counties, Wyoming: U.S. Geological Survey Bulletin 1181-J, $54 \mathrm{p}$.

Marrs, R.W., and Raines, G.L., 1984, Tectonic framework of Powder River Basin, Wyoming and Montana, interpreted from Landsat imagery: American Association of Petroleum Geologists Bulletin, v. 68, no. 11, p. 1718-1731.

Maughan, E.K., 1983, Tectonic setting of the Rocky Mountain region during the late Paleozoic and the early Mesozoic, in Proceedings of the Symposium on the Genesis of Rocky Mountain Ore Deposits-Changes with Time and Tectonics: Denver Regional Exploration Geologists Society, p. 39-50.

McCanne, R.W., 1949, Lance Creek, East Lance Creek, and Little Buck Creek oil fields, Niobrara County, Wyoming: Wyoming Geological Association Annual Field Conference, Powder River Basin, 4th, Guidebook, p. 85-87.

McKee, E.D., Oriel, S.S., Swanson, V.E., MacLachlan, M.E., MacLachlan, J.C., Ketner, K.B., Goldsmith, J.W., Bell, R.Y., and Jameson, D.J., 1956, Paleotectonic maps of the Jurassic System: U.S. Geological Survey Miscellaneous Geological Investigations Map I-175, scale 1:5,000,000.

Mirsky, A., 1960, Stratigraphy of the nonmarine Upper Jurassic and Lower Cretaceous rocks, southern Big Horn Mountains, Wyoming: Ann Arbor, University of Michigan, Ph.D. thesis, $182 \mathrm{p}$.

1961, Mechanical analysis and heavy minerals, Morrison and Cloverly Formations, southern Big Horn Mountains, Wyoming: Journal of Sedimentary Petrology, v. 31, no. 4, p. 571-585. 1962a, Stratigraphy of non-marine Upper Jurassic and Lower Cretaceous rocks, southern Bighorn Mountains, Wyoming: American Association of Petroleum Geologists Bulletin, v. 46, no. 9, p. 1653-1680.

1962b, Stratigraphic sections of Upper Jurassic and Lower Cretaceous rocks in the southern Bighorn Mountains, Wyoming: Geological Survey of Wyoming Report of Investigations $8,33 \mathrm{p}$.

Moberly, R., Jr., 1960, Morrison, Cloverly, and Sykes Mountain Formations, northern Bighorn Basin, Wyoming and Montana: Geological Society of America Bulletin, v. 71, no. 8, p. 1137-1176.

Neeley, J., 1937, Stratigraphy of the Sundance Formation and related Jurassic rocks in Wyoming and their petroleum aspects: American Association of Petroleum Geologists Bulletin, v. 21, no. 6, p. 715-770.

Nelson, C.M., 1963, Gypsum Spring and "lower" Sundance Formations, eastern Big Horn Mountains, Wyoming and Montana: East Lansing, Michigan State University, M.S. thesis, $127 \mathrm{p}$.

Nordquist, J.W., 1955, Pre-Rierdon Jurassic stratigraphy in northern Montana and Williston Basin, in Lewis, P.J., ed., Sweetgrass arch-Disturbed belt, Montana: Billings Geological Society Annual Field Conference, 6th, Guidebook, p. 96-106.

Ostrom, J.H., 1970, Stratigraphy and paleontology of the Cloverly Formation (Lower Cretaceous) of the Bighorn Basin area, Wyoming and Montana: Peabody Museum of Natural History, Yale University Bulletin 35, 234 p.

Owen, D.E., Turner-Peterson, C.E., and Fishman, N.S., 1989, $\mathrm{X}$-ray diffraction studies of the $<0.5-\mu \mathrm{m}$ fraction from the Brushy Basin Member of the Upper Jurassic Morrison Formation, Colorado Plateau: U.S. Geological Survey Bulletin 1808-G, $25 \mathrm{p}$.

Parrish, J.T., and Peterson, F., 1988, Wind directions predicted from global circulation models and wind directions determined from eolian sandstones of the western United States-A comparison, in Kocurek, G, ed., Late Paleozoic and Mesozoic eolian deposits of the western interior of the United States: Sedimentary Geology, v. 56, no. 1-4, p. 261-282.

Peterson, F., 1988, Pennsylvanian to Jurassic eolian transportation systems in the western United States, in Kocurek, G., ed., Late Paleozoic and Mesozoic eolian deposits of the western interior of the United States: Sedimentary Geology, v. 56, no. 1-4, p. 207-251.

Peterson, J.A., 1952, Stratigraphy and micropaleontology of the Sundance Group, eastern Wyoming: Minneapolis, University of Minnesota, Ph.D. thesis, $148 \mathrm{p}$.

1954a, Jurassic ostracoda from the "lower" Sundance and Rierdon Formations, western interior United States: Journal of Paleontology, v. 28, no. 2, p. 153-176.

1954b, Marine Upper Jurassic, eastern Wyoming: American Association of Petroleum Geologists Bulletin, v. 38, no. 4, p. 463-507.

1955, Marine Jurassic rocks, northern and eastern Uinta Mountains and adjacent areas: Wyoming Geological Association Annual Field Conference, 10th, Guidebook, p. 75-79. 
1957a, Marine Jurassic of the northern Rocky Mountains and Williston Basin: American Association of Petroleum Geologists Bulletin, v. 41, no. 3, p. 399-440.

1957b, Gypsum Springs and Sundance Formations, central Wyoming: Wyoming Geological Association Annual Field Conference 12th, Southwestern Wind River Basin, Guidebook, p. 47-54.

1957c, The Swift-Rierdon boundary problem in central Montana and the Williston basin, in Graves, R.W., Jr., ed., Crazy Mountain basin: Billings Geological Society Annual Field Conference, 8th, Guidebook, p. 76-79.

1958, Paleotectonic control of marine Jurassic sedimentation in the Powder River Basin: Wyoming Geological Association Annual Field Conference 13th, Powder River Basin Guidebook, p. 56-63.

1972, Jurassic System, in Mallory, W.W., ed., Geological atlas of the Rocky Mountain region: Rocky Mountain Association of Geologists, p. 177-189.

1985, Regional stratigraphy and general petroleum geology of Montana and adjacent areas, in Tonnsen, T.T., ed., Montana Oil and Gas Fields Symposium, 1985: Billings Geological Society, p. 5-45.

1988, Phanerozoic stratigraphy of the northern Rocky Mountains region, in Sloss, L.L., ed., The geology of North America, v. D-2, Sedimentary cover-North American craton, U.S.: Geological Society of America, p. 83-107.

Peterson, J.A., and Smith, D.L., 1986, Rocky Mountain paleogeography through geologic time, in Peterson, J.A., ed., Paleotectonics and sedimentation in the Rocky Mountain region, United States: American Association of Petroleum Geologists Memoir 41, p. 3-19.

Pillmore, C.L., and Mapel, W.J., 1963, Geology of the Nefsy Divide Quadrangle, Crook County, Wyoming: U.S. Geological Survey Bulletin 1121-E, 52 p.

Pipiringos, G.N., 1953, Correlation of marine Jurassic and related rocks in the Laramie Basin, Wyoming: Wyoming Geological Association Annual Field Conference 8th, Laramie Basin, Wyoming, and North Park, Colorado, Guidebook, p. 34-39.

1957, Stratigraphy of the Sundance, Nugget, and Jelm Formations of the Laramie Basin, Wyoming: Geological Survey of Wyoming Bulletin 47, 63 p.

1968, Correlation and nomenclature of some TriassicJurassic rocks in south-central Wyoming: U.S. Geological Survey Professional Paper 594-D, 29 p.

Pipiringos, G.N., Hail, W.J., Jr., and Izett, G.A., 1969, The Chinle (Upper Triassic) and Sundance (Upper Jurassic) Formations in north-central Colorado: U.S. Geological Survey Bulletin $1274-\mathrm{N}, 35 \mathrm{p}$.

Pipiringos, G.N., and O'Sullivan, R.B., 1976, Stratigraphic sections of some Triassic and Jurassic rocks from Douglas, Wyoming, to Boulder, Colorado: U.S. Geological Survey Oil and Gas Investigations Chart OC-69.

1978, Principal unconformities in Triassic and Jurassic rocks, western interior United States-A preliminary survey: U.S. Geological Survey Professional Paper 1035-A, $29 \mathrm{p}$.

Post, E.V., 1967, Geology of the Cascade Springs Quadrangle, Fall River County, South Dakota: U.S. Geological Survey Bulletin 1063-L, p. 443-504.
Ramsey, R.D., 1955, Geology of the Big Goose Canyon area, Sheridan County, Wyoming: Laramie, University of Wyoming, M.A. thesis, $111 \mathrm{p}$.

Rautman, C.A., 1975, Sedimentology of the "Lower" Sundance Formation (Upper Jurassic), Wyoming region: Wyoming Geological Association, Earth Science Bulletin, v. 8, no. 4, p. 1-16.

1976a, Depositional environments of the "Lower Sundance" Formation (Upper Jurassic) of the eastern Wyoming region: Madison, University of Wisconsin, Ph.D. thesis, 9 p.

1976b, Late Jurassic barrier island complex in "Lower" Sundance Formation of Black Hills [abs.]: American Association of Petroleum Geologists Bulletin, v. 60 , no. 4, p. 711 .

1978, Sedimentation of Late Jurassic Barrier-island complex-Lower Sundance Formation of Black Hills: American Association of Petroleum Geologists Bulletin, v. 62 , no. 11 , p. $2275-2289$.

Rautman, C.A., and Dott, R.H., 1977, Dish structures formed by fluid escape in Jurassic shallow marine sandstones: Journal of Sedimentary Petrology, v. 47, no. 1, p. 101-106.

Richards, P.W., 1955, Geology of the Bighorn Canyon-Hardin area, Montana and Wyoming: U.S. Geological Survey Bulletin 1026, 93 p.

Richardson, A.L., 1950, Geology of the Mayoworth region, Johnson County, Wyoming: Laramie, University of Wyoming, M.A. thesis, $62 \mathrm{p}$.

Robinson, C.S., Mapel, W.J., and Bergendahl, M.H., 1964, Stratigraphy and structure of the northern and west flanks of the Black Hills uplift, Wyoming, Montana, and South Dakota: U.S. Geological Survey Professional Paper 404, $134 \mathrm{p}$.

Roy, D.H., 1960, Petrography of the upper Sundance Formation on the flanks of the Big Horn Mountains, Wyoming: Urbana, University of Illinois, M.S. thesis, 40 p.

Sacrison, W.R., 1958, A study of the Jurassic Unkapapa Sandstone of the Black Hills region, western South Dakota and eastern Wyoming: Laramie, University of Wyoming, M.A. thesis, $78 \mathrm{p}$.

Sandberg, D.T., 1959, Structure contour map on top of the middle member of the Piper Formation of Middle Jurassic age in the Williston basin and adjacent areas in Montana, North Dakota, and South Dakota: U.S. Geological Survey Oil and Gas Investigations Map OM-179, scale 1:760,320.

Schmitt, G.T., 1953, Regional stratigraphic analysis of Middle and Upper marine Jurassic in the northern Rocky MountainsGreat Plains: American Association of Petroleum Geologists Bulletin, v. 37, no. 2, p. 355-393.

Schwarberg, T.M., 1959, The geology of Muddy Mountain southeast Natrona County, Wyoming: Laramie, University of Wyoming, M.A. thesis, $103 \mathrm{p}$.

Sears, W.A., 1949, Geology of the Deer Creek-Smith Creek area, Converse and Natrona Counties, Wyoming: Laramie, University of Wyoming, M.A. thesis, $56 \mathrm{p}$.

Shurr, G.W., Anna, L.O., and Peterson, J.A., 1989, Zuni sequence in Williston Basin-Evidence for Mesozoic paleotectonism: American Association of Petroleum Geologists Bulletin, v. 73 , no. 1 , p. $68-87$. 
Sims, F.C., 1948, Geology of the west end of the Laramie Range, Natrona County, Wyoming: Laramie, University of Wyoming, M.A. thesis, $52 \mathrm{p}$.

Slack, P.B., 1981, Paleotectonics and hydrocarbon accumulation, Powder River Basin, Wyoming: American Association of Petroleum Geologists Bulletin, v. 65, no. 4, p. 730-743.

Sloss, L.L., 1963, Sequences in the cratonic interior of North America: Geological Society of America Bulletin, v. 74, p. 93-113.

Smith, A.G., and Briden, J.C., 1977, Mesozoic and Cenozoic paleocontinental maps: Cambridge, England, Cambridge Earth Science Series, Cambridge University Press, 63 p.

Sohn, I.G., 1958, Middle Mesozoic non-marine ostracodes of the Black Hills: Wyoming Geological Association Annual Field Conference, 13th, Powder River Basin, p. 120-126.

Sohn, I.G., and Peck, R.E., 1963, Theriosynoecum wyomingensis (Branson, 1935), a possible guide ostracode to the Salt Wash Member of the Morrison Formation: U.S. Geological Survey Bulletin 1161-A, 10 p.

Specht, R.W., and Brenner, R.L., 1979, Storm-wave genesis of bioclastic carbonate in Upper Jurassic epicontinental mudstones, east-central Wyoming: Journal of Sedimentary Petrology, v. 49, no. 4, p. 1307-1322.

Spelman, A.R., 1959, Geology of the area between Bed Tick Creek and the west fork of LaBonte Creek, Converse County, Wyoming: Laramie, University of Wyoming, M.A. thesis, $81 \mathrm{p}$.

Stokes, W.L., 1944, Morrison Formation and related deposits in and adjacent to the Colorado Plateau: Geological Society of America Bulletin, v. 55, p. 951-992.

1950, Pediment concept applied to Shinarump and similar conglomerates: Geological Society of America Bulletin, v. 61, p. 91-98.

Stone, R., and Vondra, C.F., 1972, Sediment dispersal pattern of oolitic calcarenite in the Sundance (Jurassic), Wyoming: Journal of Sedimentary Petrology, v. 42, no. 1, p. 227-229.

Szigeti, G.J., and Fox, J.E., 1981, Unkpapa Sandstone (Jurassic), Black Hills, South Dakota; an eolian facies of the Morrison Formation: Society of Economic Paleontologists and Mineralogists Special Publication 31, p. 331-349.

Tank, R.W., 1955, The Morrison Formation of the Black Hills area, South Dakota and Wyoming: Madison, University of Wisconsin, M.S. thesis, $46 \mathrm{p}$.

1956, Clay mineralogy of Morrison Formation, Black Hills area, Wyoming and South Dakota: American Association of Petroleum Geologists Bulletin, v. 40, no. 5, p. 871-878.

Thorman, C.H., Ketner, K.B., and Peterson, F., 1990, The Elko orogeny-Late Jurassic orogenesis in the Cordilleran miogeosyncline: Geological Society of America Abstracts with Programs, v. 22, no. 3, p. 88.

Tourtelot, H.A., 1953, Geology of the Badwater area, central Wyoming: U.S. Geological Survey Oil and Gas Investigations Map OM-124, scale 1:48,000.

Uhlir, D.M., 1986, Eolian sandstone unit of Morrison Formation, central Wyoming [abs.]: American Association of Petroleum Geologists Bulletin, v. 70, no. 8, p. 1059.

1987a, Sedimentology of the Sundance Formation, northern Wyoming: Ames, Iowa State University, Ph.D. thesis, $111 \mathrm{p}$. 1987b, Subtle tectonics in the Late Jurassic Wyoming Foreland; distribution of Sundance chert and Morrison eolianites: Geological Society of America Abstracts with Programs, v. 19, no. 5, p. 339.

Uhlir, D.M., Akers, A., and Vondra, C.F., 1988, Tidal inlet sequence, Sundance Formation (Upper Jurassic), northcentral Wyoming: Sedimentation, v. 35, no. 5, p. 739-752.

Uhlir, D.M., and Vondra, C.F., 1984, Tidal influence in Late Jurassic shallow sea; evidence from the Sundance Formation, Wyoming: Geological Society of America Abstracts with Programs, v. 16, no. 6, p. 680.

Uhlir, D.M., Vondra, C.F., and Akers, A., 1986, Mesotidal barrier complex, Sundance Formation, north-central Wyoming [abs.]: American Association of Petroleum Geologists Bulletin, v. 70, no. 8, p. 1059 .

Unash, C., 1925, The stratigraphy and fauna of the Sundance Formation of the northern Black Hills: Iowa City, University of Iowa, M.S. thesis, $75 \mathrm{p}$.

U.S. Geological Survey, 1965, Geological research 1965: U.S. Geological Survey Professional Paper 525-A, p. 88.

Waage, K.M., 1959, Stratigraphy of the Inyan Kara Group in the Black Hills: U.S. Geological Survey Bulletin 1081-B, 90 p.

Weed, D.D., and Vondra, C.F., 1987, Implications of an eolian sandstone unit of basal Morrison Formation, central Wyoming [abs.]: American Association of Petroleum Geologists Bulletin, v. 71 , no. 5, p. 626

Weiss, M.P., and Wenden, H.E., 1965, Calcite spherulites from the Morrison Formation, Wyoming: Journal of Sedimentary Petrology, v. 35 , no. 4, p. 985-988.

Wills, J.G., 1955, Geology of the Pine Mountain area, Natrona County, Wyoming: Laramie, University of Wyoming, M.A. thesis, $65 \mathrm{p}$.

Winslow, N.S., and Heller, P.L., 1987, Evaluation of unconformities in Upper Jurassic and Lower Cretaceous nonmarine deposits, Bighorn Basin, Wyoming and Montana, U.S.A.: Sedimentary Geology, v. 53, p. 181-202.

Wolcott, D.E., 1967, Geology of the Hot Springs Quadrangle, Fall River and Custer Counties, South Dakota: U.S. Geological Survey Bulletin 1063-K, p. 427-442.

Woodward, T.C., 1957, Geology of Deadman Butte area, Natrona County, Wyoming: American Association of Petroleum Geologists Bulletin, v. 41, no. 2, p. 212-262.

Wright, R.P., 1971, The marine Jurassic of Wyoming and South Dakota; its paleoenvironments and paleobiogeography: Ann Arbor, University of Michigan, Ph.D. thesis, 167 p.

1973, Marine Jurassic of Wyoming and South Dakota-Its paleoenvironments and paleobiogeography: University of Michigan Museum of Paleontology, Papers on Paleontology, no. 2,49 p.

1974a, Jurassic bivalves from Wyoming and South Dakota-A study of feeding relationships: Journal of Paleontology, v. 48, p. 425-433.

1974b, Storm-generated coquinoid sandstone; genesis of high-energy marine sediments from the Upper Jurassic of Wyoming and Montana; discussion: Geological Society of America Bulletin, v. 85, p. 837.

Yen, T.C., 1952, Molluscan fauna of the Morrison Formation: U.S. Geological Survey Professional Paper 233-B, p. 21-51. 
Yen, Teng-Chien, 1952, Molluscan fauna of the Morrison Formation: U.S. Geological Survey Professional Paper 233-B, $51 \mathrm{p}$.

Zakis, W.N., 1950, Geology of the east flank of the Bighorn Mountains near Dayton, Sheridan County, Wyoming: Laramie, Wyoming, University of Wyoming M.A. thesis, $126 \mathrm{p}$.
Zeiner, T.C., 1974, Upper Sundance-lower Morrison sedimentology, Wyoming, and its stratigraphic implications: Columbia, University of Missouri, M.S. thesis, 92 p.

Zeiner, T.C., and Davies, D.K., 1974, Upper Sundance-lower Morrison sedimentology, Wyoming, and its stratigraphic implications: Geological Society of America Abstracts with Programs, v. 5, no. 2, p. 133. 


\section{SELECTED SERIES OF U.S. GEOLOGICAL SURVEY PUBLICATIONS}

\section{Periodicals}

Earthquakes \& Volcanoes (issued bimonthly).

Preliminary Determination of Epicenters (issued monthly).

\section{Technical Books and Reports}

Professional Papers are mainly comprehensive scientific reports of wide and lasting interest and importance to professional scientists and engineers. Included are reports on the results of resource studies and of topographic, hydrologic, and geologic investigations. They also include collections of related papers addressing different aspects of a single scientific topic.

Bulletins contain significant data and interpretations that are of lasting scientific interest but are generally more limited in scope or geographic coverage than Professional Papers. They include the results of resource studies and of geologic and topographic investigations; as well as collections of short papers related to a specific topic.

Water-Supply Papers are comprehensive reports that present significant interpretive results of hydrologic investigations of wide interest to professional geologists, hydrologists, and engineers. The series covers investigations in all phases of hydrology, including hydrology, availability of water, quality of water, and use of water.

Circulars present administrative information or important scientific information of wide popular interest in a format designed for distribution at no cost to the public. Information is usually of short-term interest.

Water-Resources Investigations Reports are papers of an interpretive nature made available to the public outside the formal USGS publications series. Copies are reproduced on request unlike formal USGS publications, and they are also available for public inspection at depositories indicated in USGS catalogs.

Open-File Reports include unpublished manuscript reports, maps, and other material that are made available for public consultation at depositories. They are a nonpermanent form of publication that maybe cited in other publications as sources of information.

\section{Maps}

Geologic Quadrangle Maps are multicolor geologic maps on topographic bases in $71 / 2$ - or 15 -minute quadrangle formats (scales mainly $1: 24,000$ or $1: 62,500$ ) showing bedrock, surficial, or engineering geology. Maps generally include brief texts; some maps include structure and columnar sections only.

Geophysical Investigations Maps are on topographic or planimetric bases at various scales, they show results of surveys using geophysical techniques, such as gravity, magnetic, seismic, or radioactivity, which reflect subsurface structures that are of economic or geologic significance. Many maps include correlations with the geology.

Miscellaneous Investigations Series Maps are on planimetric or topographic bases of regular and irregular areas at various scales; they present a wide variety of format and subject matter. The series also includes 7 1/2-minute quadrangle photogeologic maps on planimetric bases which show geology as interpreted from aerial photographs. The series also includes maps of Mars and the Moon.
Coal Investigations Maps are geologic maps on topographic or planimetric bases at various scales showing bedrock or surficial geology, stratigraphy, and structural relations in certain coal-resource areas.

Oil and Gas Investigations Charts show stratigraphic information for certain oil and gas fields and other areas having petroleum potential.

Miscellaneous Field Studies Maps are multicolor or black-andwhite maps on topographic or planimetric bases on quadrangle or irregular areas at various scales. Pre-1971 maps show bedrock geology in relation to specific mining or mineral-deposit problems; post-1971 maps are primarily black-and-white maps on various subjects such as environmental studies or wilderness mineral investigations.

Hydrologic Investigations Atlases are multicolored or black-andwhite maps on topographic or planimetric bases presenting a wide range of geohydrologic data of both regular and irregular areas; the principal scale is 1:24,000, and regional studies are at 1:250,000 scale or smaller.

\section{Catalogs}

Permanent catalogs, as well as some others, giving comprehensive listings of U.S. Geological Survey publications are available under the conditions indicated below from the U.S. Geological Survey, Books and Open-File Reports Sales, Box 25425, Denver, CO 80225. (See latest Price and Availability List.)

"Publications of the Geological Survey, 1879-1961" may be purchased by mail and over the counter in paperback book form and as a set microfiche.

"Publications of the Geological Survey, 1962-1970" may be purchased by mail and over the counter in paperback book form and as a set of microfiche.

"Publications of the U.S. Geological Survey, 1971-1981" may be purchased by mail and over the counter in paperback book form (two volumes, publications listing and index) and as a set of microfiche.

Supplements for 1982,1983,1984, 1985, 1986, and for subsequent years since the last permanent catalog may be purchased by mail and over the counter in paperback book form.

State catalogs, "List of U.S. Geological Survey Geologic and Water-Supply Reports and Maps For (State)," may be purchased by mail and over the counter in paperback booklet form only.

"Price and Availability List of U.S. Geological Survey Publica. tions," issued annually, is available free of charge in paperback booklet form only.

Selected copies of a monthly catalog "New Publications of the U.S. Geological Survey" is available free of charge by mail or may be obtained over the counter in paperback booklet form only. Those wishing a free subscription to the monthly catalog "New Publications of the U.S. Geological Survey" should write to the U.S. Geological Survey, $582 \mathrm{Na-}$ tional Center, Reston, VA 22092.

Note.-Prices of Government publications listed in older catalogs, announcements, and publications may be incorrect. Therefore, the prices charged may differ from the prices in catalogs, announcements, and publications. 


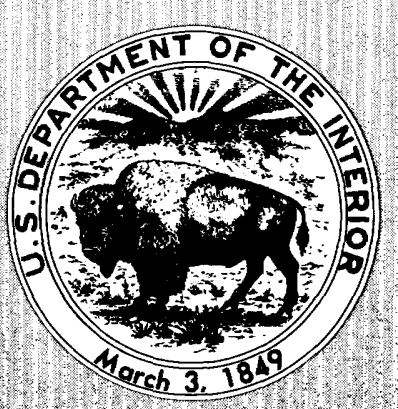

